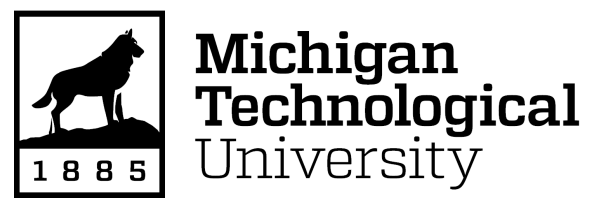

Michigan Technological University Digital Commons @ Michigan Tech

Dissertations, Master's Theses and Master's Reports

2018

ESTIMATION OF DBH USING TREE VARIABLES DERIVED FROM AERIAL LIDAR FOR FORD FOREST, BARAGA, MICHIGAN

Tugay Demiraslan

Michigan Technological University, tdemiras@mtu.edu

Copyright 2018 Tugay Demiraslan

Recommended Citation

Demiraslan, Tugay, "ESTIMATION OF DBH USING TREE VARIABLES DERIVED FROM AERIAL LiDAR FOR FORD FOREST, BARAGA, MICHIGAN", Open Access Master's Thesis, Michigan Technological University, 2018.

https://doi.org/10.37099/mtu.dc.etdr/721

Follow this and additional works at: https://digitalcommons.mtu.edu/etdr

Part of the Forest Management Commons, and the Other Forestry and Forest Sciences Commons 


\title{
ESTIMATION OF DBH USING TREE VARIABLES DERIVED FROM AERIAL LiDAR FOR FORD FOREST, BARAGA, MICHIGAN
}

\author{
By \\ Tugay Demiraslan
}

\begin{abstract}
A THESIS
Submitted in partial fulfillment of the requirements for the degree of MASTER OF SCIENCE

In Forest Ecology and Management

MICHIGAN TECHNOLOGICAL UNIVERSITY

2018

(C) 2018 Tugay Demiraslan
\end{abstract}


This thesis has been approved in partial fulfillment of the requirements for the Degree of MASTER OF SCIENCE in Forest Ecology and Management.

School of Forest Resources and Environmental Science

Thesis Advisor: $\quad$ Dr. Robert Froese

Committee Member: Dr. Curtis Edson

Committee Member: $\quad$ Michael Hyslop

School Dean: Dr. Andrew Storer 


\section{Dedication}

"We have sent you as a spark, you must have returned as a flame." Mustafa Kemal Atatürk (1923)

To Mustafa Kemal Atatürk and the citizens of the country, that he and his generals founded, for supporting me with their taxes. 


\section{Table of Contents}

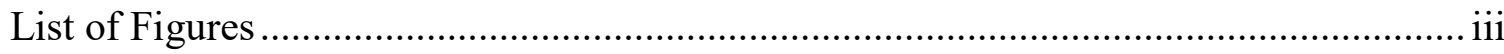

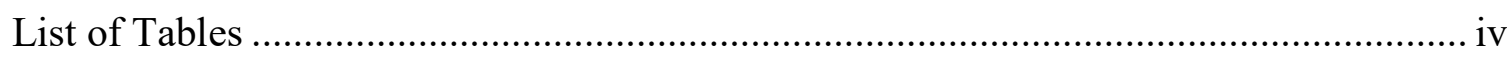

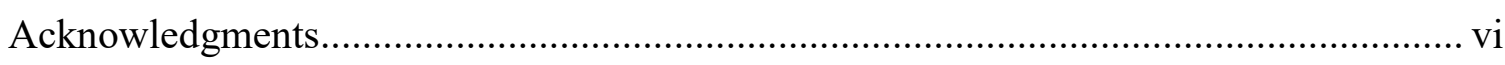

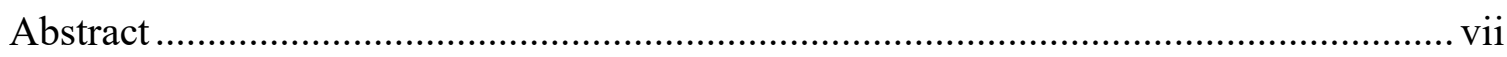

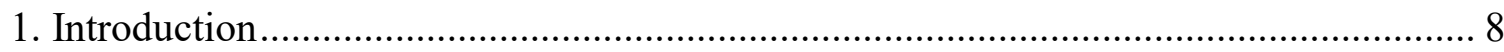

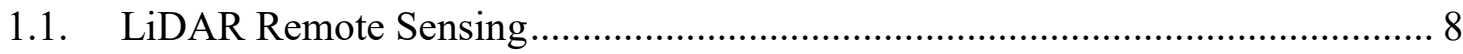

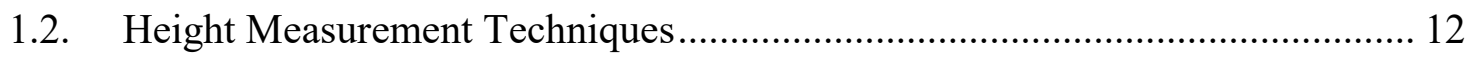

1.3. Statistical Methods for Inventory Modeling .................................................. 14

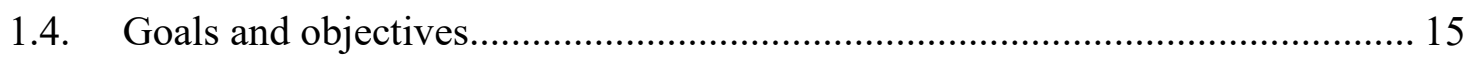

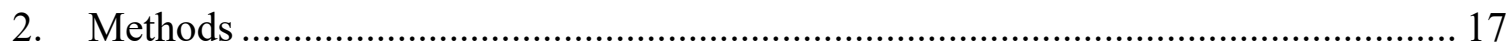

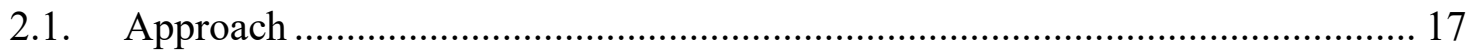

2.2. Height Measurements.......................................................................... 18

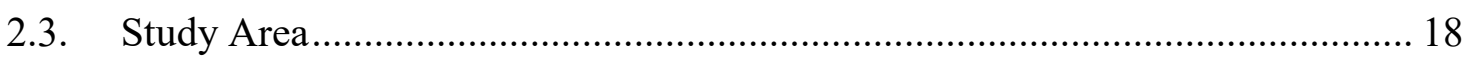

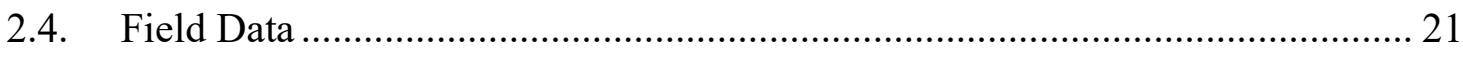

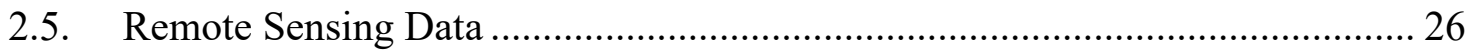

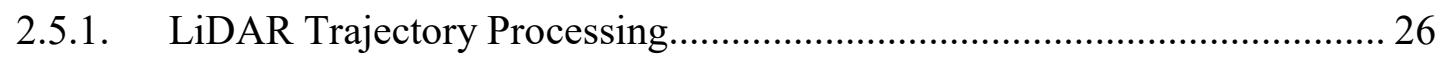

2.5.2. LiDAR Measurement Stages ................................................................. 31

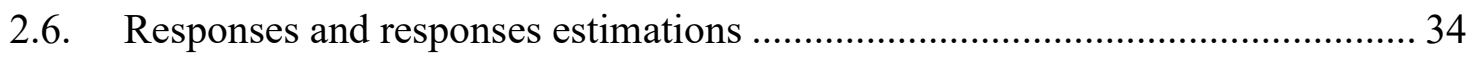

2.6.1. Creating Tree Crown Footprints ................................................................ 34

2.6.2. Estimating Volume \& Increment ............................................................. 35

2.6.3. The estimation of Biomass and Carbon Sequestration ................................ 36

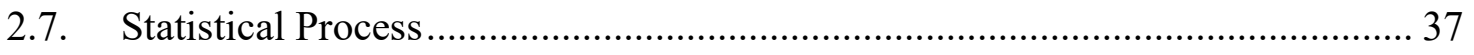

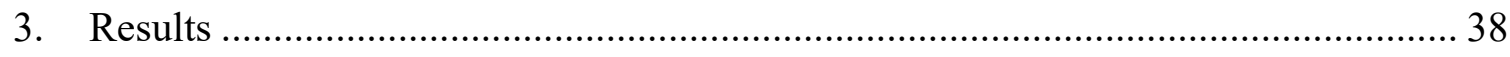

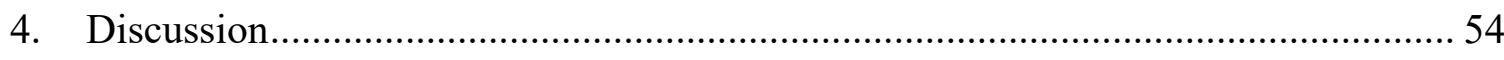

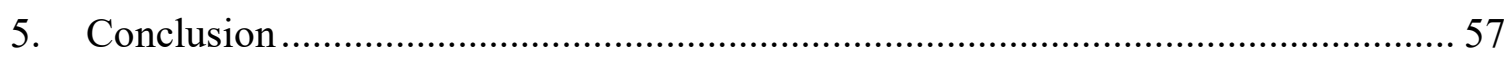

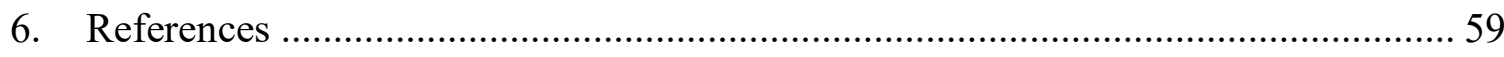

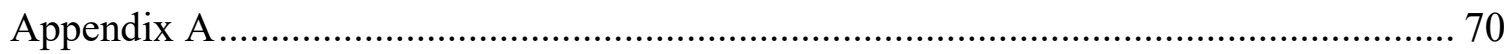

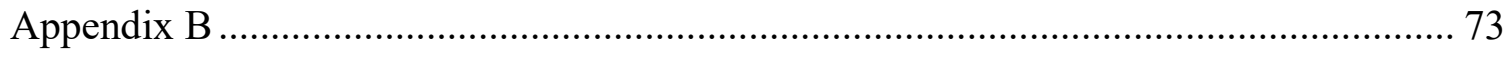

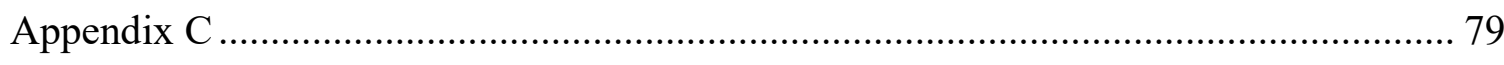


1. Estimated Volume and Biomass by Using Ground Measured Data

2. Estimated Volume and Biomass by Using Predicted DBH Derived from LiDAR

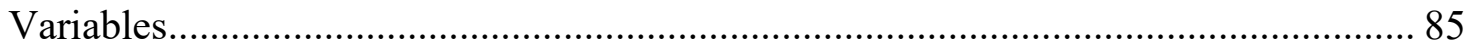

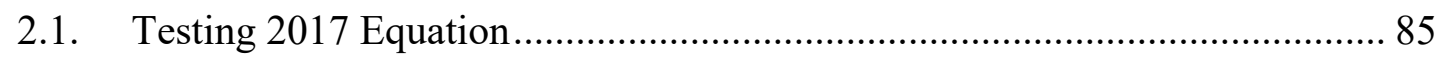

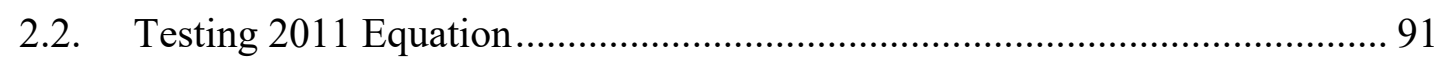

2.3. 6-year time period growth amount …………………..................................... 97

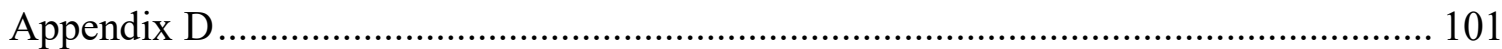




\section{List of Figures}

Figure 1. 3-Dimension description image for pitch, roll, and row. Image source:............ 9 Figure 2. Portrayal of the tangent and sine methods of measuring the height of a vertical

Figure 3. Michigan Upper Peninsula LiDAR Data Collection Area 13

Figure 7. Ground height measurement in spring 2018. Trees are climbed then height to ground measured with tape and height to top measured by pole, from that point............ 24

Figure 8. Tree Species' Distribution on Study Area ................................................... 25

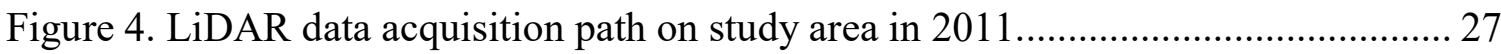

Figure 5. LiDAR data acquisition path on study area in 2017, Image courtesy of Quantum

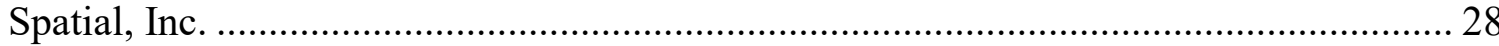

Figure 6. Comparing coordinate systems between Fusion and ArcMap software to make sure about measuring the same tree with field measurements..................................... 34 Figure 9. Regression diagnostics for the 2017 DBH estimation model tested on 2017 data.

Figure 10. Distribution of DBH prediction error based on tree height for 2017 equation tested on 2017.

Figure 11. Distribution of DBH prediction error based on predicted DBH for 2017 equation tested on 2017.

Figure 13. Distribution of DBH prediction error based on tree height for 2017 equation tested on 2011.

Figure 14. Distribution of DBH prediction error based on predicted DBH for 2017

equation tested on 2011.

Figure 15. Regression diagnostics for the 2011 DBH estimation model tested on 2011 data.

Figure 16. Distribution of DBH prediction error based on tree height for 2011 equation tested on 2011.

Figure 17. Distribution of DBH prediction error based on predicted DBH for 2011 equation tested on 2011.

Figure 19. Distribution of DBH prediction error based on tree height for 2011 equation tested on 2017.

Figure 20. Distribution of DBH prediction error based on predicted DBH for 2011 equation tested on 2017. 46

The only copyright needed material is in Figure 21. LiDAR data acquisition path on study area in 2017, Image courtesy of Quantum Spatial, Inc. and the screen capture of the email that illustrates I have permission to use it. 


\section{List of Tables}

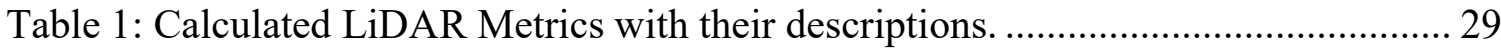

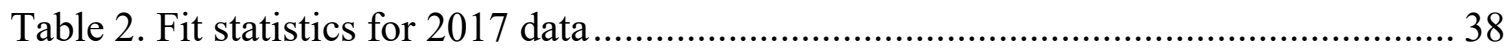

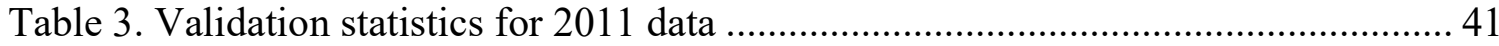

Table 4. Fit statistics for 2011 data............................................................................ 42

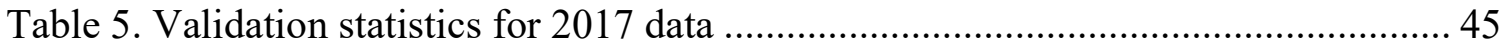

Table 6. R squared and p-value of equations created before taking out the broken tree.. 47

Table 7. R squared and p-value of equations created after taking out the broken tree.... 47

Table 8. Fit statistics for 2017 data after outlier tree was taken out of the dataset.......... 47

Table 9. Validation statistics for 2011 data after outlier tree was taken out of the dataset.

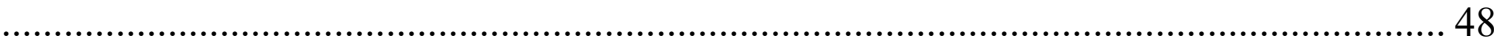

Table 10. Fit statistics for 2011 data after outlier tree was taken out of the dataset........ 48

Table 11. Validation statistics for 2017 data after outlier tree was taken out of the dataset.

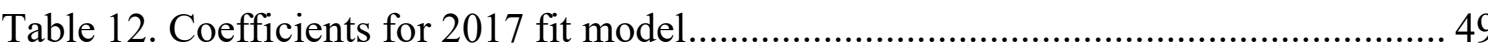

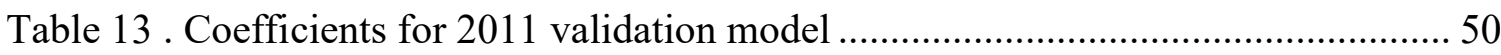

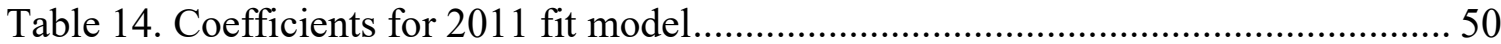

Table 15. Coefficients for 2017 validation model …....................................................... 51

Table 16. Coefficients for hardwood species in 2017 fit model .................................... 51

Table 17. Coefficients for hardwood species in 2011 validation model........................... 51

Table 18. Coefficients for hardwood species in 2011 fit model .................................... 52

Table 19. Coefficients for hardwood species in 2017 validation model......................... 52

Table 20. Coefficients for softwood species in 2017 fit model .................................... 52

Table 21. Coefficients for softwood species in 2011 validation model........................... 53

Table 22. Coefficients for softwood species in 2011 fit model .................................... 53

Table 23. Coefficients for softwood species in 2017 validation model........................... 53

Table 24. Height measurement comparisons between ground and LiDAR for 2017 dataset

Table 25. Height measurement comparisons between laser hypsometer and LiDAR for

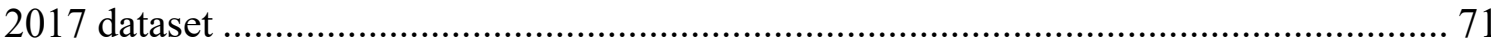

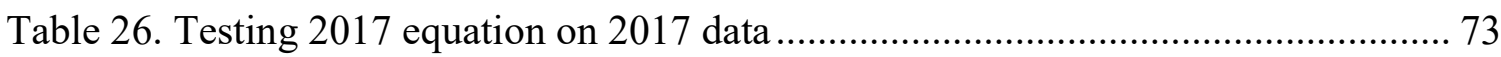

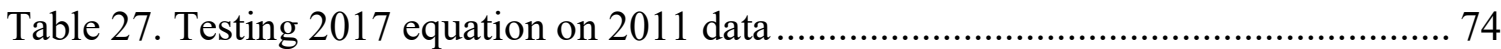

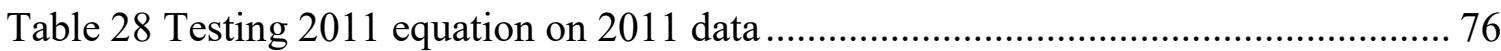

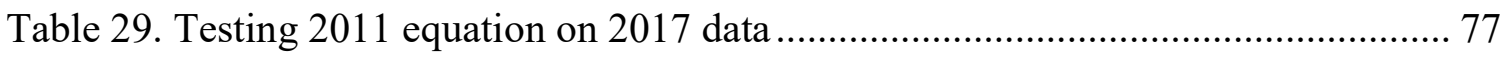

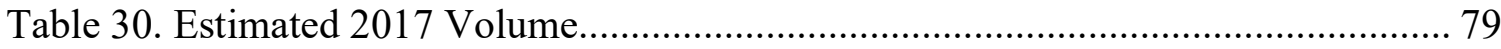

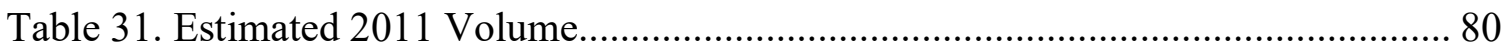

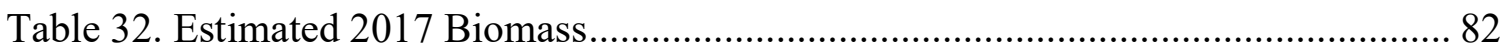

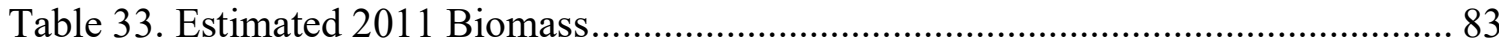


Table 34. Estimated 2017 Volume; 2017 Equation Tested on 2017 Dataset .................. 85

Table 35. Estimated 2011 Volume; 2017 Equation Tested on 2011 Dataset ................... 86

Table 36. Estimated 2017 Biomass; 2017 Equation Tested on 2017 Dataset ................. 88

Table 37. Estimated 2011 Biomass; 2017 Equation Tested on 2011 Dataset .................. 89

Table 38. Estimated 2011 Volume; 2011 Equation Tested on 2011 Dataset .................. 91

Table 39. Estimated 2017 Volume; 2011 Equation Tested on 2017 Dataset .................. 92

Table 40. Estimated 2011 Biomass; 2011 Equation Tested on 2011 Dataset ................. 94

Table 41. Estimated 2017 Biomass; 2011 Equation Tested on 2017 Dataset ................. 96

Table 42. Volume Growth of Single Trees between 2011 and 2017 ........................... 97

Table 43. Dry Biomass Growth of Single Trees between 2011 and 2017 ..................... 99 


\section{Acknowledgments}

First of all, I owe the biggest appreciation to the Republic of Turkey, Ministry of National Education, Ministry of Agriculture and Forest, and General Directorate of Forestry for their financial support during my education.

In addition, I would like to thank my advisor, Robert E. Froese, for guiding, teaching and supporting me. I could not have had my master degree without his help. I also thank my committee members who are Curtis Edson and Mike Hyslop.

Moreover, I want to thank some of my professors, friends, and office mates at Michigan Tech who are Ann Maclean, Chris Miller, Alex C. Rice, Chris Anderson, Robert Richard, and Parth Bhatt.

Furthermore, I would like to thank Houjun Ding, Yanyun Li, Thor Wardell, and Lyndsey Johnston for helping me during my field data collection.

Likewise, I thank to some of my friends for their support. Some of them are Harun Kart, Hasan Salih Kulunk, Aysen Sozen, Cuma Uykun, Zainab Alshoug, Alper Savasci, and last but not least Mustafa Yavuz Cetinkaya.

Finally, I would like to thank my mother Nermin Türkdal, my father Yilmaz Demiraslan, my brother Mustafa Muhammed Demiraslan, and the rest of my family. I could not complete this degree without their support. 


\begin{abstract}
This study implemented LiDAR (Light Detection and Ranging) remote sensing technology and applied ITD (Individual Tree Detection) methods as an approach to estimate some essential tree variables, such as DBH (Diameter at Breast Height), height, volume, and biomass for Ford Forest Research Center in Upper Peninsula, Michigan. There were 34 deciduous ( 1 bigtooth aspen, 9 red oaks, 20 sugar maples, 2 white birches, and 2 yellow birches) and 17 coniferous ( 2 eastern hemlocks, 11 red pines, and 4 white pines) subject tree species. There were two different available LiDAR datasets from the same area that were collected in 2011 and 2017. Height measurements were done at $96 \%$ and $97 \%$ accuracy for hardwood and softwood tree species, respectively.
\end{abstract}

Several other tree variables derived from LiDAR point cloud were used to estimate DBH by using regression analysis for both 2017 and 2011 datasets. Estimation equations were tested on the other dataset. The best-fitted formula was 2017 's, with 0.55 adjusted $\mathrm{R}^{2}$ and less than $0.0001 \mathrm{p}$-values on 2017 LiDAR data while 0.42 adjusted $\mathrm{R}^{2}$ and less than $0.0001 \mathrm{p}$-values on 2011's dataset. Some additional analysis that includes calculating PRMSE (Predicted Root Mean Square Error), BIAS (Mean Error), and MAD (Mean Absolute Difference) have been applied. The equation that was generated by using data from 2017 has -0.57 BIAS for Hardwood and 1.13 BIAS for softwood. That result indicates that the equation has -0.57 centimeters $(\mathrm{cm})$ estimation error for hardwood and $1.13 \mathrm{~cm}$ for softwood on DBH estimations. 


\section{Introduction}

Monitoring aboveground carbon stock plays a significant role in determining its part in the global carbon cycle, predicting how the change in that cycle can be affected by the ratio of land use/land cover change, and estimating the effects of carbon sequestration that results from deforestation (Lefsky et al., 2002). In this case, there are many benefits from using remote sensing including reduced cost, increased accuracy, the ability to measure repeatedly, to cover large areas, etc. Therefore, remote sensing is a solution (Cohen et al., 1996; Running et al., 1999). One of the best existing remote sensing techniques is LiDAR.

\subsection{LiDAR Remote Sensing}

LiDAR is an acronym for Light Detection and Ranging, which is an active remote sensing technology that uses a laser to measure distance. LiDAR can be classified into two basic groups; aerial and terrestrial. The system works by sending thousands of laser pulses per second to the ground and receives the reflectance from the target object by the aerial LiDAR system which is carried by aircraft. With using the travel time of the laser pulse and speed of light, the distance between aircraft and the target is determined. The

formula for this calculation is; $d=\frac{c * t}{2 * n}$

Where:

$\mathrm{d}=$ distance in meters

$\mathrm{c}=$ speed of light in vacuum $(299792458 \mathrm{~m} / \mathrm{s})$ 
$\mathrm{t}=$ time in seconds

$\mathrm{n}=$ refractive index (the ratio of speed of light in vacuum and phase velocity (v) of light in the medium)

The aircraft carries the LiDAR which includes a laser sender and receiver, a Global Navigation Satellite System (GNSS) to determine the exact position where the LiDAR data are collected, and an Inertial Measurement Unit (IMU) to correct some data collection error, which is caused by the weather condition during the flight, for example; Pitch, Roll, and Row.

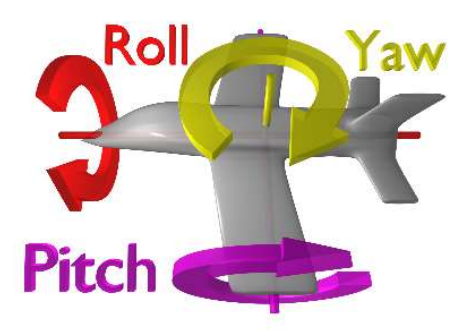

Figure 1. 3-Dimension description image for pitch, roll, and row. Image source:

https://en.wikipedia.org/wiki/Inertial_measurement_unit\#/media/File:Flight_dynamics_w ith text.png; Accessed $<06 / 17 / 2018>$.

LiDAR also plays a significant role in forest inventory by measuring tree heights more accurately and quicker than other remote sensing methods (Ozkal, 2017). For example, LiDAR makes it possible to get multiple returns per pulse which gives a cloud and with post processing each return gives an $(\mathrm{X}, \mathrm{Y}, \mathrm{Z})$ coordinate for each point. Then, by 
selecting the ground returns, a digital elevation model (DEM) can be generated.

Likewise, a digital surface model (DSM) can be generated by displaying the first LiDAR returns. After that, subtracting DEM from DSM derives a canopy height model (CHM).

The LiDAR point clouds become more useful when they are used together with ground data to gain more information about individual trees and stands' structure (Lillesand et al., 2014). Point clouds represent a 3D shape of the feature, and have a set of $X, Y$ and $Z$ coordinates and some other additional attributes, such as tree height and crown diameter. It is possible to use LiDAR for various forest applications, for example; forest inventory (Maack et al., 2016, Hu et al., 2016), forest fire management (Almeida et al., 2016, Hudak et al.,2016), forest management (Wulder et al., 2008, Sasaki et al., 2016), and forest biomass and carbon storage (Hopkinson et al, 2016, Singh et al., 2016). In addition, Dupuy et al., (2013) used high-resolution images and LiDAR to characterize the horizontal structure of a tropical forest canopy. Moreover, using LiDAR for individual tree detection (ITD) gives a significant opportunity to estimate some tree variables, such as diameter at breast height (DBH), by using a number of measured tree variables, for instance, height and crown diameter (Jeronimo et al., 2018).

Predicting DBH from LiDAR is significant for of the following reasons:

1. If height measurements can be done with LiDAR directly to predict DBH then a volume or biomass model can be created to estimate tree volume or biomass. 
2. When LiDAR height combines with tree segmentation then a diameter distribution can be generated, perhaps quantifying forest structure would be possible.

3. Updating forest inventory plot data without visiting the plots may be possible. For example, since 2017 ground data and 2017 LiDAR data are available, then with just another LiDAR data collection after a couple of years, calculating diameter in that year may be done easily.

4. Following (3), finding average diameter growth, volume growth at the tree level and volume growth at the per ha level could be possible.

5. If crown dimensional changes can be done with LiDAR, applying (4) might be very accurate. For example, if crown grows a lot, then DBH probably grew a lot.

6. Since there will be no field collection, errors caused by employees might be reduced. Weather conditions will no longer be a problem for ground data collection.

Hence, the specific objectives of this study are as follows:

- Illustrate what variables derived from LiDAR dataset are the most powerful to estimate DBH by using ITD method.

- Demonstrate how accurate these estimations are by comparing with groundmeasured metrics. 


\subsection{Height Measurement Techniques}

Tree height is one of the most significant variables for predicting tree biomass and volume; however, forests, which have tall, wide crowns and dense canopies, causing measurement difficulties (Larjavaara and Muller-Landau, 2013).

To measure tree heights from the ground, a variety of techniques have been used (Clark \& Clark 2001; Chave 2005). The oldest method among them may be climbing the tree. The requirement for this measurement is at least two people since the climber might not see the top of the tree from directly below. In that case, the second person should step back from tree until they have a clear view to decide the highest point of the tree. When the well-equipped climber reaches their position on the tree, they release the measuring tape to the ground and pulls up the height pole to the peak of tree. The second person tells them to stop when the pole reaches the highest point of tree and climber reads the value on the pole. Then the second person reads the value on the measurement tape; combines both pole and tape values and records it. The downsides of this method are technicians' errors and time. For example, based on the experience in this study, measuring a tree can takes 45 minutes to 1 hour. That would be an issue for large area studies.

Another easier way to make this measurement is the tangent method. The principles of this manner are measuring angles ( $\alpha$ and $\beta$ in Figure 2$)$ from horizontal by using a clinometer and integrating these with either horizontal distance measurements or an angle to a known length pole's measurements (Korning \& Thomsen 1994). 


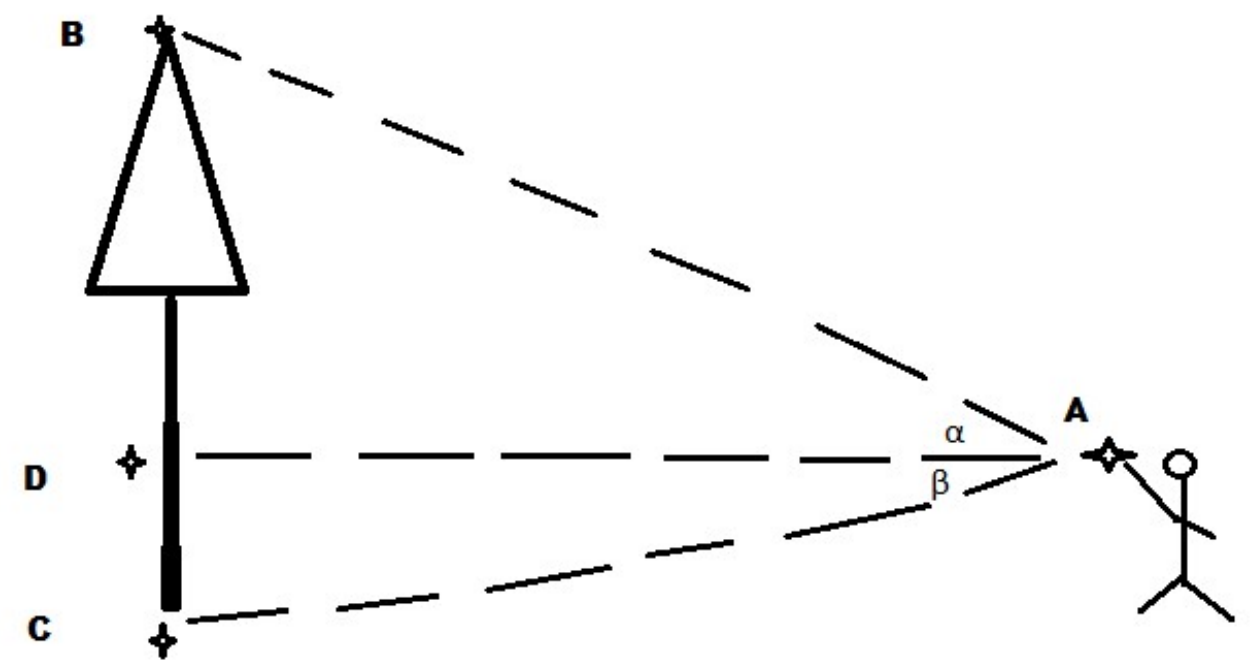

Figure 2. Portrayal of the tangent and sine methods of measuring the height of a vertical tree where $\mathrm{BD}=\tan (\alpha) * \mathrm{AD} ; \mathrm{CD}=\tan (\beta) * \mathrm{AD}$ and as a result, the total height $\mathrm{BC}=\mathrm{BD}+\mathrm{CD}$.

Because measurement of distance between clinometer and tree requires a tape and recording two measurements for one tree, this method is time-consuming. Thereby, laser rangefinders have been used to perform the same measurements more efficiently.

A laser hypsometer uses a rangefinder to measure tree heights. It sends laser pulses to the tree to determine the distance from the hypsometer, to the top and base of the tree to estimate its height by combining tangent and sine methods. The observer has to be far enough from the tree to apply this method without random errors. Based on Goodwind's (2004) study, the angle from horizontal to the top should be smaller than $45^{\circ}$. That means the technician should be standing at a distance which nearly equals one tree height. The main justification under this recommendation is that the closer the technician is to the 
tree, the greater the deviation when the tree is leaning (Larjavaara and Muller-Landau, 2013). However, being at the correct position might not be enough to avoid the bias in some cases, such as if the forest density is high and tree canopies are concentric.

Additionally, high growth under canopy can cause the issue of difficulty in targeting the bottom of the tree (Bragg, 2014)

\subsection{Statistical Methods for Inventory Modeling}

To create models of inventory data, a wide range of statistical methods have been used (Brosofske et al., 2014). The main goal of these inventories is determining standing trees' volume or value in a selected area as consummately as possible without wasting time and money (Avery and Burkhart, 2002). One of the oldest inventory techniques for groundbased data is called 'design-based'. The idea behind this method is sampling the study area by plots or strips, doing the necessary measurements on subject trees within a sampled area at the stand level, and generating forest level statistics. To summarize, estimating attributes at the per-hectare level is possible using design-based inventory.

Another method for forest inventory is known as model-based. This is a technique that uses the ground measured data to create a model and inferences from the model (Schreuder et al., 1993). This is a way to find the correlation between ground measurement data and measurements from remote sensing instruments. One of the most accurate model-based methods is linear regression. Using stepwise selections in software such as R Studio enables us to find the best fitting model which defines the dependent variable using other independent components. For instance, Andersen, McGaughey, and 
Reutebuch (2005) generated a forest canopy model by using stepwise regression selection. The $\mathrm{R}^{2}$ values they found were higher for canopy base height, crown bulk density, and canopy height. On the other hand, like all statistical methods, regression has a downside, such as decreased degrees of freedom when the number of independent variables in the regression is increased (Pandey and Bright, 2008). Hence, some problems may occur if regression applies to a small dataset.

The other way to perform forest inventory is using LiDAR data. If the LiDAR dataset is combine with design-based sample plots, almost all required tree variables can be determined on a computer. Nevertheless, measuring DBH and determining tree species is not possible with LiDAR yet. In this case, needed ground measurements can be sampled, and a correlation between LiDAR and ground data can be found with linear regression models. When the reliability of the model is proved, predictions can be made. After that, by adding up all of the individual tree values, a forest inventory can be generalized.

\subsection{Goals and objectives}

Foresters have always aimed for accurate and quick tree height measurements. For that purpose, quantification demonstrated hypsometers (e.g., Schlich 1895, Mlodziansky 1898, Graves 1906) were developed more than a hundred years ago. The main idea behind these tools was using angles and distance (Graves 1906) to estimate the total height of trees. Since the application of these tools was easy and practical, they became

the most dominant tree height measurement methods until some accuracy problems were reported by foresters (Bragg, 2014). With the invention of LiDAR developed in 1960, a 
more accurate method was found. Yet, it was not accurate enough for measuring trees until Global Positioning System (GPS) equipment and inertial measurement units (IMUs) became commercially available in the late 1980s (Gregersen, 2016).

Due to these technological developments, the goal of this research is determine if LiDAR can detect tree height growth in a small time period. To be able to proceed, the questions below were answered respectfully:

1. How accurate is LiDAR-derived height compared to ground measured height?

2. If the result shows LiDAR is effective at measuring height, then it can be assumed that the measuring height from historic LiDAR can be reliable as well. Then the question is: can height growth be estimated using LiDAR?

3. How accurately can DBH predictions be performed from LiDAR metrics? Ideally, some models can be fitted and validated against future or past measurements.

After answering the questions above, ultimately, these models will enable us to predict individual-tree DBH using measured heights and, subsequently, predict volume and biomass. With repeated LiDAR acquisitions, biomass or volume growth and inventory can also be derived. 


\section{Methods}

\subsection{Approach}

Estimating a component that is hard to measure from another easy to measure component is a common method in many disciplines. Likewise, in Forestry, since measuring tree heights is harder, more time consuming and expensive than measuring $\mathrm{DBH}$, foresters have historically generated equations that predict heights from diameter. However, with the development of remote sensing technology, such as aerial photos and LiDAR, measuring tree heights is getting easier. Besides height, many other standard forest inventory metrics; for example, merchantable volume, density, and basal area, have become possible with ITD (Edson and Wing, 2011).

This study has focused on answering the following questions for Michigan Technological University (MTU) Ford Center research forest.

1. Is estimating DBH from other measured tree variables by using LiDAR ITD technique possible?

2. What variables that are derived from LiDAR data are the best to make a DBH estimation?

3. How accurate are these DBH predictions?

By using the GPS points of collected ground data, measured trees were found in LiDAR data and measurements were executed on a computer. Afterward, to find the best fitting 
model on predicting DBH from other variables, $\mathrm{R}^{2}$ and $\mathrm{p}$-values were considered for regression analysis.

ArcGIS 10.5.1, Fusion 3.60, and RStudio Version 1.0.153 software packages were used in this study.

\subsection{Height Measurements}

Three different height measurement methods were used, these include ground (climbing) measurements, a laser hypsometer and LiDAR.

\subsection{Study Area}

The study area is a portion of the Ford Forest, which is a research forest that belongs to Michigan Technological University (MTU). This location was chosen since the LiDAR data was already collected and available for two different dates. The LiDAR data covers nearly 3,858 ha in northwest Michigan and is located between $46^{\circ} 39^{\prime} 05^{\prime \prime}-46^{\circ} 37^{\prime} 34^{\prime \prime}$ the northern latitude and $-88^{\circ} 33^{\prime} 10^{\prime \prime}--88^{\circ} 28^{\prime} 21^{\prime \prime}$ the east longitude in Geographic Coordinate System.

Hilly glacial till plains and moraines made up ambient habitat on the Ford Forest (Gebuhr, 2013). Average annual rainfall is $87 \mathrm{~cm}$, annual snowfall averages $381 \mathrm{~cm}$, and yearly range of temperature covers between $-9.8^{\circ} \mathrm{C}$ and $17.4^{\circ} \mathrm{C}$ (Gebuhr, 2013). The range of elevation for the study area is $411-448 \mathrm{~m}$. Dry to mesic silt loams which are nutrient rich that are found in a northern hardwood overstory, and nutrient-poor xeric sandy glacial outwash plains that dominated by jack pine canopy constitutes the soil types (Gebuhr, 2013). 


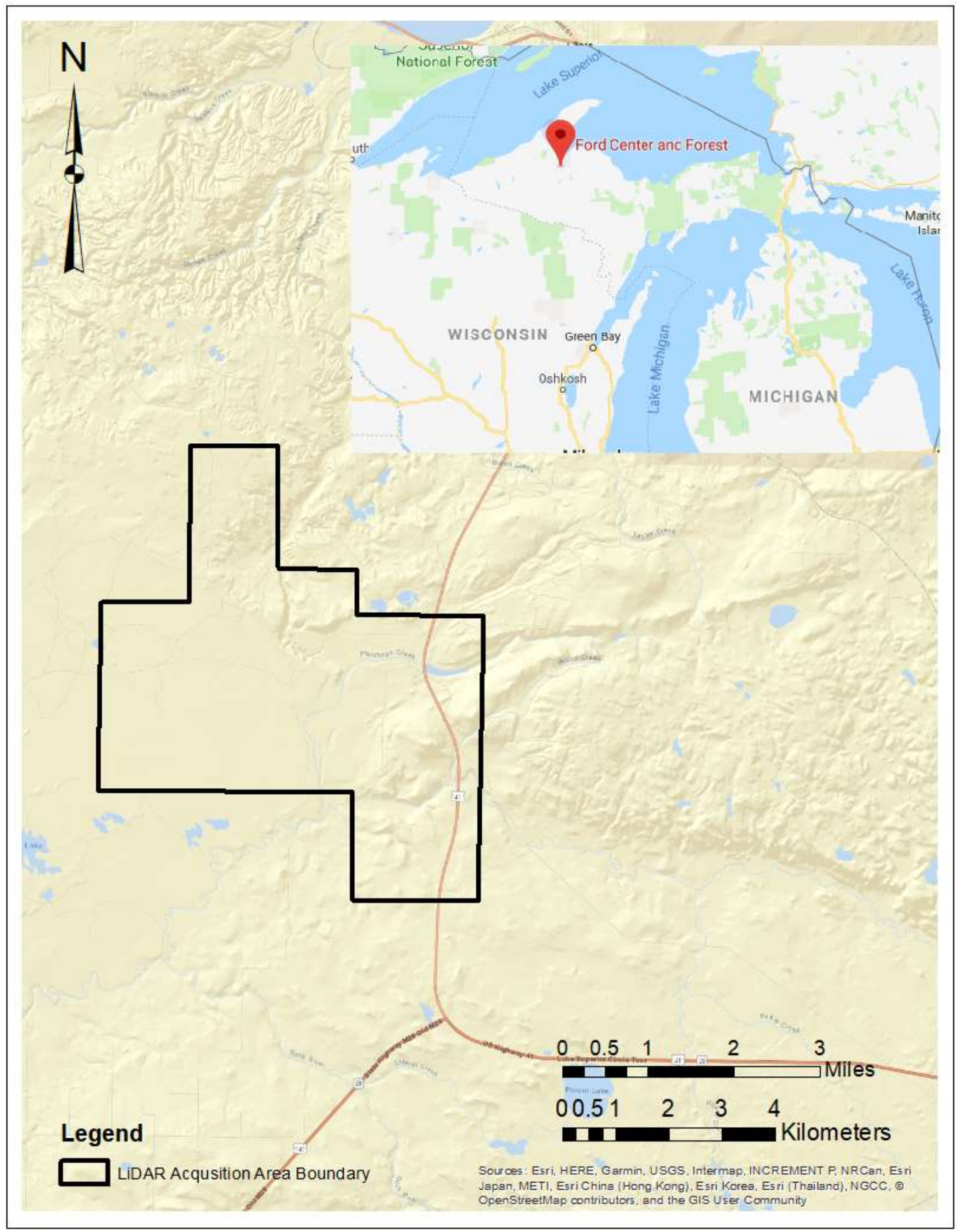

Figure 3. Michigan Upper Peninsula LiDAR Data Collection Area 
According to MTU's School of Forest Resources and Environmental Science, the forest area is $\sim 1,497$ ha. Jack pine dominates the sandy glacial outwash area. Also, alluvial soil that around the Sturgeon River is suitable for upland northern hardwoods, and conifers like hemlock and black spruce. For more information, see http://www.mtu.edu/forest/fordcenter/forest/.

The major species in the study area can be separated into two classes, which are hardwood (deciduous) and softwood (coniferous). Hardwoods include: sugar maple (Acer saccharum), yellow birch (Betula alleganiensis), red maple (Acer rubrum), ironwood (Eastern hophornbeam, Ostrya virginiana), black cherry (Prunus serotina), bigtooth aspen (Populus grandidentata), trembling aspen (Populus tremuloides), white birch (Betula papyrifera), northern red oak (Quercus rubra), basswood (Tilia americana), american elm (Ulmus americana), black ash (Fraxinus nigra), white ash (Fraxinus americana). Softwoods are; eastern hemlock (Tsuga canadensis), balsam fir (Abies balsama), eastern white pine (Pinus strobus), red pine (Pinus resinosa), jack pine (Pinus banksiana), white spruce (Picea glauca), black spruce (Picea mariana), tamarack (E. larch, Larix laricina), northern white cedar (Thuja occidentalis) (Quantum Spatial, Inc., 2017). The study area has been exposed to heavy selective cutting silvicultural practices at the beginning of the century (Meteer, 1966), but that application has been replaced with regulated selection harvesting, such as single- tree selection of late (Neuendorff, 2007). 


\subsection{Field Data}

The field data were collected during fall 2017 and spring 2018, before leaf break. Study plots were distributed by a simple random sampling method in the field for 20 trees. With post-processing in the Pathfinder Office software, coordinates for determined plots uploaded to a Trimble GeoXH 6000 global positioning system receiver to establish the plot centers. The horizontal accuracy was $1.00 \mathrm{~m}$ or less.

The tallest tree of each plot was selected. Necessary tree inventory metrics (i.e. species, diameter at breast height $(1.3 \mathrm{~m})(\mathrm{DBH}>10 \mathrm{~cm})$, and height $)$ were collected at each plot.

For the rest of the subject trees, various places were visited, and trees that have different topographic characteristics like elevation and different species were chosen to sample arbitrarily. Because of high-level snow on the ground, doing the rest of the height and DBH measurements were not possible. Section 12 was selected as an alternative study site for its accessibility. Since the section is small and has different types of topography and tree species, arbitrary selection was applied rather than creating new plots. Then, like the sampled plot trees, essential tree variables were collected.

Two different methods for measuring height were used climbing and using a Haglof Vertex laser VL400 hypsometer.

After data collection was completed, the collected GPS points, height, and DBH measurements were transferred into ArcMap 10.5.1 software to create a shapefile that indicates all tree attributes. 
In summer 2018, the trees were re-visited and two increment cores were collected from each tree. Cores were taken within $20 \mathrm{~cm}$ of breast height and at approximately 120 degree separation. These were inserted into straws to retain their moisture and avoid shrinkage before they got measured. Each was labeled with tree ID numbers and core numbers as $\mathrm{C} 1$ or $\mathrm{C} 2$.

Collected cores were taken to the lab, placed on a wooden plate, which have canals on it to insert the cores, put under the microscope, which connected to a computer, and they were measured using the microscope. However, some of the cores were in bad shapes to see the separation between growth years. Therefore, their length were measured before and after they become dry to measure to test for shrinkage, and it found a small amount to consider. Then, they placed and glued on the wooden plate and sanded. After that, the differences between age rings were become noticeable and they were measured as mentioned above. The last 10 age circles were measured, yet only the last 6 measurement values were used to predict the growth amount since 2011.

All the core measurements were done without bark. However, since all the ground measurements were done with bark, bark ratios for each tree types were found and added to the core measurements. Thus, the closest estimations to the real measurements were derived. The formula for DBH with bark estimation was

$$
\begin{gathered}
\mathrm{DOB}_{2011}=\left[\frac{\mathrm{DOB}_{2017}}{\mathrm{BR}}-\Delta D I B_{2011}\right] * B R \\
B R=\frac{\mathrm{DOB}_{2017}}{\mathrm{DIB}_{2017}}
\end{gathered}
$$




$$
\mathrm{DIB}_{2017}=\frac{\mathrm{DOB}_{2017}}{\mathrm{BF}}
$$

Where:

$\mathrm{DOB}_{2011}=2011$ 's diameter outside of the bark

$\mathrm{DOB}_{2017}=2017$ 's diameter outside of the bark that measured in the field

$\mathrm{BR}=$ Bark ratio

$\Delta \mathrm{DIB}_{2011}=$ The average of two different increment cores' last 6 age rings measurements value

$\mathrm{DIB}_{2017}=2017$ 's diameter inside the bark which is $\mathrm{DOB}_{2017} * \mathrm{BF}$

$\mathrm{BF}=$ Bark factor is the ratio of DIB to DOB at given tree height, which differs by species.

Bark factors for red pine was derived from Fowler and Damschroder (1988), oaks from

Fowler et al. (1997), hemlocks from in Kozak and Yang (1981), and the remaining species from Fowler et al. (1999). 


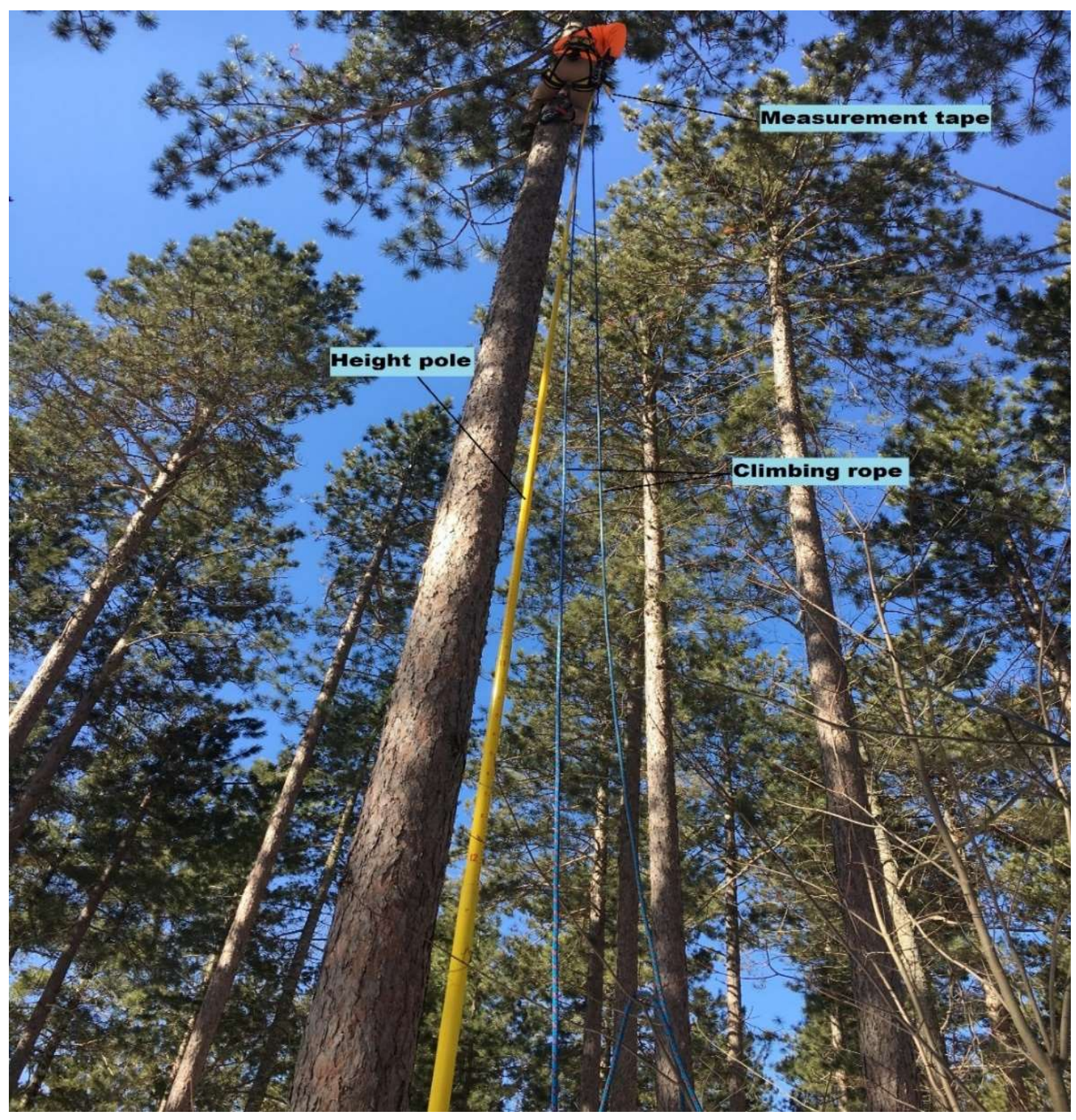

Figure 4. Ground height measurement in spring 2018. Trees are climbed then height to ground measured with tape and height to top measured by pole, from that point. 


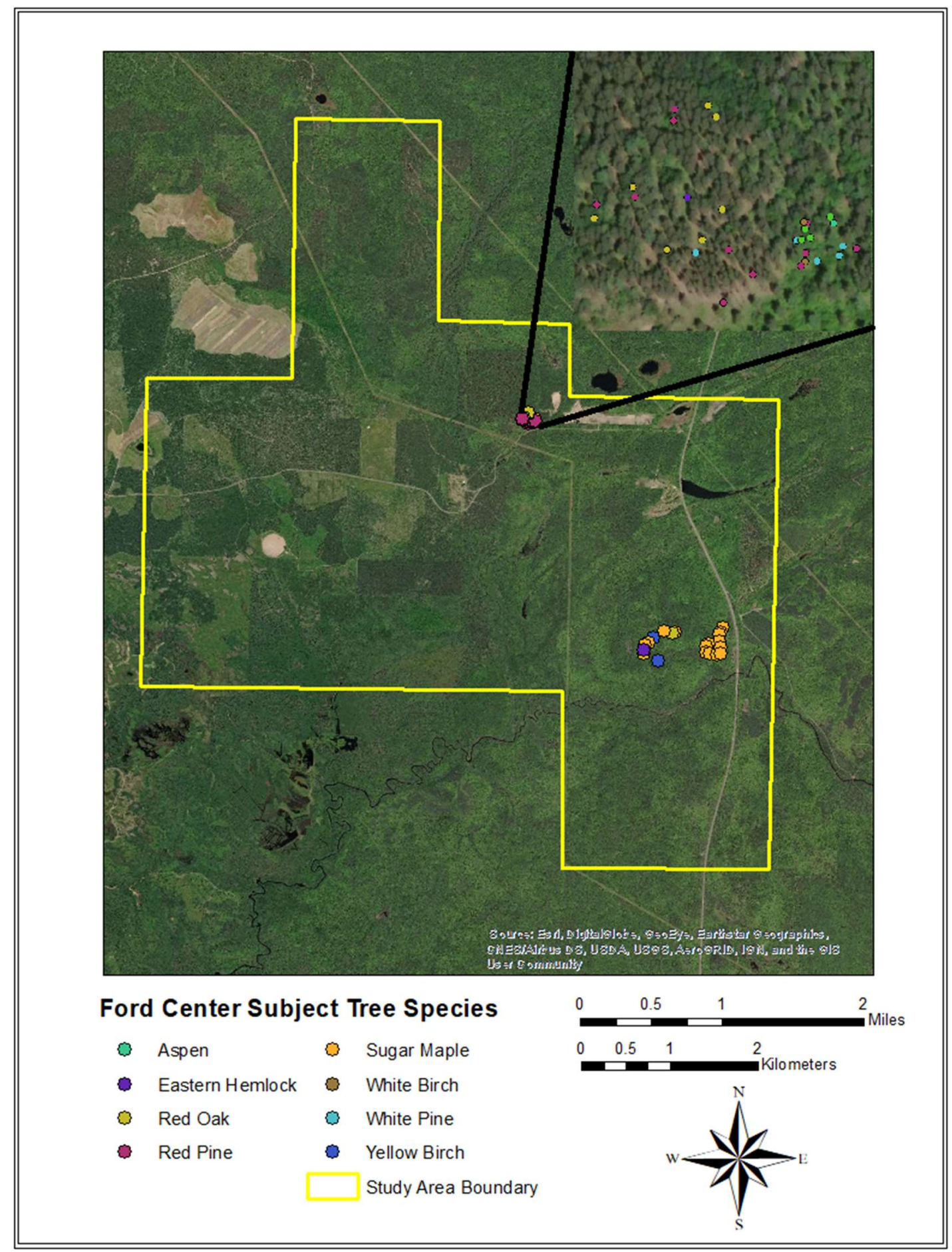

Figure 5. Tree Species' Distribution on Study Area 


\subsection{Remote Sensing Data}

Two different LiDAR data were collected across the study area. The first collection occurred in June 2011 by Aerometric, Inc (Sheboygan, WI USA) using a Riegl Q680I airborne laser scanner. The flight was performed at $457 \mathrm{~m}$ sensor altitude and sixty knots ground speed. The frequency of LiDAR pulses was $400 \mathrm{kHz}$, and the point density was eighteen pulses per square meter (psm), with recorded nine or fewer returns per pulse. The data were classified into two groups, non- vegetative and vegetative (Gebuhr, 2013).

\subsubsection{LiDAR Trajectory Processing}

The airborne positioning was based on MIBX, which is the four character ID code for the Continuously Operating Reference Station (CORS) in Baraga, MI. CORS provides Global Navigation Satellite System (GNSS) data consisting of carrier phase and code range measurements in support of three-dimensional positioning, meteorology, space weather, and geophysical applications throughout the United States, its territories, and a few foreign countries. 


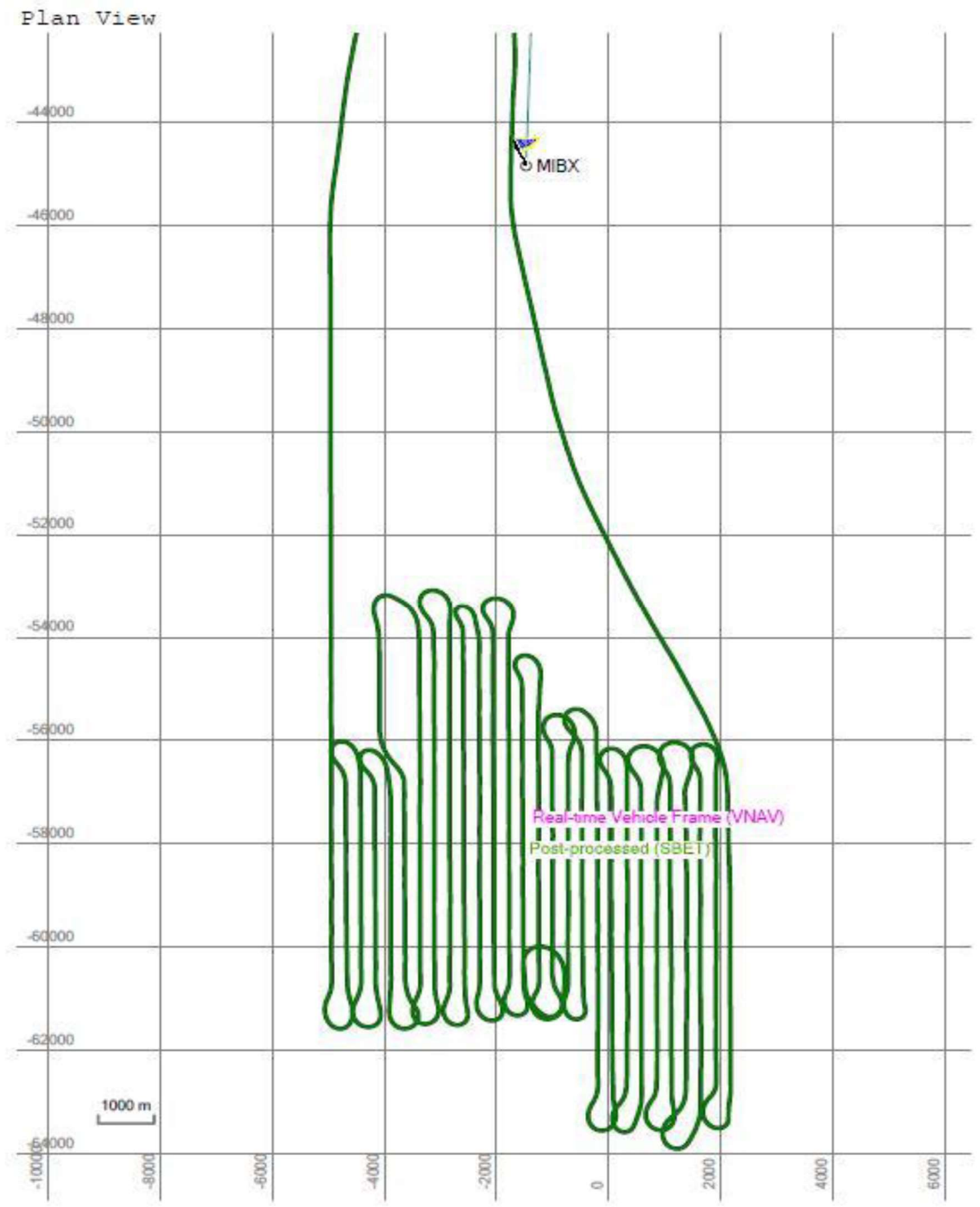

Figure 6. LiDAR data acquisition path on study area in 2011. 
The other data survey was completed on July 15, 2017, by Quantum Spatial. A Piper PA31 aircraft was used to fly and the Optech Orion H300 sensor mounted in it. The altitude of the airplane was $750 \mathrm{~m}$ and the speed was 130 knots. The laser pulse rate was $300 \mathrm{kHz}$ with more than 20 pulses per square meter (Quantum Spatial, Inc., 2017).

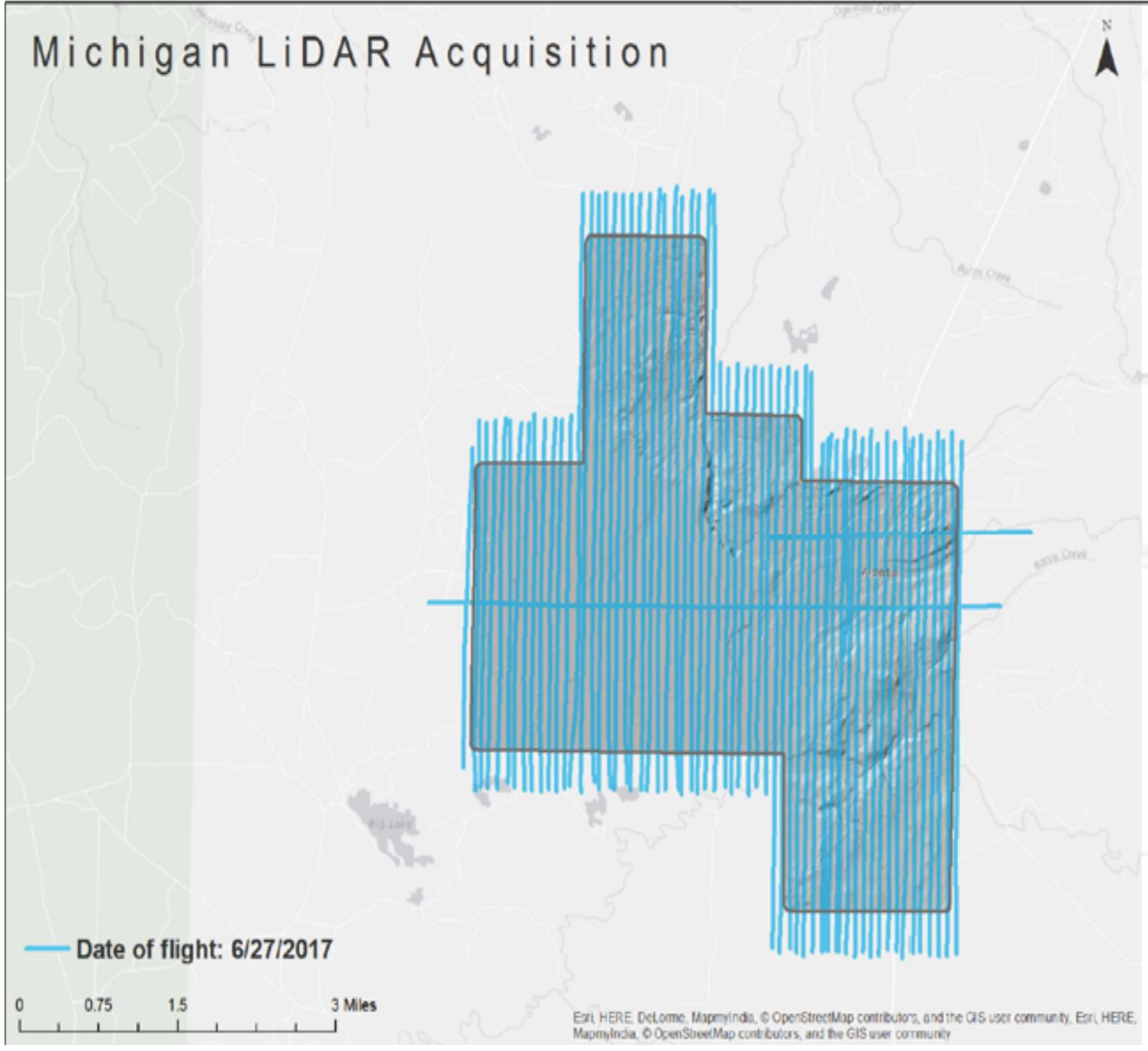

Figure 7. LiDAR data acquisition path on study area in 2017, Image courtesy of Quantum Spatial, Inc. 
After data delivery, FUSION Version 3.60 software package (McGaughey, 2016) was used to process the LiDAR data. By using bare earth (non-vegetative) returns, I created a 2-meter horizontal spatial resolution digital elevation model (DEM). Following DEM creation, LiDAR data were clipped to 52 plots and each of them had $25 \mathrm{~m}$ diameter around the coordinate points of measured trees on the field. The purpose of that step was making the process faster (the smaller the data, the faster the process) and being able to recognize and measure the same tree in Fusion software. Height aboveground was estimated by subtracting the DEM elevation value from the return elevation value for each LiDAR return. The number of vegetation structure metrics (Table 1) described by LiDAR were calculated for each clipped plot.

Table 1: Calculated LiDAR Metrics with their descriptions.

\begin{tabular}{ll}
\hline Metric Name & Metric Description \\
\hline Total return count & Total number of returns (bare earth and above) \\
Total return count above 3.00 & Total number of returns above $0.15 \mathrm{~m}$ \\
Return \# count above 3.00 & Total number Return \# above $0.15 \mathrm{~m}$ \\
Elev minimum & Minimum Height \\
Elev maximum & Maximum Height \\
Elev mean & Mean Height \\
Elev mode & Mode Height \\
Elev stddev & Standard Deviation of Heights \\
Elev variance & Variance of Heights \\
Elev CV & Coefficiency of Variation of Heights \\
Elev IQ & Interquartile Distance of Height \\
Elev skewness & Skewness of Heights \\
Elev kurtosis & Kurtosis of Heights
\end{tabular}


Elev AAD

Elev L\#

Elev L CV

Elev L skewness

Elev L kurtosis

Elev P\#

Int minimum

Int maximum

Int means

Int mode

Int stddev

Int variance

Int $\mathrm{CV}$

Int IQ

Int skewness

Int kurtosis

Int AAD

Int L\#

Int L CV

Int L skewness

Int L kurtosis

Int P\#

$\%$ of first returns above height break

$\%$ of all returns above height break

(All returns above height break) /

(Total first returns) * 100

First returns above height break
Average absolute deviation from the mean of Height

L\#-moment of Height

L-moment Coefficient of Variation of Height

L-moment Skewness of Height

L-moment Kurtosis of Height

Heights \#th Percentile

Minimum Intensity

Maximum Intensity

Mean Intensity

Mode Intensity

Standard Deviation of Intensity

Variance of Intensity

Coefficient of Variation of Intensity

Interquartile Distance of Intensity

Skewness of Intensity

Kurtosis of Intensity

Average absolute deviation from the mean of Intensity

L\#-moment of Intensity

L-moment Coefficient of Variation of Intensity

L-moment Skewness of Intensity

L-moment Kurtosis of Intensity

\#th Percentile of Intensity

Percentage of first returns above canopy height

Percentage of all returns above canopy height

Percentage of canopy cover

Number of first returns above canopy height 
All returns above height break

$\%$ of first returns above mean

$\%$ of first returns above mode

$\%$ of all returns above mean

$\%$ of all returns above mode

(All returns above mean) /

(Total first returns) * 100

(All returns above mode) /

(Total first returns) * 100

First returns above mean

First returns above mode

All returns above mean

All returns above mode

Total first returns

Total all returns
Number of all returns above canopy height

Percentage of first returns above mean height

Percentage of first returns above mode height

Percentage of all returns above mean height

Percentage of all returns above mode height

Percentage of mean height cover

Percentage of mode height cover

Number of first returns above mean height

Number of first returns above mode height

Number of all returns above mean height

Number of all returns above mode height

Total number of first returns

Total number of all returns

\subsubsection{LiDAR Measurement Stages}

Based on the Fusion Exercise Tutorial 5: CALCULATE LIDAR METRICS

(McGaughey, 2016), the following steps were followed to estimate the individual tree heights in Fusion software:

1. A reference image and a DEM were created and the field measurement plots were clipped and used in the Fusion software.

2. Underneath the Sample Options...,

2.1. Sample shape: Fixed circle

2.2. Sample size: 25 (diameter (m)) 
2.3. Options: Subtract ground elevation from each return is checked

2.4. Options: Snap sample points to nearest point of interest (POI) point is checked 2.5. Options: Show POI layers in sample image is checked

2.6. Bare earth filter: Exclude points close to the surface is checked

2.7. Bare earth filter: Tolerance set as $\mathbf{1}$ (the tolerance is the distance from the surface in the same units used for LIDAR data elevations)

3. Then, by clicking $\mathbf{O K}$ at the bottom left, Sample Options... window closed.

4. After that, check marks were inserted to make Plot mode and Display sample options on in the Fusion main window.

5. Next, the LiDAR Data Viewer (LDV) window was popped up with the subset of data by clicking on first plot in the main Fusion viewer.

6. To activate Measurement marker in LDV, F9 key has been hit on the keyboard and a cylinder was showed up.

7. The cylinder moved around the plot by using the combination of ctrl+ right mouse click+ movements until the tree found.

8. The diameter of the cylinder was changed to fit the tree with the help of shift+ ctrl+ right mouse + movements combination.

9. Using the ctrl+ left and right arrows on the keyboard modified the orientation of the ellipse.

10. The cylinder was arranged as larger than the tree crown to be able to use F key since it fits the cylinder to the crown. 
11. After these settings, the measurements have been started by entering Tree identifier on the Tree Measurements window. Trees were identified depending upon plot numbers in this case.

12. Location of the trees was set by clicking the adjacent Set button.

13. To make sure that the selected tree is the one that measured on field, the coordinates of trees in ArcMap software's attribute table were checked (see Figure 6) for every single tree. Analogously, the photographs of measured trees, which were taken on the field, were checked for each plot and decided based on their appearance.

14. Elevation at tree bases was found by typing "I" (lower case L) and by clicking on the Set button.

15. To find the Total height, "h" was typed and Set button was clicked.

16. Height to crown bases was found by scrolling down and clicking adjacent Set button.

17. By clicking Set button adjacent to Crown diameter; Minimum, Maximum, and Crown rotation values were set.

18. Comments (in this study, there was only one crucial situation) were added.

19. Browse button was hit and a new CSV file was created.

20. By clicking to Set tree parameters button, the measurements were saved on the CSV file that just created.

21. To move to the next plot, the plot area was clicked on Fusion main viewer and it appeared on the LDV window.

22. The steps, which are above were repeated for each plot. 


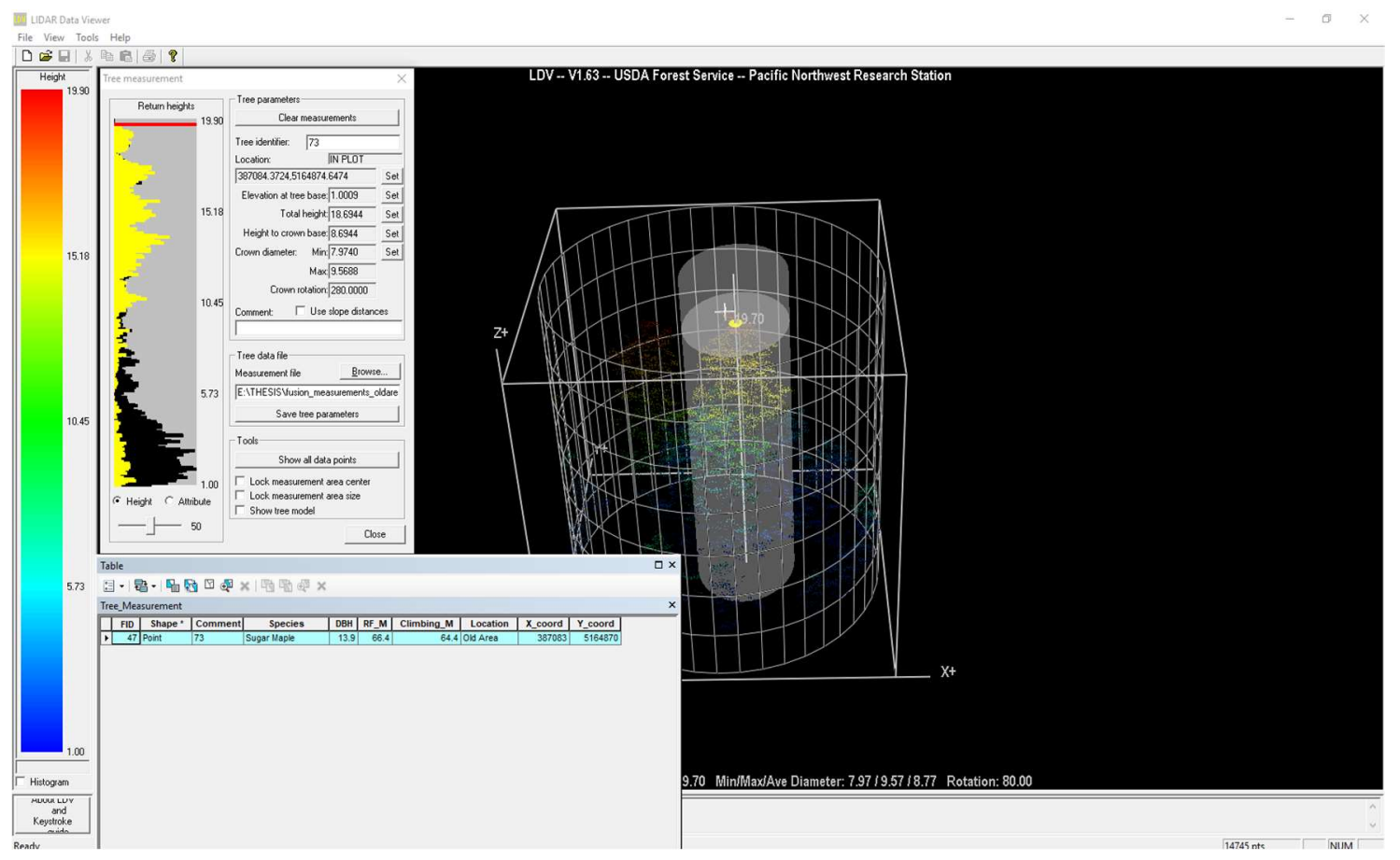

Figure 8. Comparing coordinate systems between Fusion and ArcMap software to make sure about measuring the same tree with field measurements.

\subsection{Responses and responses estimations}

\subsubsection{Creating Tree Crown Footprints}

Two canopy height surfaces/models (CHM) were generated by using LiDAR point clouds for both 2017 and 2011 separately in Fusion software. Afterward, those images were imported into ArcMap and the collected GNSS point shapefile for each individual tree was overlayed. Then, two different polygon shapefiles were created by drawing polygon features around tree canopies. The individual tree crown areas were calculated in the attribute table and exported as an Excel file to use in regression analysis. Because this 
variable was not derived automatically from LiDAR measurements, it is not placed in Table 1.

\subsubsection{Estimating Volume \& Increment}

A standing tree volume estimator used by the Forest Service named The National Volume Estimator Library (NVEL) was used to predict the volume of individual trees as an Excel function. The formula that was used within the NVEL was

$=$ CalcMerchCubic $(9,7$, "901DVEE833", DBH, TotalHeight, MaximumCrownDiameter)

where:

calcMerchCubic: The name of function that calculates the merchantable cubic foot volume of the tree,

9 (The first digit in the bracket): Forest region code,

7 (The second digit in the bracket): Forest number,

901DVEE (In the quotation mark): Volume equation number, which is Gevorkiantz Board Foot Equation (Gevorkiantz and Olsen, 1955),

833 (The last three digits in the quotation mark): Tree species code.

The problem with volume predictions using this tool is that the $\mathrm{DBH}$ values under 10 (ten) inches were not included in the tool. Hence, the volume of the trees under ten inches in 2011 were considered as 0 (zero). When these trees diameter growth reached over ten 
inches in 2017, the value that seems like 6 years volume growth is actually the total volume of the tree. These trees have been marked in Appendix C-3 tables.

\subsubsection{The estimation of Biomass and Carbon Sequestration}

The National Biomass Estimator Library (NBEL), was used to estimate standing tree aboveground biomass. NBEL is open source and was created by the Forest Management Service Center (FMSC) at USDA Forest Service (Wang, 2014). It is a synthesis that contains published or unpublished biomass equations in the US developed by the Forest Management Service Center (FMSC) (Wang, 2014). If there is a default equation for the subject region, NBEL uses it automatically. In contrary, it uses stem cubic volume to calculate biomass and Component Ratio Method (CRM) (Heath 2009) to generate dry biomass prediction.

The formula that was used for prediction was

=bmAboveGroundTotal $(9,7,1,833, \mathrm{DBH}$, Total height)

where;

bmAboveGroundTotal: Biomass of whole tree (aboveground),

9 (The first digit in the bracket): Forest region code,

7 (The second digit in the bracket): Forest number,

1 (The third digit in the bracket): District code

833 (The fourth digit in the bracket): Tree species code (Wang, 2014). 


\subsection{Statistical Process}

After finishing remote sensing data processing, 4,160 observed values were generated from LiDAR data. To find the correlation between LiDAR and ground data, linear regression methods were used.

In the R Studio Version 1.0.153 software package; forward, backward, and stepwise selections were applied to derive the best fitting model to predict DBH from other variables using the step () function in base R (RStudio Team, 2016). While forward selection picks one predictor variable and adds another one at a time until it reaches the best equation, backward selection goes through the opposite direction. On the other hand, stepwise selection does the adding and subtracting together until it reaches the best model. These steps were applied for both 2011 and 2017 LiDAR data and 21 models were created.

In the end of model selection, based on their $\mathrm{R}^{2}$ values; Height, Crown Height, and Minimum Crown Diameter were selected as best correlated DBH predictors for the 2017 remote sensing data. However, for the 2011 data, Height, Crown Height, and Crown Radius were selected for best DBH predictions.

After testing the generated models, each model was applied to the other dataset. In other words, the model of 2017 was applied to 2011 dataset, and 2011's model was used for predicting DBH for 2017 dataset. The formulas for fit and validated statistics in the results section are below where ei is the prediction error. 


$$
\begin{gathered}
\text { PRMSE }=\frac{\sqrt{\sum_{i}^{n}\left(e i^{2}\right)}}{\sqrt{n-1}} \\
\text { BIAS }=\frac{\sum e i}{n} \\
M A D=\frac{\sum|e i|}{n}
\end{gathered}
$$

\section{Results}

A total of 52 measurement were made of the following tree species: 1 aspen, 2 Eastern hemlock, 9 red oak, 11 red pine, 20 sugar maple, 2 white birches, 5 white pine, and 2 yellow birch.

The LiDAR and ground (climbing) height measurements and the accuracy of LiDAR are shown in Appendix A. The results for derived equations are presented in Appendix B. Moreover, estimated volume and biomass for ground measured DBH and predicted volume and biomass by using estimated DBH from LiDAR variables for both 2011 and 2017 data are placed in Appendix C. Also, volume and biomass growth for 6 years are shown in Appendix C. In addition, the following statistics are shown in the tables below. Predicted Root Mean Square Error (PRMSE), Mean Error (BIAS), Mean Absolute Differences (MAD), some regression diagnostics, and distribution graphics of prediction errors based on total tree height and DBH. 
Table 2. Fit statistics for 2017 data

\begin{tabular}{|llll|}
\hline \multicolumn{4}{|c|}{ Testing 2017's equation on 2017 data } \\
\hline & RMSE & BIAS & MAD \\
General & 10.31 & 0.00 & 8.25 \\
Hardwoods & 10.63 & 0.23 & 8.32 \\
Softwoods & 9.99 & -0.43 & 8.12 \\
\hline
\end{tabular}
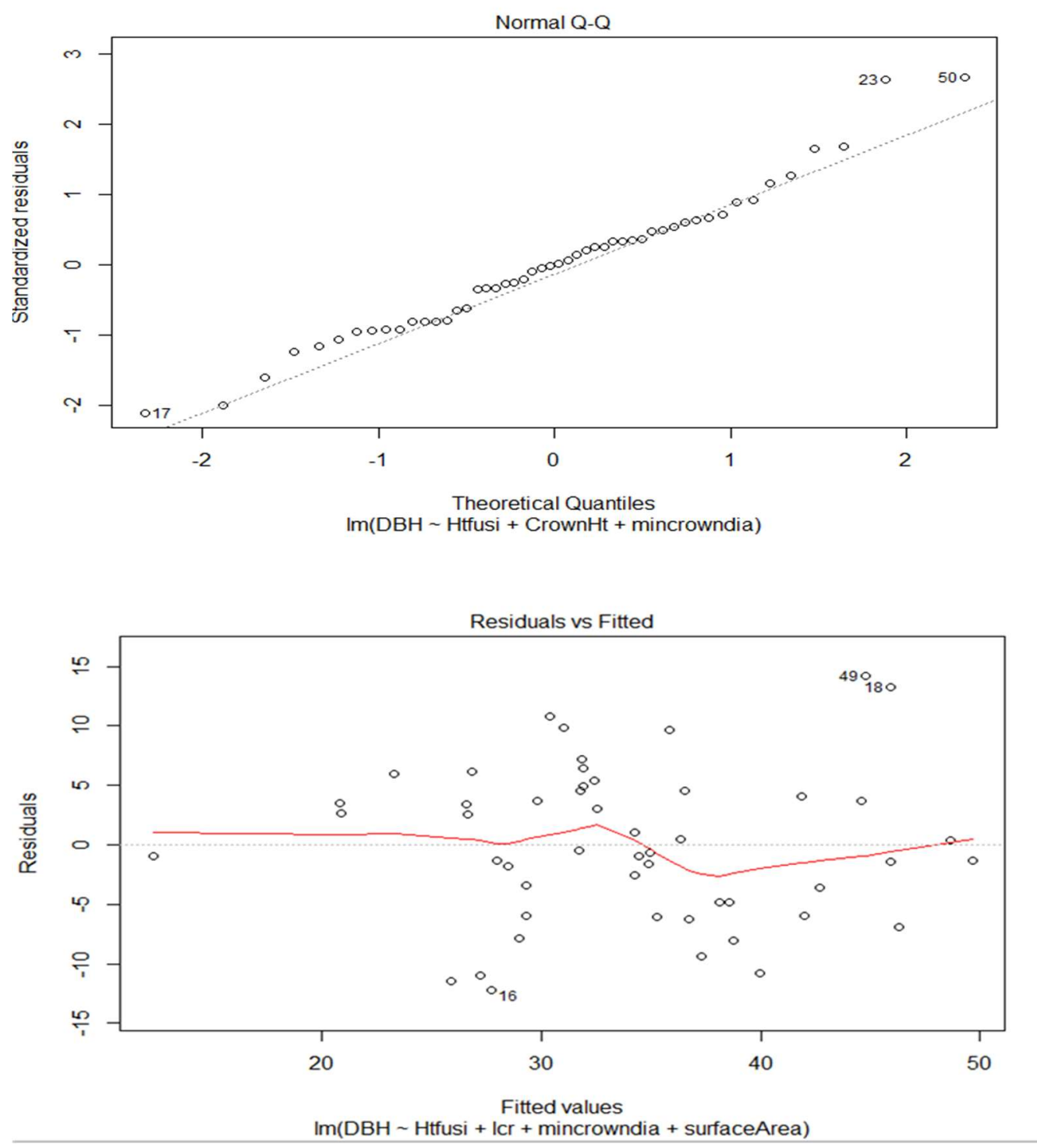

Figure 9. Regression diagnostics for the 2017 DBH estimation model tested on 2017 data. 


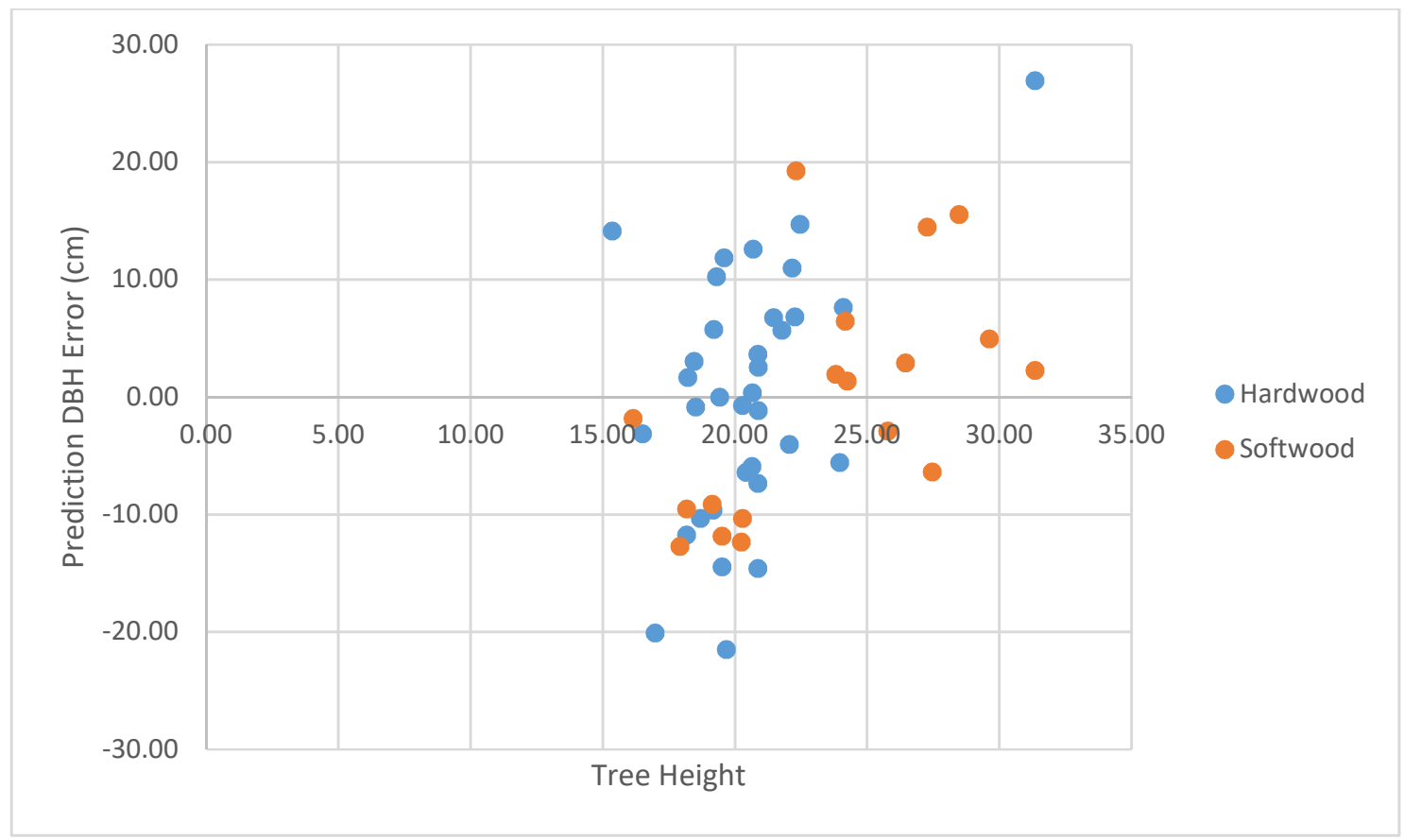

Figure 10. Distribution of DBH prediction error based on tree height for 2017 equation tested on 2017.

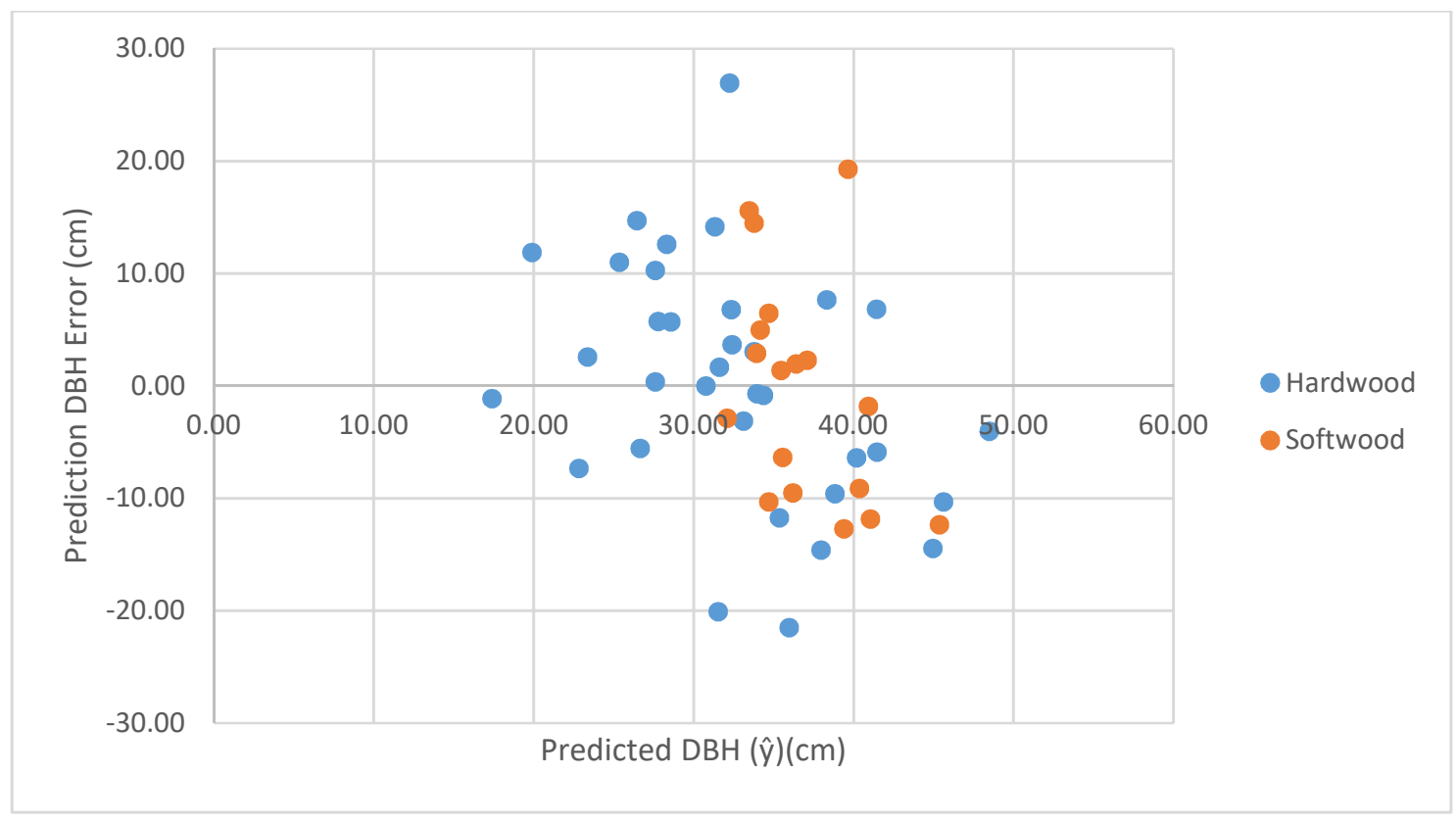

Figure 11. Distribution of DBH prediction error based on predicted DBH for 2017 equation tested on 2017. 
Table 3. Validation statistics for 2011 data

\begin{tabular}{|llll|}
\hline \multicolumn{4}{|c|}{ Testing 2017's equation on 2011 data } \\
\hline & PRMSE & BIAS & MAD \\
General & 7.58 & -0.25 & 6.32 \\
Hardwoods & 8.07 & -0.27 & 6.71 \\
Softwoods & 6.78 & -0.20 & 5.59 \\
\hline
\end{tabular}

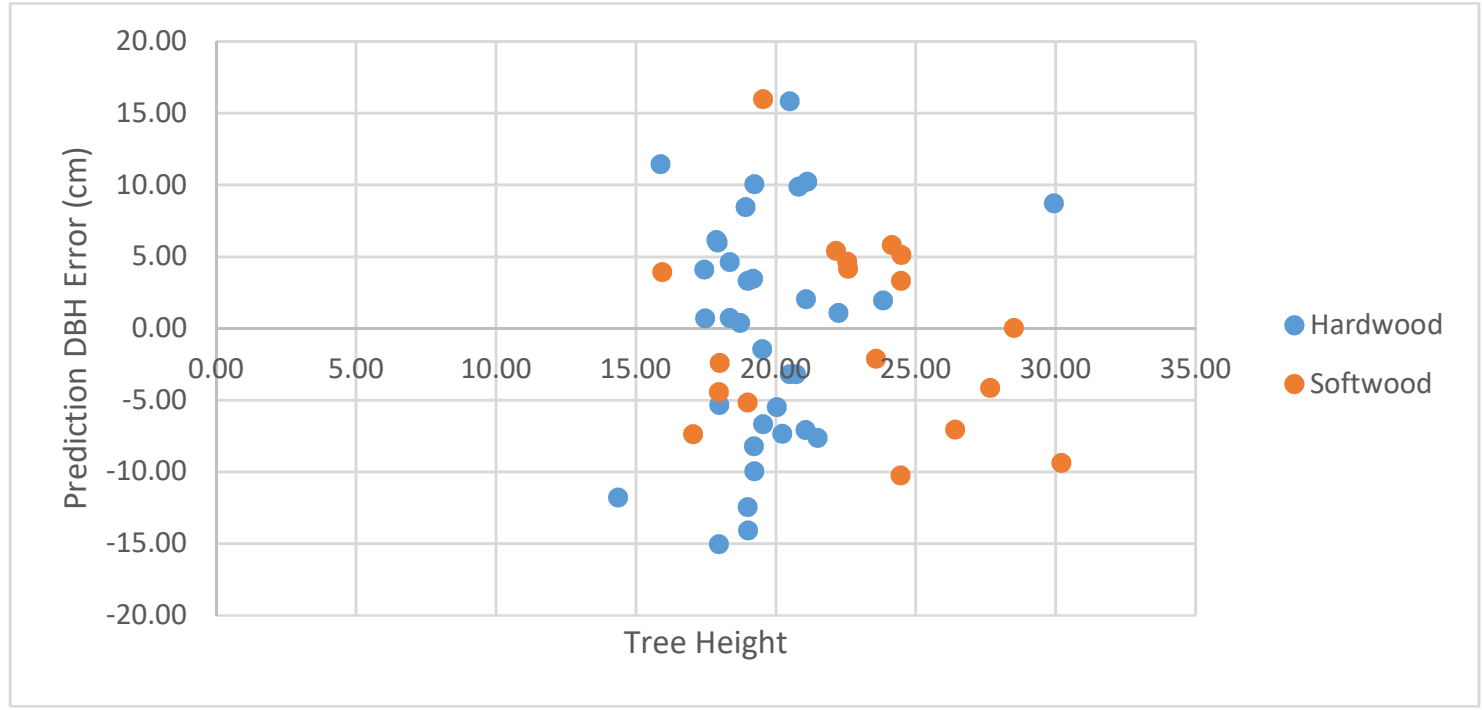

Figure 12. Distribution of DBH prediction error based on tree height for 2017 equation tested on 2011. 


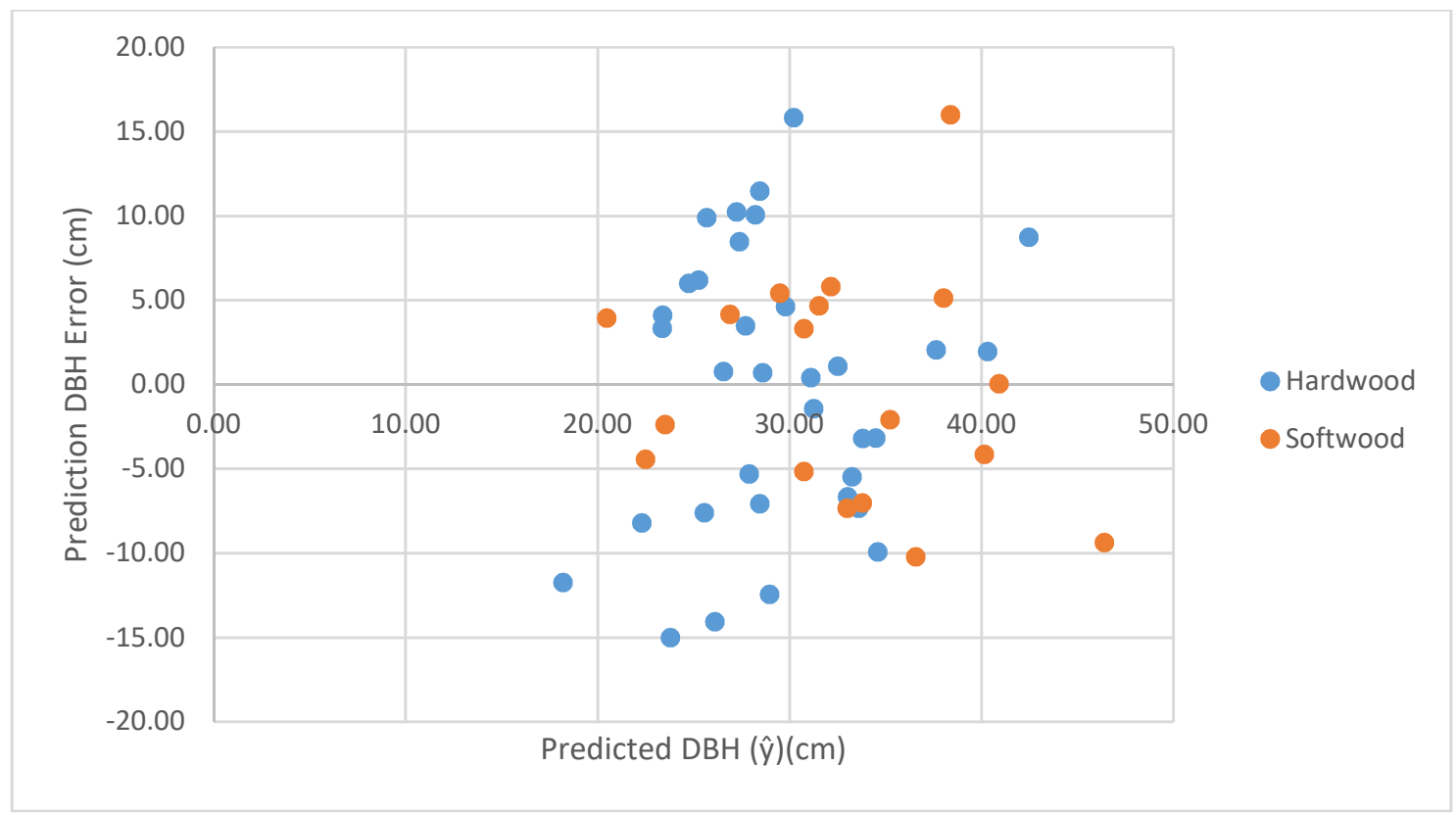

Figure 13. Distribution of DBH prediction error based on predicted DBH for 2017 equation tested on 2011.

Table 4. Fit statistics for 2011 data.

\begin{tabular}{|llll|}
\hline \multicolumn{4}{|c|}{ Testing 2011's equation on 2011 data } \\
\hline & RMSE & BIAS & MAD \\
General & 11.15 & 0.00 & 9.14 \\
Hardwoods & 11.15 & -0.89 & 8.88 \\
Softwoods & 11.46 & 1.67 & 9.62 \\
\hline
\end{tabular}



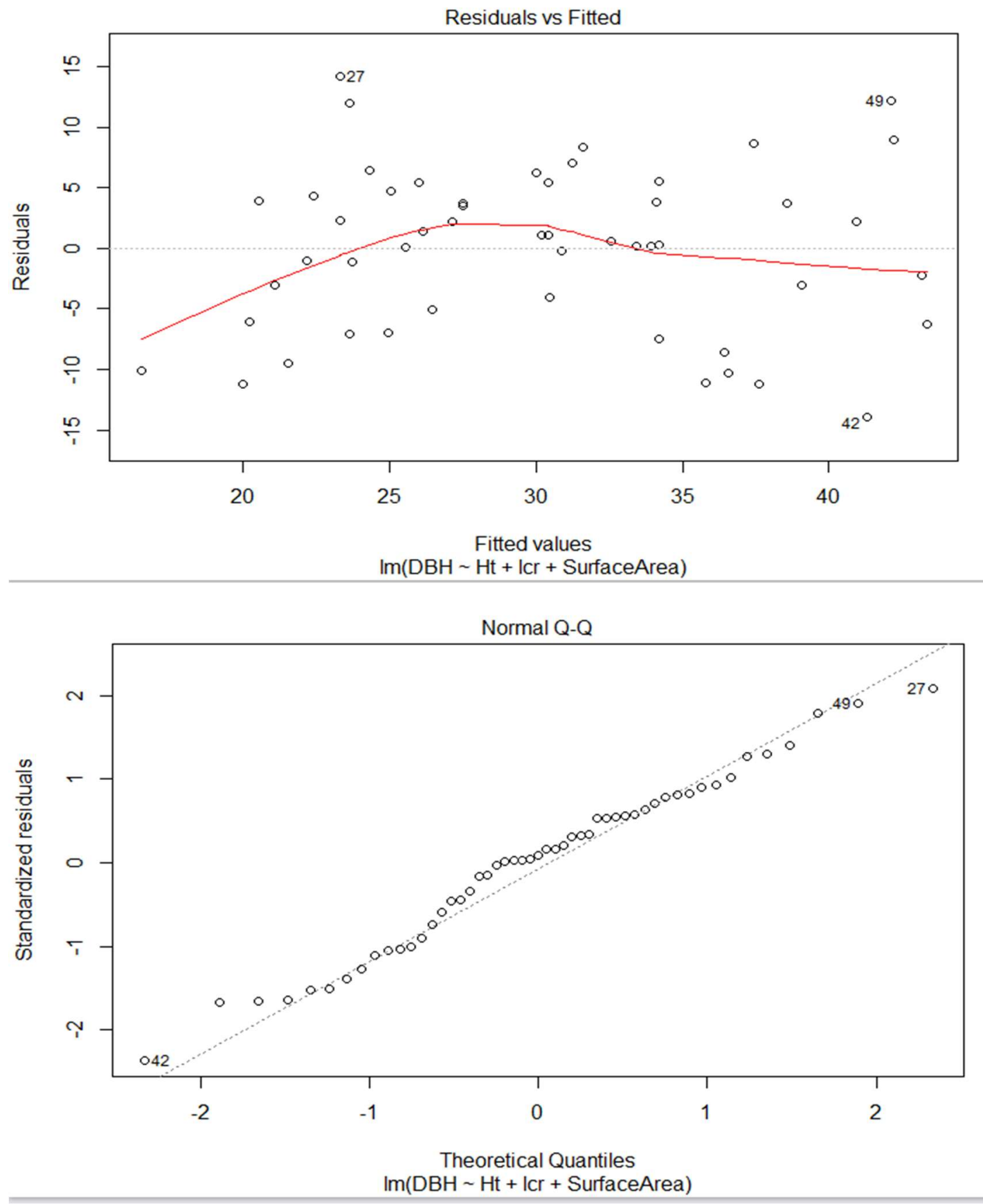

Figure 14. Regression diagnostics for the 2011 DBH estimation model tested on 2011 data. 


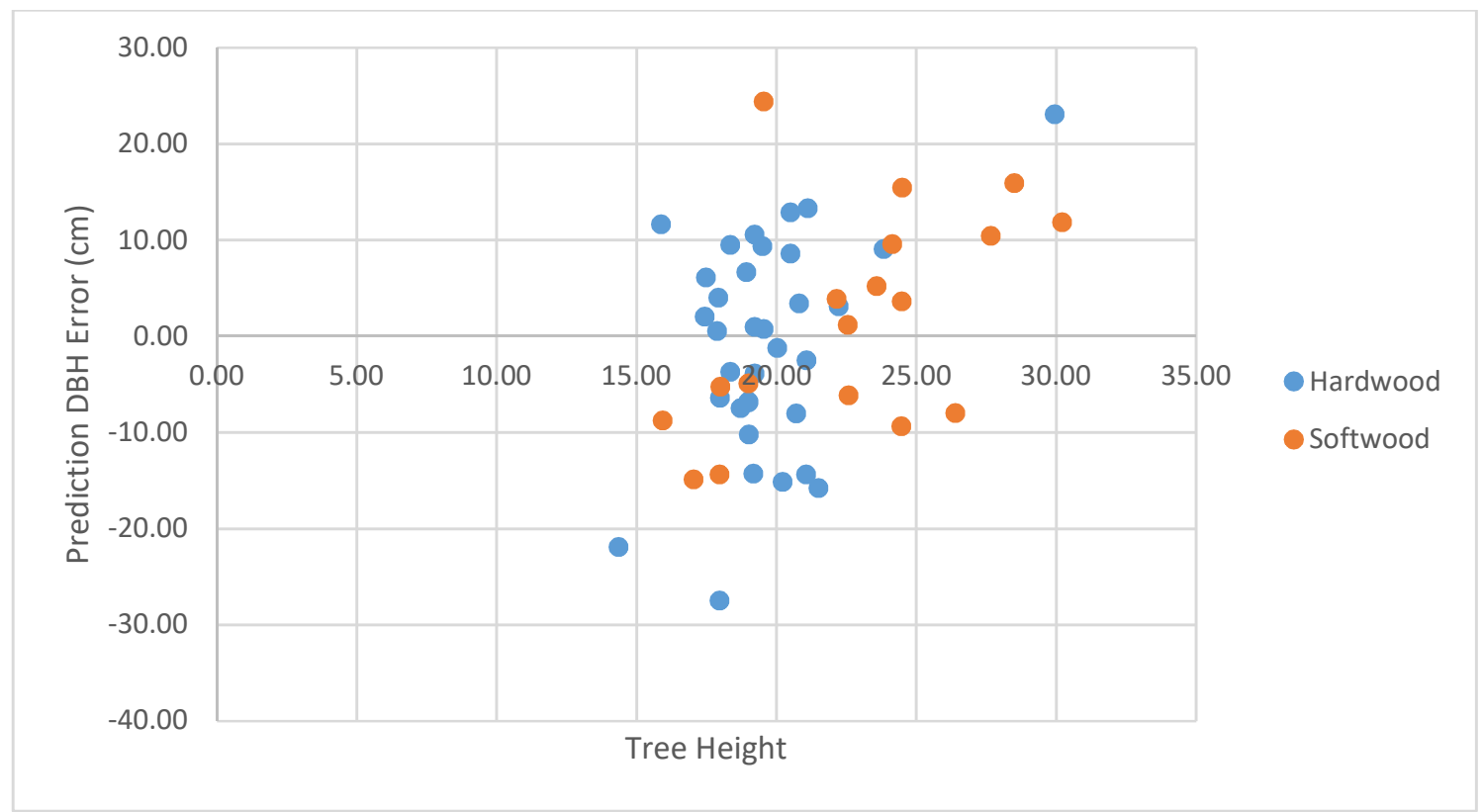

Figure 15. Distribution of DBH prediction error based on tree height for 2011 equation tested on 2011.

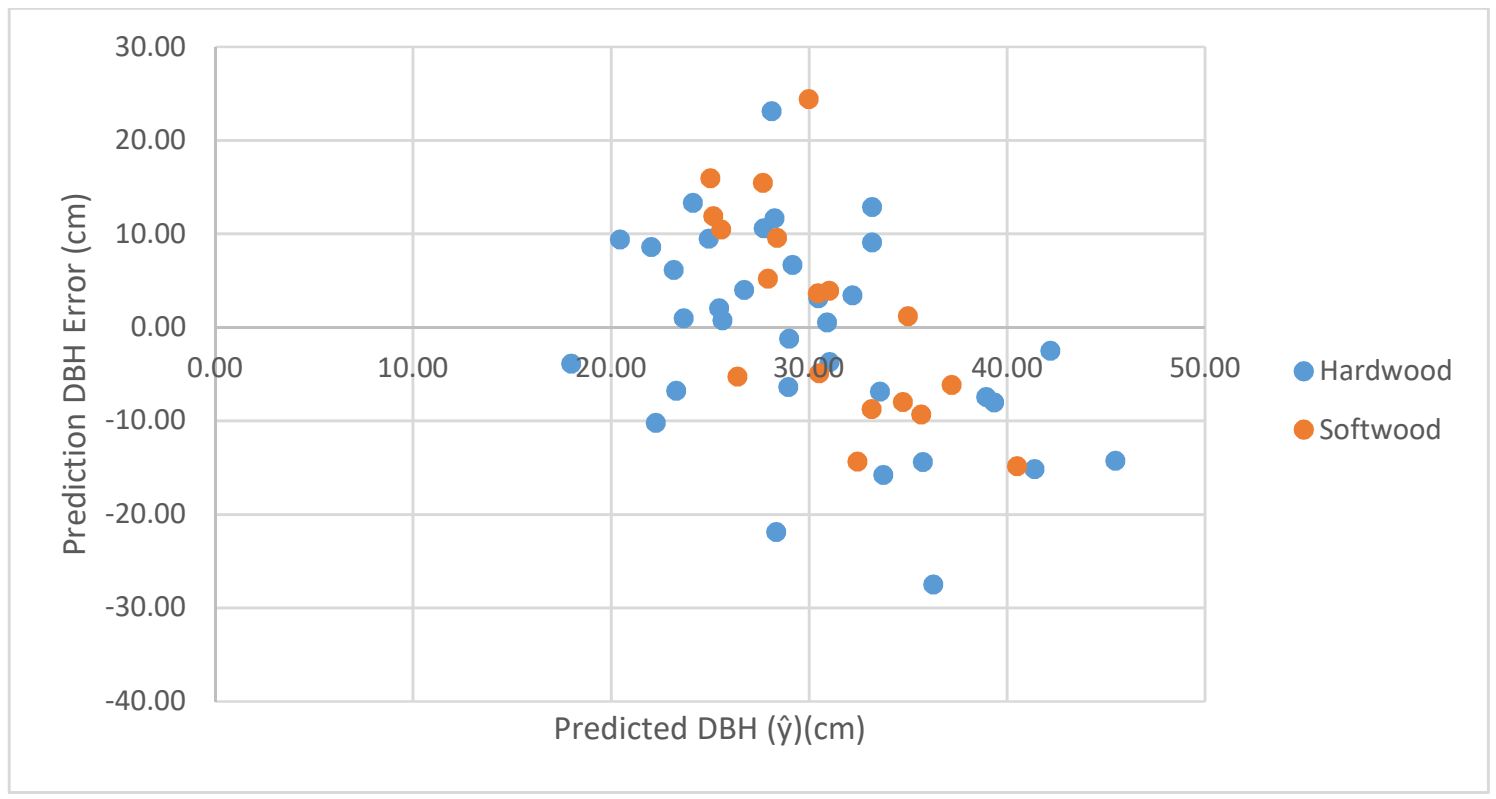

Figure 16. Distribution of DBH prediction error based on predicted DBH for 2011 equation tested on 2011. 
Table 5. Validation statistics for 2017 data

\begin{tabular}{|llll|}
\hline \multicolumn{4}{|c|}{ Testing 2011's equation on 2017 data } \\
\hline & PRMSE & BIAS & MAD \\
General & 7.85 & 0.25 & 5.94 \\
Hardwoods & 7.34 & -1.10 & 5.85 \\
Softwoods & 8.97 & 2.80 & 6.10 \\
\hline
\end{tabular}

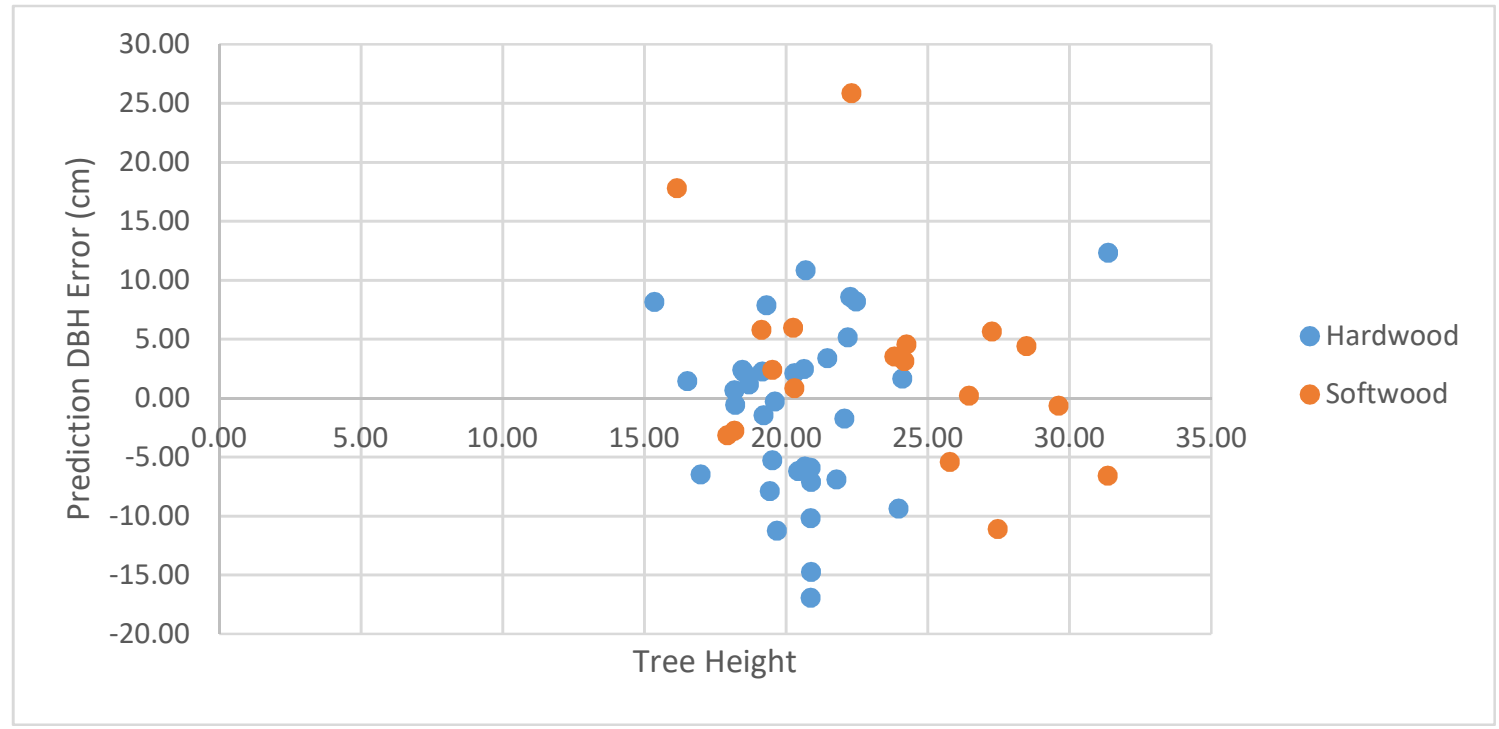

Figure 17. Distribution of DBH prediction error based on tree height for 2011 equation tested on 2017. 


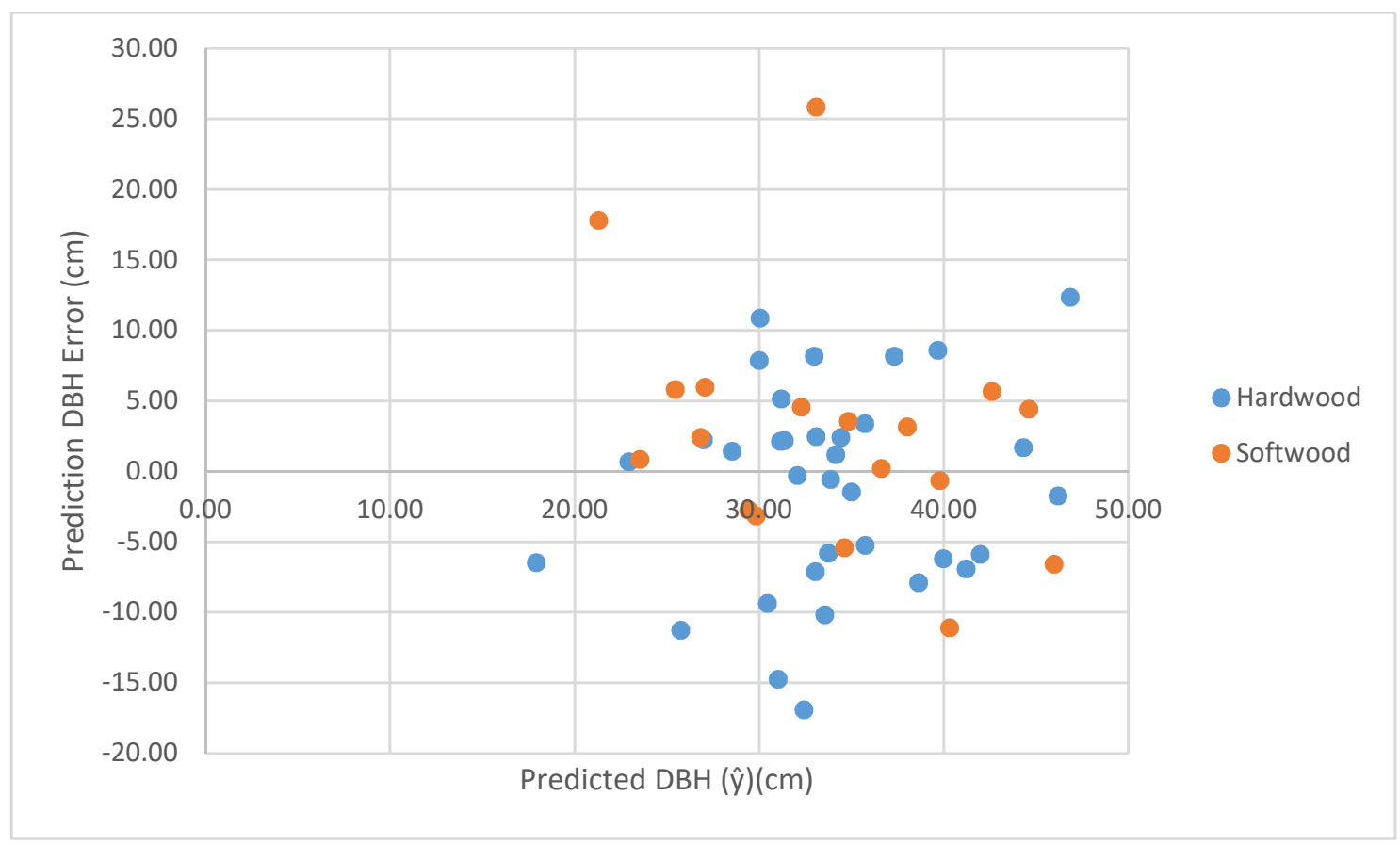

Figure 18. Distribution of DBH prediction error based on predicted DBH for 2011 equation tested on 2017.

Residuals vs Fitted graphics illustrates that residual values' line (red) is following a trend around zero line, which means the mean estimation residual value is approximately zero. Moreover, based on Normal Q-Q plots, predicted DBH values do not have statistically significant differences than ground measured DBHs. However, these formulas could be stronger with some arrangements, such as taking out some outliers from the dataset.

There is a broken canopy white pine in ground data (Tree ID is 23) and it has been realized after LiDAR measurements of 2011 that the tree was not broken in 2011. Therefore, while the DBH estimation equation for 2011 gets less error, the same equation will cost some increasing of the error on 2017 data. That would not be a problem if the 
dataset were bigger. Because there are only 52 single trees, the broken canopy tree should be taken out of the equation. The result tables are below after this step state that higher accuracy DBH estimations are possible without the outlier tree based on adjusted $\mathrm{R}^{2}$ values' comparisons:

Table $6 . \mathrm{R}^{2}$ and $\mathrm{p}$-value of equations created before taking out the broken tree

\begin{tabular}{|ccc|}
\hline Equation/tested dataset & Adjusted $\mathbf{R}^{2}$ & p-value \\
\hline $2017 / 2017$ & 0.3753 & $1.70 \mathrm{E}-05$ \\
$2017 / 2011$ & 0.3253 & \\
$2011 / 2011$ & 0.3281 & $5.89 \mathrm{E}-05$ \\
$2011 / 2017$ & 0.3589 & \\
\hline
\end{tabular}

Table 7. $\mathrm{R}^{2}$ and $\mathrm{p}$-value of equations created after taking out the broken tree

\begin{tabular}{|ccc|}
\hline Equation/tested dataset & Adjusted $\mathbf{R}^{\mathbf{2}}$ & p-value \\
\hline $2017 / 2017$ & 0.5491 & $2.348 \mathrm{e}-08$ \\
$2017 / 2011$ & 0.4231 & \\
$2011 / 2011$ & 0.4346 & $1.374 \mathrm{e}-06$ \\
$2011 / 2017$ & 0.5387 & \\
\hline
\end{tabular}

Table 8. Fit statistics for 2017 data after outlier tree was taken out of the dataset.

\begin{tabular}{|llll|}
\hline \multicolumn{3}{|l}{ Testing 2017's equation on 2017 data } \\
\hline & RMSE & BIAS & MAD \\
General & 6.41 & 0.00 & 5.17 \\
Hardwoods & 6.63 & -0.57 & 5.36 \\
Softwoods & 6.15 & 1.13 & 4.78 \\
\hline
\end{tabular}


Table 9. Validation statistics for 2011 data after outlier tree was taken out of the dataset.

\begin{tabular}{|llll|}
\hline \multicolumn{3}{|l|}{ Testing 2017's equation on 2011 data } & \\
\hline & PRMSE & BIAS & MAD \\
General & 6.91 & -0.14 & 5.54 \\
Hardwoods & 7.58 & -0.38 & 6.21 \\
Softwoods & 5.55 & 0.34 & 4.22 \\
\hline
\end{tabular}

Table 10. Fit statistics for 2011 data after outlier tree was taken out of the dataset.

\begin{tabular}{|lcll|}
\hline \multicolumn{3}{|l|}{ Testing 2011's equation on 2011 data } & \\
\hline & RMSE & BIAS & MAD \\
General & 6.79 & 0.00 & 5.48 \\
Hardwoods & 7.38 & -0.11 & 6.14 \\
Softwoods & 5.61 & 0.21 & 4.16 \\
\hline
\end{tabular}

Table 11. Validation statistics for 2017 data after outlier tree was taken out of the dataset.

\begin{tabular}{|llll|}
\hline \multicolumn{4}{|c|}{ Testing 2011's equation on 2017 data } \\
\hline PRMSE & BIAS & MAD \\
General & 6.56 & 0.00 & 5.23 \\
Hardwoods & 6.79 & -0.17 & 5.28 \\
Softwoods & 6.26 & 0.34 & 5.11 \\
\hline
\end{tabular}

By comparing adjusted $\mathrm{R}^{2}$ and BIAS values of pre and post outlier deletion, the accuracy and reliability of the predictions were increased significantly.

The coefficient estimates with significant predictors using stepwise method for 2017 fit model is presented below. It illustrates significant variables' accuracy and significance level on the estimation model based on their values on the table. 
Table 12. Coefficients for 2017 fit model

\begin{tabular}{|lcccc|}
\hline & Estimate & Std. Error & t value & $\operatorname{Pr}(>|\mathbf{t}|)$ \\
\hline (Intercept) & -23.6857 & 8.5462 & -2.771 & 0.00803 \\
Ht & 1.4778 & 0.2655 & 5.567 & $1.28 \mathrm{E}-06$ \\
lcr & 18.1222 & 8.0917 & 2.24 & 0.02999 \\
mincrowndia & 1.515 & 1.0483 & 1.445 & 0.15517 \\
crown & 0.1538 & 0.0644 & 2.388 & 0.0211 \\
\hline
\end{tabular}

Where;

Estimate: Values that come from fitted 2017 model for significant variables,

Std. Error: Standard error (A measure of the statistical accuracy of an estimate)

$t$ value: A ratio of the departure of the predicted value of a parameter from its hypothesized value to its standard error.

$\operatorname{Pr}(>|t|)$ : Level of significance that decide whether reject or fail to reject to the null hypothesis.

Ht: Total tree height derived from LiDAR in meter,

mincrowndia: Minimum tree crown diameter in meter,

lcr: Live crown ratio in meter,

crown: Tree crown footprints in meter square $\left(\mathrm{m}^{2}\right)$.

Also, for the same equation, adjusted $\mathrm{R}^{2}$ was 0.55 and $\mathrm{p}$-value was less than 0.01 . 
After testing 2017 model on 2011 dataset, the coefficient estimates with significant predictors are as shown below.

Table 13 . Coefficients for 2011 validation model

\begin{tabular}{|lcccc|}
\hline & Estimate & Std. Error & t value & $\operatorname{Pr}(>|\mathbf{t}|)$ \\
\hline Intercept) & -25.0821 & 12.81007 & -1.958 & 0.056311 \\
Ht & 1.84086 & 0.38057 & 4.837 & $1.52 \mathrm{E}-05$ \\
lcr & 15.57174 & 15.52917 & 1.003 & 0.321231 \\
mincrowndia & 0.36857 & 0.87624 & 0.421 & 0.675983 \\
crown & 0.27122 & 0.07075 & 3.834 & 0.000382 \\
\hline
\end{tabular}

Adjusted $\mathrm{R}^{2}$ was 0.48 and p-value was less than 0.01 as a result of this model test.

Then, the fit model for 2011 data were created and the coefficient estimates with significant predictors are as below.

Table 14. Coefficients for 2011 fit model

\begin{tabular}{|lcccc|}
\hline & Estimate & Std. Error & t value & $\operatorname{Pr}(>|\mathbf{t}|)$ \\
\hline (Intercept) & -24.2607 & 12.54898 & -1.933 & 0.059238 \\
Ht & 1.83906 & 0.3772 & 4.876 & $1.28 \mathrm{E}-05$ \\
Icr & 18.7325 & 13.47055 & 1.391 & 0.170889 \\
crown & 0.27534 & 0.06945 & 3.965 & 0.000249 \\
\hline
\end{tabular}

Adjusted $\mathrm{R}^{2}$ value was 0.49 and $\mathrm{p}$-value was less than 0.01 for 2011 's fitted model.

Afterward, 2011 fitted model was tested on 2017 dataset and the results below were obtained. 
Table 15. Coefficients for 2017 validation model

\begin{tabular}{|lcccc|}
\hline & Estimate & Std. Error & $\mathbf{t}$ value & $\operatorname{Pr}(>|\mathbf{t}|)$ \\
\hline (Intercept) & -17.30888 & 7.4033 & -2.338 & 0.0237 \\
Ht & 1.47368 & 0.26849 & 5.489 & $1.58 \mathrm{E}-06$ \\
lcr & 22.31815 & 7.63992 & 2.921 & 0.00534 \\
crown & 0.19161 & 0.05953 & 3.219 & 0.00234 \\
\hline
\end{tabular}

Also, adjusted $\mathrm{R}^{2}$ was 0.54 and p-value was less than 0.01 for that test.

Additionally, subject trees were separated species, hardwood and softwood, and linear regression analysis were run to see the accuracy of broad leaves and coniferous trees.

Table 16. Coefficients for hardwood species in 2017 fit model

\begin{tabular}{|lcccr|}
\hline & Estimate & Std. Error & t value & $\operatorname{Pr}(>|\mathbf{t}|)$ \\
\hline (Intercept) & -29.74802 & 10.80757 & -2.753 & 0.009939 \\
Ht & 1.97783 & 0.46018 & 4.298 & $1.67 \mathrm{E}-04$ \\
lcr & 27.26228 & 9.95573 & 2.738 & 0.010286 \\
crown & 0.17743 & 0.07474 & 2.374 & 0.024196 \\
\hline
\end{tabular}

Adjusted $\mathrm{R}^{2}$ was 0.53 and $\mathrm{p}$-value was less than 0.01 for this model. After that, this model was tested on 2011 hardwood tree species data and results were as below.

Table 17. Coefficients for hardwood species in 2011 validation model

\begin{tabular}{|lcccc|}
\hline & Estimate & Std. Error & t value & $\operatorname{Pr}(>|\mathbf{t}|)$ \\
\hline (Intercept) & -39.8725 & 17.09095 & -2.333 & 0.026546 \\
Ht & 2.64611 & 0.59576 & 4.442 & $1.12 \mathrm{E}-04$ \\
Icr & 20.93712 & 16.5042 & 1.269 & 0.214342 \\
crown & 0.2253 & 0.08463 & 2.662 & 0.012354 \\
\hline
\end{tabular}

Adjusted $\mathrm{R}^{2}$ was 0.46 and $\mathrm{p}$-value was less than 0.01 for the validation model. 
Another fit model was created for 2011 hardwood tree data and it was validated on 2017 data, and the results were as illustrated below.

Table 18. Coefficients for hardwood species in 2011 fit model

\begin{tabular}{|lcccc|}
\hline & Estimate & Std. Error & t value & $\operatorname{Pr}(>|\mathbf{t}|)$ \\
\hline (Intercept) & -22.81907 & 10.65746 & -2.141 & 0.040234 \\
Ht & 2.25894 & 0.51666 & 4.372 & $1.29 \mathrm{E}-04$ \\
crown & 0.27 & 0.07769 & 3.475 & 0.001531 \\
\hline
\end{tabular}

Adjusted $\mathrm{R}^{2}$ value was 0.45 where $\mathrm{p}$-value was less than 0.01 for the fitting model.

Table 19. Coefficients for hardwood species in 2017 validation model

\begin{tabular}{|lcccc|}
\hline & Estimate & Std. Error & t value & $\operatorname{Pr}(>|\mathbf{t}|)$ \\
\hline (Intercept) & -20.86604 & 11.33857 & -1.84 & 0.07532 \\
Ht & 2.07471 & 0.50463 & 4.111 & $2.68 \mathrm{E}-04$ \\
crown & 0.28338 & 0.07033 & 4.029 & 0.000337 \\
\hline
\end{tabular}

Adjusted $\mathrm{R}^{2}$ was 0.43 and p-value was less than 0.01 for the validation model.

Same process were applied to the softwood species and results were as follows.

Table 20. Coefficients for softwood species in 2017 fit model

\begin{tabular}{|lcccc|}
\hline & Estimate & Std. Error & t value & $\operatorname{Pr}(>|\mathbf{t}|)$ \\
\hline (Intercept) & 147.38539 & 54.43672 & 2.707 & 0.019 \\
Ht & -6.26736 & 2.6312 & -2.382 & $3.46 \mathrm{E}-02$ \\
CrownHt & 14.25484 & 5.39333 & 2.643 & $2.15 \mathrm{E}-02$ \\
lcr & -279.61097 & 107.6663 & -2.597 & $2.34 \mathrm{E}-02$ \\
crown & 0.29253 & 0.07932 & 3.688 & 0.0031 \\
\hline
\end{tabular}

Adjusted $\mathrm{R}^{2}$ was 0.75 and $\mathrm{p}$-value was less than 0.01 for the fitting model. 
Table 21. Coefficients for softwood species in 2011 validation model

\begin{tabular}{|lcccc|}
\hline & Estimate & Std. Error & t value & $\operatorname{Pr}(>|\mathbf{t}|)$ \\
\hline (Intercept) & -6.693 & 48.3697 & -0.138 & 0.892242 \\
Ht & 0.9089 & 2.1791 & 0.417 & $6.84 \mathrm{E}-01$ \\
CrownHt & 0.6333 & 5.1413 & 0.123 & $9.04 \mathrm{E}-01$ \\
lcr & 2.533 & 107.4691 & 0.024 & $9.82 \mathrm{E}-01$ \\
crown & 0.4617 & 0.1006 & 4.588 & 0.000624 \\
\hline
\end{tabular}

Adjusted $\mathrm{R}^{2}$ was 0.71 and p-value was less than 0.01 for the validation model.

Table 22. Coefficients for softwood species in 2011 fit model

\begin{tabular}{|lcccc|}
\hline & Estimate & Std. Error & t value & $\operatorname{Pr}(>|\mathbf{t}|)$ \\
\hline Intercept) & -12.7948 & 15.2159 & -0.841 & 0.41832 \\
Ht & 1.183 & 0.3899 & 3.034 & $1.14 \mathrm{E}-02$ \\
CrownRadius & 2.5744 & 2.1515 & 1.197 & $2.57 \mathrm{E}-01$ \\
MinCrownDia & -2.6251 & 1.493 & -1.758 & $1.06 \mathrm{E}-01$ \\
lcr & 31.1706 & 20.4889 & 1.521 & $1.56 \mathrm{E}-01$ \\
crown & 0.4467 & 0.1076 & 4.15 & 0.00162 \\
\hline
\end{tabular}

Adjusted $\mathrm{R}^{2}$ was 0.76 and p-value was less than 0.01 for the fitting model.

Table 23. Coefficients for softwood species in 2017 validation model

\begin{tabular}{|lcccr|}
\hline & Estimate & Std. Error & t value & $\operatorname{Pr}(>|\mathbf{t}|)$ \\
\hline Intercept) & -35.29277 & 12.17466 & -2.899 & 0.007203 \\
Ht & 1.94031 & 0.47113 & 4.118 & $3.06 \mathrm{E}-04$ \\
CrownRadius & -0.13061 & 2.89381 & -0.045 & $9.64 \mathrm{E}-01$ \\
MinCrownDia & 1.65801 & 2.00102 & 0.829 & $4.14 \mathrm{E}-01$ \\
lcr & 21.04496 & 12.34186 & 1.705 & $9.92 \mathrm{E}-02$ \\
crown & 0.14527 & 0.08223 & 1.767 & 0.088203 \\
\hline
\end{tabular}

Adjusted $\mathrm{R}^{2}$ was 0.52 for the validation model where $\mathrm{p}$-value was less than 0.01 . 


\section{Discussion}

The main weakness of this research is identifying tree species using LiDAR in a mixed forest stand, as crown architecture is not a reliable predictor for tree species identification. Additional remote sensing techniques, such as hyperspectral imagery could be used simultaneous with a LiDAR dataset to identify tree species in mixed forest structure (Holmgren, et al., 2008; Naidoo, et al., 2012). Although species identification is not important for DBH estimations, it is vital to be able to predict stem volume and biomass. The existent biomass and volume prediction models require species as an input variable, as the tree growth rate differs between species. For example, even though two different species may have the same DBH, the height, crown width, and accordingly the volume and biomass values may differ. Therefore, identifying tree species is essential.

The results showed that the accuracy between LiDAR and ground height measurements is higher for coniferous trees than deciduous trees. It has not tested in this study; however, according to Kwak et al. (2007), the reason behind that is conic shapes of coniferous crown since observing the peak and the bottom of the tree is easier.

The ground measurements were taken in fall 2017 and spring 2018 even though LiDAR data were collected in summer 2017. Because the subject trees were already mature, or over-mature, this situation is not substantial for one growing season. Therefore, the discrepancy between LiDAR data collection and ground measurements should be of reduced concern. 
This study has some strengths for forest inventory calculations for wide study areas by using only LiDAR data collection. Without taking ground measurements, the ITD method can be applied to representative trees of each plots; tree parameters, which include DBH, volume, biomass etc., can be calculated and the results generalized to whole study area. This gives the opportunity of performing forest inventory with less work, time and money (Hummel et al., 2011). With additional LiDAR-derived variables such as Canopy Height Model (CHM), the model can be automated for larger forested areas (Fallowski et al., 2006). There are number of different previous studies to detect the height, crown diameter, and the location of individual trees using LiDAR-derived CHM (Fallowski et al., 2006). However, only two of them are discussed in this study. The first technique detects the local maxima (tree heights) inside the CHM using variable-sized windows (Popescu et al., 2003; Popescu and Wynne, 2004). The second method, on the other hand, exerts 2-dimensional wavelet analysis for measuring stand heights and diameter of tree crown directly from the CHM (Fallowski et al., 2006).

For determining the tree location, high accuracy GNSS was used in this study. The results of GNSS data post-processing in Trimble GPS Pathfinder Office shows that the precision error was 1.00 meter or less. It was important for matching trees on the ground to those identified in the LiDAR point clouds. Lower accuracy GNSS could result in measuring the wrong tree in LiDAR dataset.

While 18 pulses per $\mathrm{m}^{2}$ was the minimum pulse density of 2011 LiDAR dataset, the minimum in the 2017 LiDAR data collection was a minimum of 20 pulses per $\mathrm{m}^{2}$. 
Therefore, some deficiency of detecting small trees under dominant trees in plots may have been eliminated by more dense laser pulses in 2017.

The results of linear regression indicates that the broken canopy tree has negative effects on 2017 data even though it affects 2011 dataset positively. However, the effect on 2011 is less than 0.01 in $\mathrm{R}^{2}$ while the effect is crucially increase around 0.9 in $\mathrm{R}^{2}$ value. Hence, counting out the broken tree is a better option to gain higher confidence to the 2017 equation. Moreover, based on the results in Table 7, the best-fitted equation is 2017 since the $\mathrm{R}^{2}$ was 0.55 and p-value was less than 0.0001 for $2017 \mathrm{LiDAR}$ data, and $\mathrm{R}^{2}$ was 0.42 and p-value was less than 0.0001 for 2011 LiDAR dataset. $\mathrm{R}^{2}$ for 2011 equation tested on 2011 was 0.44 and p-value $<0.0001$. Since there is a slight difference between two $\mathrm{R}^{2}$ values for 2011 data (less than 0.01), 2017 equation can be accepted as better fitted than 2011 equation.

The broken tree was taken out since there were 8 different tree species and only 52 subject trees. Because of the limited dataset, only one anomaly caused significant estimation errors as it mentioned above. However, for a bigger dataset, a broken canopy may not be an issue and is highly likely in the nature. Nevertheless, the model created in this study ignores the broken tree canopies and that may result in over biomass or volume estimations for wider study area and real world applications.

In addition, species-based linear regression illustrates that DBH estimations for softwood species were more accurate than hardwoods. The model performs well for northern Michigan coniferous trees, yet the reliability of the softwood linear models are 
questionable for the rest of the county. The reason for questioning the model reliability outside of the study area is that there were only 17 subject softwood trees and topographic features' inequalities. Nonetheless, the model might rerun after increasing the tree number for the next studies.

Even though DBH is not a variable that can be directly measured from LiDAR, previous studies have stated that there is a strong correlation with stem height (Green, 1981; Arabatzis and Burkhart, 1992) and crown width (Sprinz and Burkhart, 1987; Smith et al., 1992; Gill, Biging and Murphy, 2000). In addition, Popescu (2007) indicates in his study that height and crown width are significant tree variables on DBH predictions. As a matter of fact, after all the analysis, this study demonstrates that the best indicators of DBH are total tree height, tree live crown ratio, minimum tree crown diameter, and tree crown footprint for Ford Center and Forest in Upper Peninsula, Michigan.

\section{Conclusion}

The purpose of this study was generating inventory models for Ford Forest Center using available two different LiDAR datasets and ground measured data. Hence, a big amount of tree variables were measured with 2011 and 2017 LiDAR point clouds separately and each of them combined with ground data. Linear regression was used for statistical method based on ground data. Then, created equations were tested on the other dataset, meaning 2017's equation was tested on 2011 dataset and 2011's equation was testing on 2017 data. 
This study shows that LiDAR is a reliable remote sensing instrument to measure and predict individual tree variables such as height and crown dimensions in the dominant canopy, thus improves the estimation of volume and biomass with less work and less time. DBH estimations, on the other hand, might be explained more than this study by inserting some other LiDAR measured tree variables such as canopy point density for the future studies. 


\section{References}

Almeida, D. R., Nelson, B. W., Schietti, J., Gorgens, E. B., Resende, A. F., Stark, S. C., \& Valbuena, R. (2016). Contrasting fire damage and fire susceptibility between seasonally flooded forest and upland forest in the Central Amazon using portable profiling LiDAR. Remote Sensing of Environment, 184, 153-160. doi:10.1016/j.rse.2016.06.017

Andersen, H., McGaughey, R. J., \& Reutebuch, S. E. (2005). Estimating forest canopy fuel parameters using LIDAR data. Remote Sensing of Environment, 94(4), 441-449. doi:10.1016/j.rse.2004.10.013

Ahern, F.J., Janetos, A.C. \& Langham, E. (1998) Global observation of forest cover: one component of CEOS' integrated global observing strategy, pp. 1-5. 27 th International Symposium on Remote Sensing of Environment, Tromsø, Norway.

Arabatzis, A.A., Burkhart H.E. (1992). An evaluation of sampling methods and model forms for estimating height-diameter relationships in loblolly pine plantations. Forest Science, 38 (1) (1992), pp. 192-198

Avery, T. E., \& Burkhart, H. E. (2002). Forest measurements. Boston: McGraw-Hill.

Beguet, B., Chehata, N., Boukir, S., \& Guyon, D. (2014, July). Classification of forest structure using very high-resolution Pleiades image texture. In 2014 IEEE Geoscience and Remote Sensing Symposium (pp. 2324-2327). IEEE. 
Bragg, D. C. (2014). Accurately measuring the height of (real) forest trees. Journal of Forestry, 112(1), 51-54. Retrieved from https://search.proquest.com/docview/1509070881?accountid=28041

Breiman, L. (2001). Random forests. Machine learning, 45(1), 5-32.

Brosofske, K. D., Froese, R. E., Falkowski, M. J., \& Banskota, A. (2014). A review of methods for mapping and prediction of inventory attributes for operational forest management. Forest Science, 60(4), 733-756.

Brandtberg, T. (2007). Classifying individual tree species under leaf-off and leaf-on conditions using airborne lidar. ISPRS Journal of Photogrammetry and Remote Sensing, 61(5), 325-340.

Chave, J. (2005) Measuring tree height for tropical forest trees - A field manual. www.rainfor.org/upload/ManualsEnglish/TreeHeight_english[1].pdf.

Clark, D.A. \& Clark, D.B. (2001) Getting to the canopy: tree height growth in a Neotropical rain forest. Ecology, 82, 1460-1472.

Cohen, W.B., Harmon, M.E., Wallin, D.O. \& Fiorella, M. (1996) Two decades of carbon flux from forests of the Pacific Northwest. Bioscience, 46, 836-844.

Edson, C., and M.G. Wing. 2011. Airborne light detection and ranging (LiDAR) for individual tree stem location, height, and biomass measurements. Remote Sens. 3(11):2494- 2528. doi: 10.3390/rs3112494. 
Dupuy, S., Lainé, G., Tassin, J., \& Sarrailh, J. M. (2013). Characterization of the horizontal structure of the tropical forest canopy using object-based LiDAR and multispectral image analysis. International Journal of Applied Earth Observation and Geoinformation, 25, 76-86. doi:10.1016/j.jag.2013.04.001

Falkowski, M.J., Smith A.M.S., Hudak, A.T., Gessler, P.E., Vierling, L.A., Crookston, N.L. (2006). Automated estimation of individual conifer tree height and crown diameter via two-dimensional spatial wavelet analysis of lidar data. Can J Remote Sensing. 32(2):153-161.

Falkowski, M. J., Evans, J. S., Martinuzzi, S., Gessler, P. E., \& Hudak, A. T. (2009). Characterizing forest succession with lidar data: An evaluation for the Inland Northwest, USA. Remote Sensing of Environment, 113(5), 946-956. doi:10.1016/j.rse.2009.01.003

Falkowski, M. J., Hudak, A. T., Crookston, N. L., Gessler, P. E., Uebler, E. H., \& Smith, A. M. S. (2010). Landscape-scale parameterization of a tree-level forest growth model: ak-nearest neighbor imputation approach incorporating LiDAR data. Canadian Journal of Forest Research, 40(2), 184-199. doi:10.1139/x09-183

Fowler, G.W. and Damschroder, L.J. (1988). A Red Pine Bark Factor Equation for Michigan. Northern Journal of Applied Forestry, Vol. 5, No. 1 
Fowler, G.W., Hussain N.G., Cohen, D.J., Khatry-Chhetri, D. (1997). Bark Factor Equations for Oak in Michigan. Forestry Information Leaflet, Forest Management Division, Michigan Department of Natural Resources, 2-97.

Fowler, G.W., Hussain N.G., Cohen, D.J., Khatry-Chhetri, D. (1999). Bark Factor Equations for Northern Hardwoods in Michigan. Forestry Information Leaflet, Forest Management Division, Michigan Department of Natural Resources, 1-99.

Gebuhr, Timothy J., "Applications of LiDAR remote sensing of forest structure in the Upper Great Lakes region, USA", Master's Thesis, Michigan Technological University, 2013.

http://digitalcommons.mtu.edu/etd-restricted/156

Gevorkiantz, S.R., and L. P. Olsen. 1955. Composite Volume Tables for Timber and Their Application in the Lake States. USDA Forest Service Technical Bulletin No. 1104

Gill, S.J., Biging, G.S., Murphy E.C. (2000). Modeling conifer tree crown radius and estimating canopy cover. Forest Ecology and Management, 126 (2000), pp. $405-416$

Graves, H.S. 1906. Forest mensuration. John Wiley \& Sons, New York. 458 p. 
Green EJ. (1981). Models of stand basal area distributions, individual tree basal area growth, and height-diameter relationships for loblolly pine. Ph.D. dissertation. Blacksburg, VA: Virginia Polytechnic Institute and State University.

Gregersen, E., (2018). Lidar. Encyclopædia Britannica, inc. Available from https://www.britannica.com/technology/lidar

Guo, L., Chehata, N., Mallet, C., \& Boukir, S. (2011). Relevance of airborne lidar and multispectral image data for urban scene classification using Random Forests. ISPRS Journal of Photogrammetry and Remote Sensing, 66(1), 56-66.

Hopkinson, C., Chasmer, L., Barr, A. G., Kljun, N., Black, T. A., \& McCaughey, J. H. (2016). Monitoring boreal forest biomass and carbon storage change by integrating airborne laser scanning, biometry and eddy covariance data. Remote Sensing of Environment, 181, 82-95. doi:10.1016/j.rse.2016.04.010

Hu, T., Su, Y., Xue, B., Liu, J., Zhao, X., Fang, J., \& Guo, Q. (2016). Mapping Global Forest Aboveground Biomass with Spaceborne LiDAR, Optical Imagery, and Forest Inventory Data. Remote Sensing, 8(7), 565. doi:10.3390/rs8070565

Hudak, A. T., Crookston, N. L., Evans, J. S., Hall, D. E., \& Falkowski, M. J. (2008). Nearest neighbor imputation of species-level, plot-scale forest structure attributes from LiDAR data. Remote Sensing of Environment, 112(5), 2232-2245. doi:10.1016/j.rse.2007.10.009 
Hudak, A. T., Evans, J. S., \& Stuart Smith, A. M. (2009). LiDAR utility for natural resource managers. Remote Sensing, 1(4), 934-951.

Hudak, A. T., Bright, B. C., Pokswinski, S. M., Loudermilk, E. L., O’Brien, J. J., Hornsby, B. S., Silva, C. A. (2016). Mapping Forest Structure and Composition from Low-Density LiDAR for Informed Forest, Fuel, and Fire Management at Eglin Air Force Base, Florida, USA. Canadian Journal of Remote Sensing, 42(5), 411-427. doi:10.1080/07038992.2016.1217482

Hummel, S., Hudak, A. T., Uebler, E. H., Falkowski, M. J., \& Megown, K. A. (2011). A comparison of accuracy and cost of LiDAR versus stand exam data for landscape management on the Malheur National Forest. Journal of Forestry, 109(5), 267273.

Hyde, P., Dubayah, R., Peterson, B., Blair, J., Hofton, M., Hunsaker, C., Walker, W. (2005). Mapping forest structure for wildlife habitat analysis using waveform lidar: Validation of montane ecosystems. Remote Sensing of Environment, 96(3-4), 427-437. doi:10.1016/j.rse.2005.03.005

Jeronimo, S. M. A., Kane, V. R., Churchill, D. J., McGaughey, R. J., Franklin, J. F.; Applying LiDAR Individual Tree Detection to Management of Structurally Diverse Forest Landscapes, Journal of Forestry, Volume 116, Issue 4, 29 June 2018, Pages 336-346, https://doi.org/10.1093/jofore/fvy023 
Korning, J. \& Thomsen, K. (1994) A new method for measuring tree height in tropical rainforest. Journal of Vegetation Science, 5, 139-140.

Kozak, A., Yang, R.C. (1981). Equations for Estimating Bark Volume and Thickness of Commercial Trees in British Columbia. The Forestry Chronicle.

Kwak, DA., Lee, WK., Lee, JH. et al. (2017). Detection of individual trees and estimation of tree height using LiDAR data. Journal of Forest Research, 6, 425-434. https://doi.org/10.1007/s10310-007-0041-9

Lillesand, T., Kiefer, R. W., \& Chipman, J. (2014). Remote sensing and image interpretation. John Wiley \& Sons.

Larjavaara M. \& Muller-Landau H. C. (2013). Measuring tree height: a quantitative comparison of two common field methods in a moist tropical forest. Methods in Ecology and Evolution 2013, 4, 793-801 doi: 10.1111/2041-210X.12071

Maack, J., Lingenfelder, M., Weinacker, H., \& Koch, B. (2016). Modeling the standing timber volume of Baden-Württemberg-A large-scale approach using a fusion of Landsat, airborne LiDAR and National Forest Inventory data. International Journal of Applied Earth Observation and Geoinformation, 49, 107-116. doi:10.1016/j.jag.2016.02.004

Martinuzzi, S., Vierling, L. A., Gould, W. A., Falkowski, M. J., Evans, J. S., Hudak, A. T., \& Vierling, K. T. (2009). Mapping snags and understory shrubs for a 
LiDAR-based assessment of wildlife habitat suitability. Remote Sensing of Environment, 113(12), 2533-2546. doi:10.1016/j.rse.2009.07.002

McGaughey, R. J. (2016). FUSION/LDV: software for LiDAR data analysis and visualization.

Available from forsys.cfr.washington.edu/fusion/FUSION_manual.pdf [last accessed June 10, 2018].

Meteer, J. W. (1966). Butt log tree grades analyzed. Ford Forestry Center Research Note No. 2.

Mlodziansky, A.K. 1898. Measuring the forest crop. USDA For. Serv., Bull. 20, Forestry Division, Washington, DC. 71 p.

Neuendorff, J. K., Nagel, L. M., Webster, C. R., \& Janowiak, M. K. (2007). Stand structure and composition in a northern hardwood forest after 40 years of singletree selection. Northern Journal of Applied Forestry, 24, 197-202.

Ohmann, Janet L., \& Gregory, Matthew J. (2002). Predictive mapping of forest composition and structure with direct gradient analysis and nearest- neighbor imputation in coastal Oregon, U.S.A. Canadian Journal of Forest Research, 32(4), 725-741. doi:10.1139/x02-011

Ozkal, Mustafa Kagan, "MODELS OF FOREST INVENTORY FOR ISTANBUL FOREST USING AIRBORNE LiDAR AND SPACEBORNE IMAGERY", Open 
Access Master's Thesis, Michigan Technological University, 2017. http://digitalcommons.mtu.edu/etdr/371

Pandey S., \& Bright, C.L. (2008). What are degrees of Freedom? Soc Work Res, 2 pp. $119-128$

Popescu, S.C., Wynne, R.H., and Nelson, R.F. (2003). Measuring individual tree crown diameter with lidar and assessing its influence on estimating forest volume and biomass. Canadian Journal of Remote Sensing, Vol. 29, No. 5,pp. 564-577.

Popescu, S.C., and Wynne, R.H. (2004). Seeing the trees in the forest: using lidar and multispectral data fusion with local filtering and variable window size for estimating tree height. Photogrammetric Engineering \& Remote Sensing, Vol. 70, pp. 589-604.

Popescu, S.C. (2007). Estimating biomass of individual pine trees using airborne lidar. Biomass and Bioenergy. Volume 31, Issue 9, September 2007, Pages 646-655. https://doi.org/10.1016/j.biombioe.2007.06.022

RStudio Team (2016). RStudio: Integrated Development for R. RStudio, Inc., Boston, MA URL http://www.rstudio.com/.

Quantum Spatial, Inc. (2017). Michigan Hyperspectral and LiDAR Technical Data Report. 
Sasaki, N., Asner, G. P., Pan, Y., Knorr, W., Durst, P. B., Ma, H. O., Putz, F. E. (2016). Sustainable Management of Tropical Forests Can Reduce Carbon Emissions and Stabilize Timber Production. Frontiers in Environmental Science, 4.doi:10.3389/fenvs.2016.00050

Schlich, W., (1895). A manual of forestry. Vol. III. Forest management. Bradbury, Agnew, \& Company, London, UK. 397 p.

Schreuder, H.T., Gregoire, T.G. \& Wood, G.B. 1993. Sampling methods for multiresource forest inventory. New York, John Wiley \& Sons.

Singh, K. K., Bianchetti, R. A., Chen, G., \& Meentemeyer, R. K. (2016). Assessing effect of dominant land-cover types and pattern on urban forest biomass estimated using LiDAR metrics. Urban Ecosystems. doi:10.1007/s11252-0160591-8

Smith, W.R., Farrar Jr. R.M., Murphy, P.A., Yeiser, Y.L., Meldahl, R.S. et al. (1992) Crown and basal relationships of open-growth southern pines for modeling competition and growth. Canadian Journal of Forest Research, 22 (1992), pp. 341-347

Sprinz, P.T., Burkhart, H.E. (1987). Relationships between tree crown, stem, and stand characteristics in unthinned loblolly pine plantations. Canadian Journal of Forest Research, 17, pp. 534-538 
Running S. W., Nemani R. R., Heinsch F. A., Zhao M., Reeves M., Hashimoto H., (2004). A Continuous Satellite-Derived Measure of Global Terrestrial Primary Production, BioScience, Volume 54, Issue 6, Pages 547-560, https://doi.org/10.1641/00063568(2004)054[0547:ACSMOG]2.0.CO;2

Wang, Y., (2014). National Biomass Estimator Library. USDA Forest Service.

Wang, Y., (2017). Volume Estimator Library Equations. USDA Forest Service.

Wulder, M. A., Bater, C. W., Coops, N. C., Hilker, T., \& White, J. C. (2008). The role of LiDAR in sustainable forest management. The Forestry Chronicle, 84(6),807-826. 


\section{Appendix A}

Table 24. Height measurement comparisons between ground and LiDAR for 2017 dataset

\begin{tabular}{|c|c|c|c|c|c|}
\hline $\begin{array}{l}\text { Tree } \\
\text { ID }\end{array}$ & SSP & $\begin{array}{l}\text { DBH } \\
(\mathrm{cm})\end{array}$ & $\begin{array}{c}\text { Climbing } \\
\text { Measurements } \\
\text { (m) }\end{array}$ & $\begin{array}{c}\text { LiDAR height } \\
\text { Measurements(m) }\end{array}$ & $\begin{array}{c}\text { Lidar } \\
\text { Accuracy }\end{array}$ \\
\hline 4 & HW & 40.89 & 19.99 & 20.69 & $96.65 \%$ \\
\hline 5 & HW & 23.62 & 20.14 & 18.17 & $90.25 \%$ \\
\hline 7 & HW & 29.21 & 19.10 & 19.17 & $99.67 \%$ \\
\hline 10 & HW & 11.43 & 15.26 & 16.99 & $89.81 \%$ \\
\hline 11 & HW & 25.91 & 21.28 & 20.88 & $98.15 \%$ \\
\hline 13 & HW & 14.48 & 19.66 & 19.67 & $99.94 \%$ \\
\hline 14 & HW & 21.08 & 21.64 & 23.97 & $90.30 \%$ \\
\hline 15 & HW & 23.37 & 20.73 & 20.87 & $99.33 \%$ \\
\hline 16 & HW & 15.49 & 19.75 & 20.87 & $94.66 \%$ \\
\hline 17 & HW & 16.26 & 19.51 & 20.89 & $93.39 \%$ \\
\hline 18 & HW & 59.18 & 30.66 & 31.36 & $97.79 \%$ \\
\hline 27 & HW & 36.32 & 22.62 & 22.17 & $98.03 \%$ \\
\hline 28 & HW & 41.15 & 22.04 & 22.46 & $98.10 \%$ \\
\hline 30 & HW & 37.85 & 19.75 & 19.31 & $97.75 \%$ \\
\hline 31 & HW & 29.97 & 18.14 & 16.51 & $91.03 \%$ \\
\hline 47 & HW & 30.73 & 21.34 & 19.42 & $91.04 \%$ \\
\hline 49 & HW & 36.07 & 21.37 & 20.87 & $97.66 \%$ \\
\hline 51 & HW & 44.45 & 22.40 & 22.06 & $98.46 \%$ \\
\hline 53 & HW & 35.56 & 21.70 & 20.64 & $95.10 \%$ \\
\hline 55 & HW & 33.53 & 18.59 & 19.20 & $96.83 \%$ \\
\hline 73 & HW & 35.31 & 19.63 & 18.69 & $95.24 \%$ \\
\hline 74 & HW & 30.48 & 21.03 & 19.51 & $92.76 \%$ \\
\hline 75 & HW & 31.75 & 20.82 & 19.60 & $94.13 \%$ \\
\hline 76 & HW & 33.78 & 19.87 & 20.42 & $97.31 \%$ \\
\hline 77 & HW & 33.27 & 18.65 & 20.29 & $91.94 \%$ \\
\hline 82 & HW & 33.27 & 19.14 & 18.21 & $95.15 \%$ \\
\hline 83 & HW & 39.12 & 21.49 & 21.46 & $99.88 \%$ \\
\hline 92 & HW & 33.53 & 18.90 & 18.51 & $97.95 \%$ \\
\hline 96 & HW & 34.29 & 20.09 & 21.77 & $92.26 \%$ \\
\hline 100 & HW & 45.47 & 16.73 & 15.36 & $91.79 \%$ \\
\hline 104 & HW & 27.94 & 19.66 & 20.66 & $95.17 \%$ \\
\hline 105 & HW & 36.83 & 18.90 & 18.45 & $97.64 \%$ \\
\hline
\end{tabular}




$\begin{array}{cccccc}107 & \text { HW } & 45.97 & 24.93 & 24.10 & 96.65 \% \\ 109 & \text { HW } & 48.26 & 22.28 & 22.27 & 99.93 \% \\ 1 & \text { SW } & 33.02 & 19.82 & 20.25 & 97.90 \% \\ 2 & \text { SW } & 29.21 & 25.57 & 25.78 & 99.21 \% \\ 3 & \text { SW } & 41.15 & 24.96 & 24.18 & 96.86 \% \\ 6 & \text { SW } & 36.83 & 25.85 & 26.45 & 97.70 \% \\ 8 & \text { SW } & 29.21 & 27.74 & 27.47 & 99.04 \% \\ 9 & \text { SW } & 24.38 & 19.72 & 20.29 & 97.18 \% \\ 12 & \text { SW } & 29.21 & 20.39 & 19.51 & 95.67 \% \\ 19 & \text { SW } & 39.12 & 29.14 & 29.62 & 98.38 \% \\ 20 & \text { SW } & 26.67 & 19.20 & 18.18 & 94.68 \% \\ 21 & \text { SW } & 39.37 & 32.80 & 31.35 & 95.58 \% \\ 22 & \text { SW } & 49.02 & 28.71 & 28.48 & 99.20 \% \\ 24 & \text { SW } & 48.26 & 26.06 & 27.27 & 95.57 \% \\ 25 & \text { SW } & 38.35 & 24.57 & 23.82 & 96.97 \% \\ 26 & \text { SW } & 36.83 & 25.33 & 24.24 & 95.71 \% \\ 29 & \text { SW } & 26.67 & 16.34 & 17.92 & 91.16 \% \\ 32 & \text { SW } & 31.24 & 19.66 & 19.14 & 97.35 \% \\ 106 & \text { SW } & 58.93 & 21.95 & 22.31 & 98.39 \%\end{array}$

Table 25. Height measurement comparisons between laser hypsometer and LiDAR for 2017 dataset

\begin{tabular}{cccccc}
\hline $\begin{array}{c}\text { Tree } \\
\text { ID }\end{array}$ & SSP & $\begin{array}{c}\text { DBH } \\
\mathbf{( c m )}\end{array}$ & $\begin{array}{c}\text { Climbing } \\
\text { Measurements } \\
\mathbf{( m )}\end{array}$ & $\begin{array}{c}\text { Laser } \\
\text { Hypsometer } \\
\text { Measurements(m) }\end{array}$ & $\begin{array}{c}\text { Hypsometer } \\
\text { Accuracy }\end{array}$ \\
\hline 4 & HW & 40.89 & 19.99 & 22.10 & $90.47 \%$ \\
5 & HW & 23.62 & 20.14 & 18.04 & $89.56 \%$ \\
7 & HW & 29.21 & 19.1 & 18.06 & $94.55 \%$ \\
10 & HW & 11.43 & 15.26 & 17.03 & $89.61 \%$ \\
11 & HW & 25.91 & 21.28 & 20.31 & $95.45 \%$ \\
13 & HW & 14.48 & 19.66 & 19.63 & $99.86 \%$ \\
14 & HW & 21.08 & 21.64 & 22.33 & $96.93 \%$ \\
15 & HW & 23.37 & 20.73 & 23.47 & $88.32 \%$ \\
16 & HW & 15.49 & 19.75 & 21.73 & $90.88 \%$ \\
17 & HW & 16.26 & 19.51 & 21.12 & $92.38 \%$ \\
18 & HW & 59.18 & 30.66 & 25.59 & $83.45 \%$
\end{tabular}




\begin{tabular}{|c|c|c|c|c|c|}
\hline 27 & HW & 36.32 & 22.62 & 24.86 & $90.98 \%$ \\
\hline 28 & HW & 41.15 & 22.04 & 21.94 & $99.52 \%$ \\
\hline 30 & HW & 37.85 & 19.75 & 20.59 & $95.94 \%$ \\
\hline 31 & HW & 29.97 & 18.14 & 18.20 & $99.68 \%$ \\
\hline 47 & HW & 30.73 & 21.34 & 19.11 & $89.54 \%$ \\
\hline 49 & HW & 36.07 & 21.37 & 20.50 & $95.93 \%$ \\
\hline 51 & HW & 44.45 & 22.4 & 20.59 & $91.91 \%$ \\
\hline 53 & HW & 35.56 & 21.7 & 22.15 & $97.97 \%$ \\
\hline 55 & HW & 33.53 & 18.59 & 23.25 & $79.97 \%$ \\
\hline 73 & HW & 35.31 & 19.63 & 18.70 & $95.24 \%$ \\
\hline 74 & HW & 30.48 & 21.03 & 21.11 & $99.61 \%$ \\
\hline 75 & HW & 31.75 & 20.82 & 21.07 & $98.83 \%$ \\
\hline 76 & HW & 33.78 & 19.87 & 22.11 & $89.86 \%$ \\
\hline 77 & HW & 33.27 & 18.65 & 18.61 & $99.79 \%$ \\
\hline 82 & HW & 33.27 & 19.14 & 20.89 & $91.61 \%$ \\
\hline 83 & HW & 39.12 & 21.49 & 23.47 & $91.56 \%$ \\
\hline 92 & HW & 33.53 & 18.9 & 19.79 & $95.51 \%$ \\
\hline 96 & HW & 34.29 & 20.09 & 19.14 & $95.25 \%$ \\
\hline 100 & HW & 45.47 & 16.73 & 17.59 & $95.10 \%$ \\
\hline 104 & HW & 27.94 & 19.66 & 18.74 & $95.32 \%$ \\
\hline 105 & HW & 36.83 & 18.9 & 20.25 & $93.34 \%$ \\
\hline 107 & HW & 45.97 & 24.93 & 23.83 & $95.60 \%$ \\
\hline 109 & HW & 48.26 & 22.28 & 24.00 & $92.82 \%$ \\
\hline 1 & SW & 33.02 & 19.82 & 22.86 & $86.72 \%$ \\
\hline 2 & SW & 29.21 & 25.57 & 23.92 & $93.54 \%$ \\
\hline 3 & SW & 41.15 & 24.96 & 26.78 & $93.22 \%$ \\
\hline 6 & SW & 36.83 & 25.85 & 25.10 & $97.10 \%$ \\
\hline 8 & SW & 29.21 & 27.74 & 26.52 & $95.59 \%$ \\
\hline 9 & SW & 24.38 & 19.72 & 20.47 & $96.35 \%$ \\
\hline 12 & SW & 29.21 & 20.39 & 25.49 & $79.98 \%$ \\
\hline 19 & SW & 39.12 & 29.14 & 25.59 & $87.81 \%$ \\
\hline 20 & SW & 26.67 & 19.2 & 18.72 & $97.47 \%$ \\
\hline 21 & SW & 39.37 & 32.8 & 27.24 & $83.03 \%$ \\
\hline 22 & SW & 49.02 & 28.71 & 24.04 & $83.73 \%$ \\
\hline 24 & SW & 48.26 & 26.06 & 24.23 & $92.98 \%$ \\
\hline 25 & SW & 38.35 & 24.57 & 24.36 & $99.12 \%$ \\
\hline 26 & SW & 36.83 & 25.33 & 25.81 & $98.16 \%$ \\
\hline 29 & SW & 26.67 & 16.34 & 17.19 & $95.08 \%$ \\
\hline 32 & SW & 31.24 & 19.66 & 18.78 & $95.50 \%$ \\
\hline 106 & SW & 58.93 & 21.95 & 23.67 & $92.73 \%$ \\
\hline
\end{tabular}




\section{Appendix B}

Table 26. Testing 2017 equation on 2017 data

\begin{tabular}{|c|c|c|c|c|c|c|c|}
\hline $\begin{array}{c}\text { Tree } \\
\text { ID }\end{array}$ & Wood & $\begin{array}{c}\text { Predicted } \\
\text { DBH of } \\
2011 \text { by } \\
\text { using } \\
2017 \text { (ŷi) }\end{array}$ & $\begin{array}{c}\text { DBH } \\
2011(y i)\end{array}$ & $\mathbf{H t}$ & ei (yi-ŷi) & $\mathbf{e i}^{2}$ & $\mid$ ei $\mid$ \\
\hline 4 & HW & 31.01 & 40.89 & 20.69 & 9.89 & 97.73 & 9.89 \\
\hline 5 & HW & 20.93 & 23.62 & 18.17 & 2.69 & 7.24 & 2.69 \\
\hline 7 & HW & 26.68 & 29.21 & 19.17 & 2.53 & 6.40 & 2.53 \\
\hline 10 & HW & 12.34 & 11.43 & 16.99 & -0.91 & 0.84 & 0.91 \\
\hline 11 & HW & 29.33 & 25.91 & 20.88 & -3.42 & 11.71 & 3.42 \\
\hline 13 & HW & 25.93 & 14.48 & 19.67 & -11.46 & 131.25 & 11.46 \\
\hline 14 & HW & 28.99 & 21.08 & 23.97 & -7.91 & 62.57 & 7.91 \\
\hline 15 & HW & 29.32 & 23.37 & 20.87 & -5.95 & 35.45 & 5.95 \\
\hline 16 & HW & 27.75 & 15.49 & 20.87 & -12.25 & 150.18 & 12.25 \\
\hline 17 & HW & 27.24 & 16.26 & 20.89 & -10.99 & 120.72 & 10.99 \\
\hline 18 & HW & 45.91 & 59.18 & 31.36 & 13.27 & 176.20 & 13.27 \\
\hline 27 & HW & 31.81 & 36.32 & 22.17 & 4.51 & 20.35 & 4.51 \\
\hline 28 & HW & 30.39 & 41.15 & 22.46 & 10.76 & 115.71 & 10.76 \\
\hline 30 & HW & 32.44 & 37.85 & 19.31 & 5.41 & 29.23 & 5.41 \\
\hline 31 & HW & 26.60 & 29.97 & 16.51 & 3.38 & 11.40 & 3.38 \\
\hline 47 & HW & 38.76 & 30.73 & 19.42 & -8.03 & 64.48 & 8.03 \\
\hline 49 & HW & 42.00 & 36.07 & 20.87 & -5.93 & 35.17 & 5.93 \\
\hline 51 & HW & 45.92 & 44.45 & 22.06 & -1.47 & 2.16 & 1.47 \\
\hline 53 & HW & 32.57 & 35.56 & 20.64 & 2.99 & 8.96 & 2.99 \\
\hline 55 & HW & 34.46 & 33.53 & 19.20 & -0.94 & 0.88 & 0.94 \\
\hline 73 & HW & 34.25 & 35.31 & 18.69 & 1.06 & 1.12 & 1.06 \\
\hline 74 & HW & 36.76 & 30.48 & 19.51 & -6.28 & 39.44 & 6.28 \\
\hline 75 & HW & 34.28 & 31.75 & 19.60 & -2.53 & 6.41 & 2.53 \\
\hline 76 & HW & 38.61 & 33.78 & 20.42 & -4.82 & 23.26 & 4.82 \\
\hline 77 & HW & 34.92 & 33.27 & 20.29 & -1.65 & 2.71 & 1.65 \\
\hline 82 & HW & 38.15 & 33.27 & 18.21 & -4.87 & 23.75 & 4.87 \\
\hline 83 & HW & 31.88 & 39.12 & 21.46 & 7.23 & 52.34 & 7.23 \\
\hline 92 & HW & 29.84 & 33.53 & 18.51 & 3.69 & 13.64 & 3.69 \\
\hline 96 & HW & 34.97 & 34.29 & 21.77 & -0.68 & 0.47 & 0.68 \\
\hline 100 & HW & 35.85 & 45.47 & 15.36 & 9.62 & 92.51 & 9.62 \\
\hline
\end{tabular}




$\begin{array}{cccccccc}104 & \text { HW } & 37.30 & 27.94 & 20.66 & -9.36 & 87.64 & 9.36 \\ 105 & \text { HW } & 36.39 & 36.83 & 18.45 & 0.44 & 0.20 & 0.44 \\ 107 & \text { HW } & 41.88 & 45.97 & 24.10 & 4.10 & 16.79 & 4.10 \\ 109 & \text { HW } & 49.63 & 48.26 & 22.27 & -1.37 & 1.88 & 1.37 \\ 1 & \text { SW } & 26.86 & 33.02 & 20.25 & 6.16 & 37.99 & 6.16 \\ 2 & \text { SW } & 35.27 & 29.21 & 25.78 & -6.06 & 36.77 & 6.06 \\ 3 & \text { SW } & 36.56 & 41.15 & 24.18 & 4.58 & 21.01 & 4.58 \\ 6 & \text { SW } & 36.37 & 36.83 & 26.45 & 0.46 & 0.22 & 0.46 \\ 8 & \text { SW } & 39.98 & 29.21 & 27.47 & -10.77 & 116.02 & 10.77 \\ 9 & \text { SW } & 20.86 & 24.38 & 20.29 & 3.52 & 12.41 & 3.52 \\ 12 & \text { SW } & 23.28 & 29.21 & 19.51 & 5.93 & 35.14 & 5.93 \\ 19 & \text { SW } & 42.70 & 39.12 & 29.62 & -3.58 & 12.85 & 3.58 \\ 20 & \text { SW } & 28.50 & 26.67 & 18.18 & -1.83 & 3.33 & 1.83 \\ 21 & \text { SW } & 46.31 & 39.37 & 31.35 & -6.94 & 48.16 & 6.94 \\ 22 & \text { SW } & 48.62 & 49.02 & 28.48 & 0.41 & 0.17 & 0.41 \\ 24 & \text { SW } & 44.58 & 48.26 & 27.27 & 3.68 & 13.56 & 3.68 \\ 25 & \text { SW } & 31.91 & 38.35 & 23.82 & 6.44 & 41.52 & 6.44 \\ 26 & \text { SW } & 31.91 & 36.83 & 24.24 & 4.92 & 24.19 & 4.92 \\ 29 & \text { SW } & 28.02 & 26.67 & 17.92 & -1.35 & 1.84 & 1.35 \\ 32 & \text { SW } & 31.72 & 31.24 & 19.14 & -0.48 & 0.23 & 0.48 \\ 106 & \text { SW } & 44.77 & 58.93 & 22.31 & 14.16 & 200.57 & 14.16\end{array}$

Table 27. Testing 2017 equation on 2011 data

\begin{tabular}{|c|c|c|c|c|c|c|c|}
\hline $\begin{array}{c}\text { Tree } \\
\text { ID }\end{array}$ & Wood & 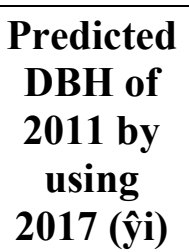 & $\begin{array}{c}\text { DBH } \\
2011(y i)\end{array}$ & $\mathbf{H t}$ & ei (yi-ŷi) & $\mathbf{e i}^{2}$ & $|\mathbf{e i}|$ \\
\hline 4 & HW & 30.80 & 38.29 & 19.23 & 7.49 & 56.12 & 7.49 \\
\hline 5 & HW & 26.60 & 21.38 & 21.07 & -5.22 & 27.25 & 5.22 \\
\hline 7 & HW & 22.63 & 26.71 & 18.99 & 4.08 & 16.66 & 4.08 \\
\hline 10 & HW & 15.36 & 6.45 & 14.36 & -8.90 & 79.29 & 8.90 \\
\hline 11 & HW & 23.74 & 22.58 & 17.98 & -1.16 & 1.34 & 1.16 \\
\hline 13 & HW & 20.53 & 8.78 & 17.96 & -11.76 & 138.23 & 11.76 \\
\hline 14 & HW & 23.90 & 16.52 & 19.00 & -7.38 & 54.42 & 7.38 \\
\hline 15 & HW & 25.55 & 17.96 & 21.50 & -7.59 & 57.58 & 7.59 \\
\hline 16 & HW & 21.45 & 12.04 & 19.01 & -9.41 & 88.52 & 9.41 \\
\hline 17 & HW & 19.67 & 14.11 & 19.22 & -5.56 & 30.91 & 5.56 \\
\hline 18 & HW & 42.16 & 51.21 & 29.94 & 9.05 & 81.92 & 9.05 \\
\hline 27 & HW & 33.22 & 33.59 & 22.23 & 0.37 & 0.14 & 0.37 \\
\hline
\end{tabular}




$\begin{array}{cccccccc}28 & \text { HW } & 23.45 & 37.47 & 21.13 & 14.02 & 196.54 & 14.02 \\ 30 & \text { HW } & 30.11 & 35.86 & 18.92 & 5.75 & 33.10 & 5.75 \\ 31 & \text { HW } & 26.02 & 27.51 & 17.44 & 1.49 & 2.22 & 1.49 \\ 47 & \text { HW } & 30.82 & 26.36 & 19.55 & -4.46 & 19.88 & 4.46 \\ 49 & \text { HW } & 31.38 & 30.63 & 20.50 & -0.75 & 0.56 & 0.75 \\ 51 & \text { HW } & 34.70 & 39.70 & 21.08 & 5.00 & 25.02 & 5.00 \\ 53 & \text { HW } & 30.90 & 31.31 & 20.71 & 0.40 & 0.16 & 0.40 \\ 55 & \text { HW } & 28.22 & 29.30 & 17.48 & 1.09 & 1.19 & 1.09 \\ 73 & \text { HW } & 26.85 & 31.21 & 19.18 & 4.36 & 18.98 & 4.36 \\ 74 & \text { HW } & 36.71 & 26.26 & 20.23 & -10.45 & 109.22 & 10.45 \\ 75 & \text { HW } & 36.86 & 27.80 & 20.03 & -9.06 & 82.03 & 9.06 \\ 76 & \text { HW } & 25.93 & 31.50 & 18.73 & 5.57 & 31.07 & 5.57 \\ 77 & \text { HW } & 30.64 & 31.45 & 17.87 & 0.81 & 0.66 & 0.81 \\ 82 & \text { HW } & 40.73 & 27.32 & 18.35 & -13.41 & 179.74 & 13.41 \\ 83 & \text { HW } & 24.51 & 35.60 & 20.82 & 11.09 & 122.98 & 11.09 \\ 92 & \text { HW } & 24.33 & 30.76 & 17.93 & 6.43 & 41.30 & 6.43 \\ 96 & \text { HW } & 24.86 & 29.83 & 19.51 & 4.96 & 24.65 & 4.96 \\ 100 & \text { HW } & 31.84 & 39.92 & 15.87 & 8.07 & 65.14 & 8.07 \\ 104 & \text { HW } & 35.82 & 24.67 & 19.23 & -11.15 & 124.41 & 11.15 \\ 105 & \text { HW } & 34.19 & 34.43 & 18.35 & 0.24 & 0.06 & 0.24 \\ 107 & \text { HW } & 38.56 & 42.28 & 23.83 & 3.72 & 13.84 & 3.72 \\ 109 & \text { HW } & 37.47 & 46.06 & 20.50 & 8.60 & 73.90 & 8.60 \\ 1 & \text { SW } & 27.34 & 31.06 & 22.57 & 3.72 & 13.82 & 3.72 \\ 2 & \text { SW } & 38.03 & 26.34 & 24.46 & -11.69 & 136.60 & 11.69 \\ 3 & \text { SW } & 33.30 & 37.97 & 24.14 & 4.66 & 21.76 & 4.66 \\ 6 & \text { SW } & 32.61 & 33.14 & 23.58 & 0.53 & 0.28 & 0.53 \\ 8 & \text { SW } & 33.97 & 26.76 & 26.40 & -7.21 & 52.04 & 7.21 \\ 9 & \text { SW } & 21.22 & 18.08 & 17.96 & -3.14 & 9.84 & 3.14 \\ 12 & \text { SW } & 25.41 & 25.60 & 19.00 & 0.19 & 0.03 & 0.19 \\ 19 & \text { SW } & 39.14 & 36.02 & 27.65 & -3.12 & 9.73 & 3.12 \\ 20 & \text { SW } & 21.47 & 21.14 & 17.99 & -0.33 & 0.11 & 0.33 \\ 21 & \text { SW } & 42.99 & 37.04 & 30.20 & -5.95 & 35.43 & 5.95 \\ 22 & \text { SW } & 43.02 & 40.96 & 28.50 & -2.06 & 4.24 & 2.06 \\ 24 & \text { SW } & 40.78 & 43.14 & 24.49 & 2.37 & 5.61 & 2.37 \\ 25 & \text { SW } & 30.09 & 36.21 & 22.54 & 6.12 & 37.47 & 6.12 \\ 26 & \text { SW } & 33.74 & 34.08 & 24.48 & 0.34 & 0.11 & 0.34 \\ 29 & \text { SW } & 20.24 & 24.41 & 15.93 & 4.17 & 17.40 & 4.17 \\ 32 & \text { SW } & 22.95 & 25.65 & 17.04 & 2.70 & 7.29 & 2.70 \\ 106 & \text { SW } & 42.02 & 54.38 & 19.55 & 12.35 & 152.64 & 12.35 \\ & & & & & & & \end{array}$


Table 28 Testing 2011 equation on 2011 data

\begin{tabular}{|c|c|c|c|c|c|c|c|}
\hline $\begin{array}{c}\text { Tree } \\
\text { ID }\end{array}$ & Wood & 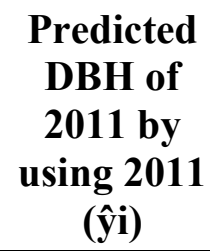 & $\begin{array}{c}\text { DBH } \\
2011(y i)\end{array}$ & $\mathbf{H t}$ & ei $(y \mathbf{i}-\hat{y} \mathbf{i})$ & $\mathbf{e i}^{2}$ & $|\mathbf{e i}|$ \\
\hline 4 & HW & 31.16 & 38.29 & 19.23 & 7.13 & 50.86 & 7.13 \\
\hline 5 & HW & 26.16 & 21.38 & 21.07 & -4.78 & 22.90 & 4.78 \\
\hline 7 & HW & 21.68 & 26.71 & 18.99 & 5.03 & 25.31 & 5.03 \\
\hline 10 & HW & 18.91 & 6.45 & 14.36 & -12.46 & 155.22 & 12.46 \\
\hline 11 & HW & 25.58 & 22.58 & 17.98 & -3.00 & 9.00 & 3.00 \\
\hline 13 & HW & 20.27 & 8.78 & 17.96 & -11.49 & 132.11 & 11.49 \\
\hline 14 & HW & 25.17 & 16.52 & 19.00 & -8.65 & 74.75 & 8.65 \\
\hline 15 & HW & 23.30 & 17.96 & 21.50 & -5.34 & 28.55 & 5.34 \\
\hline 16 & HW & 22.48 & 12.04 & 19.01 & -10.44 & 109.03 & 10.44 \\
\hline 17 & HW & 19.96 & 14.11 & 19.22 & -5.85 & 34.20 & 5.85 \\
\hline 18 & HW & 41.33 & 51.21 & 29.94 & 9.88 & 97.56 & 9.88 \\
\hline 27 & HW & 33.03 & 33.59 & 22.23 & 0.56 & 0.31 & 0.56 \\
\hline 28 & HW & 23.19 & 37.47 & 21.13 & 14.28 & 203.89 & 14.28 \\
\hline 30 & HW & 30.26 & 35.86 & 18.92 & 5.61 & 31.42 & 5.61 \\
\hline 31 & HW & 25.71 & 27.51 & 17.44 & 1.80 & 3.24 & 1.80 \\
\hline 47 & HW & 31.90 & 26.36 & 19.55 & -5.54 & 30.69 & 5.54 \\
\hline 49 & HW & 31.95 & 30.63 & 20.50 & -1.32 & 1.74 & 1.32 \\
\hline 51 & HW & 35.83 & 39.70 & 21.08 & 3.87 & 14.99 & 3.87 \\
\hline 53 & HW & 31.38 & 31.31 & 20.71 & -0.08 & 0.01 & 0.08 \\
\hline 55 & HW & 28.03 & 29.30 & 17.48 & 1.27 & 1.62 & 1.27 \\
\hline 73 & HW & 28.21 & 31.21 & 19.18 & 3.00 & 9.02 & 3.00 \\
\hline 74 & HW & 36.71 & 26.26 & 20.23 & -10.45 & 109.20 & 10.45 \\
\hline 75 & HW & 36.34 & 27.80 & 20.03 & -8.53 & 72.80 & 8.53 \\
\hline 76 & HW & 28.48 & 31.50 & 18.73 & 3.02 & 9.12 & 3.02 \\
\hline 77 & HW & 29.37 & 31.45 & 17.87 & 2.08 & 4.31 & 2.08 \\
\hline 82 & HW & 38.84 & 27.32 & 18.35 & -11.51 & 132.57 & 11.51 \\
\hline 83 & HW & 22.38 & 35.60 & 20.82 & 13.21 & 174.54 & 13.21 \\
\hline 92 & HW & 24.58 & 30.76 & 17.93 & 6.17 & 38.12 & 6.17 \\
\hline 96 & HW & 27.38 & 29.83 & 19.51 & 2.45 & 6.02 & 2.45 \\
\hline 100 & HW & 33.51 & 39.92 & 15.87 & 6.41 & 41.07 & 6.41 \\
\hline 104 & HW & 37.25 & 24.67 & 19.23 & -12.59 & 158.40 & 12.59 \\
\hline 105 & HW & 34.40 & 34.43 & 18.35 & 0.04 & 0.00 & 0.04 \\
\hline 107 & HW & 39.33 & 42.28 & 23.83 & 2.95 & 8.70 & 2.95 \\
\hline 109 & HW & 35.80 & 46.06 & 20.50 & 10.27 & 105.40 & 10.27 \\
\hline
\end{tabular}




$\begin{array}{cccccccc}1 & \text { SW } & 26.05 & 31.06 & 22.57 & 5.01 & 25.10 & 5.01 \\ 2 & \text { SW } & 36.65 & 26.34 & 24.46 & -10.30 & 106.12 & 10.30 \\ 3 & \text { SW } & 33.17 & 37.97 & 24.14 & 4.79 & 22.97 & 4.79 \\ 6 & \text { SW } & 32.76 & 33.14 & 23.58 & 0.38 & 0.14 & 0.38 \\ 8 & \text { SW } & 32.91 & 26.76 & 26.40 & -6.16 & 37.90 & 6.16 \\ 9 & \text { SW } & 20.83 & 18.08 & 17.96 & -2.75 & 7.56 & 2.75 \\ 12 & \text { SW } & 27.79 & 25.60 & 19.00 & -2.20 & 4.82 & 2.20 \\ 19 & \text { SW } & 38.45 & 36.02 & 27.65 & -2.43 & 5.92 & 2.43 \\ 20 & \text { SW } & 22.90 & 21.14 & 17.99 & -1.75 & 3.08 & 1.75 \\ 21 & \text { SW } & 43.51 & 37.04 & 30.20 & -6.47 & 41.90 & 6.47 \\ 22 & \text { SW } & 41.88 & 40.96 & 28.50 & -0.91 & 0.83 & 0.91 \\ 24 & \text { SW } & 40.16 & 43.14 & 24.49 & 2.99 & 8.91 & 2.99 \\ 25 & \text { SW } & 29.66 & 36.21 & 22.54 & 6.55 & 42.90 & 6.55 \\ 26 & \text { SW } & 31.99 & 34.08 & 24.48 & 2.09 & 4.37 & 2.09 \\ 29 & \text { SW } & 21.06 & 24.41 & 15.93 & 3.35 & 11.21 & 3.35 \\ 32 & \text { SW } & 25.08 & 25.65 & 17.04 & 0.58 & 0.33 & 0.58 \\ 106 & \text { SW } & 41.40 & 54.38 & 19.55 & 12.98 & 168.60 & 12.98\end{array}$

Table 29. Testing 2011 equation on 2017 data

\begin{tabular}{|c|c|c|c|c|c|c|c|}
\hline $\begin{array}{c}\text { Tree } \\
\text { ID }\end{array}$ & Wood & 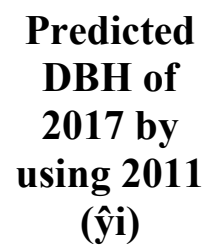 & $\begin{array}{c}\text { DBH } \\
2017(y i)\end{array}$ & $\mathbf{H t}$ & ei (yi-ŷi) & $\mathbf{e i}^{2}$ & $|\mathbf{e i}|$ \\
\hline 4 & HW & 31.16 & 40.89 & 20.69 & 9.73 & 94.75 & 9.73 \\
\hline 5 & HW & 21.98 & 23.62 & 18.17 & 1.64 & 2.68 & 1.64 \\
\hline 7 & HW & 28.34 & 29.21 & 19.17 & 0.87 & 0.76 & 0.87 \\
\hline 10 & HW & 11.75 & 11.43 & 16.99 & -0.32 & 0.11 & 0.32 \\
\hline 11 & HW & 29.28 & 25.91 & 20.88 & -3.37 & 11.39 & 3.37 \\
\hline 13 & HW & 26.93 & 14.48 & 19.67 & -12.45 & 155.08 & 12.45 \\
\hline 14 & HW & 31.99 & 21.08 & 23.97 & -10.91 & 119.05 & 10.91 \\
\hline 15 & HW & 27.92 & 23.37 & 20.87 & -4.55 & 20.68 & 4.55 \\
\hline 16 & HW & 27.74 & 15.49 & 20.87 & -12.24 & 149.85 & 12.24 \\
\hline 17 & HW & 26.56 & 16.26 & 20.89 & -10.31 & 106.21 & 10.31 \\
\hline 18 & HW & 44.12 & 59.18 & 31.36 & 15.06 & 226.85 & 15.06 \\
\hline 27 & HW & 32.66 & 36.32 & 22.17 & 3.66 & 13.40 & 3.66 \\
\hline 28 & HW & 30.15 & 41.15 & 22.46 & 11.00 & 120.95 & 11.00 \\
\hline 30 & HW & 33.41 & 37.85 & 19.31 & 4.43 & 19.66 & 4.43 \\
\hline
\end{tabular}




$\begin{array}{cccccccc}31 & \text { HW } & 26.75 & 29.97 & 16.51 & 3.22 & 10.35 & 3.22 \\ 47 & \text { HW } & 38.12 & 30.73 & 19.42 & -7.38 & 54.52 & 7.38 \\ & & & & & & & \\ 49 & \text { HW } & 41.61 & 36.07 & 20.87 & -5.54 & 30.66 & 5.54 \\ 51 & \text { HW } & 45.26 & 44.45 & 22.06 & -0.81 & 0.65 & 0.81 \\ 53 & \text { HW } & 34.07 & 35.56 & 20.64 & 1.49 & 2.22 & 1.49 \\ 55 & \text { HW } & 33.35 & 33.53 & 19.20 & 0.18 & 0.03 & 0.18 \\ 73 & \text { HW } & 32.81 & 35.31 & 18.69 & 2.50 & 6.25 & 2.50 \\ 74 & \text { HW } & 35.63 & 30.48 & 19.51 & -5.15 & 26.53 & 5.15 \\ 75 & \text { HW } & 32.53 & 31.75 & 19.60 & -0.78 & 0.60 & 0.78 \\ 76 & \text { HW } & 37.54 & 33.78 & 20.42 & -3.75 & 14.10 & 3.75 \\ 77 & \text { HW } & 32.52 & 33.27 & 20.29 & 0.76 & 0.57 & 0.76 \\ 82 & \text { HW } & 37.91 & 33.27 & 18.21 & -4.64 & 21.49 & 4.64 \\ 83 & \text { HW } & 28.96 & 39.12 & 21.46 & 10.15 & 103.12 & 10.15 \\ 92 & \text { HW } & 28.31 & 33.53 & 18.51 & 5.22 & 27.25 & 5.22 \\ 96 & \text { HW } & 32.09 & 34.29 & 21.77 & 2.20 & 4.84 & 2.20 \\ 100 & \text { HW } & 36.06 & 45.47 & 15.36 & 9.41 & 88.51 & 9.41 \\ 104 & \text { HW } & 36.00 & 27.94 & 20.66 & -8.06 & 65.03 & 8.06 \\ 105 & \text { HW } & 35.64 & 36.83 & 18.45 & 1.19 & 1.41 & 1.19 \\ 107 & \text { HW } & 41.76 & 45.97 & 24.10 & 4.21 & 17.72 & 4.21 \\ 109 & \text { HW } & 50.69 & 48.26 & 22.27 & -2.43 & 5.92 & 2.43 \\ 1 & \text { SW } & 26.90 & 33.02 & 20.25 & 6.12 & 37.43 & 6.12 \\ 2 & \text { SW } & 35.01 & 29.21 & 25.78 & -5.80 & 33.61 & 5.80 \\ 3 & \text { SW } & 35.65 & 41.15 & 24.18 & 5.49 & 30.19 & 5.49 \\ 6 & \text { SW } & 37.51 & 36.83 & 26.45 & -0.68 & 0.46 & 0.68 \\ 8 & \text { SW } & 41.50 & 29.21 & 27.47 & -12.29 & 150.99 & 12.29 \\ 9 & \text { SW } & 20.79 & 24.38 & 20.29 & 3.59 & 12.90 & 3.59 \\ 12 & \text { SW } & 25.18 & 29.21 & 19.51 & 4.03 & 16.23 & 4.03 \\ 19 & \text { SW } & 43.54 & 39.12 & 29.62 & -4.42 & 19.54 & 4.42 \\ 20 & \text { SW } & 32.25 & 26.67 & 18.18 & -5.58 & 31.18 & 5.58 \\ 21 & \text { SW } & 46.08 & 39.37 & 31.35 & -6.71 & 44.98 & 6.71 \\ 22 & \text { SW } & 47.95 & 49.02 & 28.48 & 1.07 & 1.15 & 1.07 \\ 24 & \text { SW } & 45.47 & 48.26 & 27.27 & 2.79 & 7.77 & 2.79 \\ 25 & \text { SW } & 32.73 & 38.35 & 23.82 & 5.62 & 31.63 & 5.62 \\ 26 & \text { SW } & 32.53 & 36.83 & 24.24 & 4.30 & 18.50 & 4.30 \\ 29 & \text { SW } & 29.59 & 26.67 & 17.92 & -2.92 & 8.51 & 2.92 \\ 106 & \text { SW } & 33.40 & 31.24 & 19.14 & -2.16 & 4.65 & 2.16 \\ & \text { SW } & 45.62 & 58.93 & 22.31 & 13.31 & 177.23 & 13.31\end{array}$




\section{Appendix C}

\section{Estimated Volume and Biomass by Using Ground Measured Data}

Table 30. Estimated 2017 Volume

\begin{tabular}{|c|c|c|c|c|c|}
\hline Tree ID & Species & Wood & $\begin{array}{c}\text { DBH } \\
(\mathrm{cm})\end{array}$ & $\begin{array}{c}\text { Height } \\
\text { (m) }\end{array}$ & $\begin{array}{c}\text { Merchantable } \\
\text { Volume }\left(\mathrm{m}^{3}\right)\end{array}$ \\
\hline 4 & Red Oak & HW & 40.89 & 20.69 & 0.87 \\
\hline 5 & Red Oak & HW & 23.62 & 18.17 & 0.00 \\
\hline 7 & Red Oak & HW & 29.21 & 19.17 & 0.26 \\
\hline 10 & Sugar Maple & HW & 11.43 & 16.99 & 0.00 \\
\hline 11 & Sugar Maple & HW & 25.91 & 20.88 & 0.00 \\
\hline 13 & Sugar Maple & HW & 14.48 & 19.67 & 0.00 \\
\hline 14 & White Birch & HW & 21.08 & 23.97 & 0.00 \\
\hline 15 & Red Oak & HW & 23.37 & 20.87 & 0.00 \\
\hline 16 & Aspen & HW & 15.49 & 20.87 & 0.00 \\
\hline 17 & Sugar Maple & HW & 16.26 & 20.89 & 0.00 \\
\hline 18 & White Birch & HW & 59.18 & 31.36 & 3.02 \\
\hline 27 & Red Oak & HW & 36.32 & 22.17 & 0.57 \\
\hline 28 & Red Oak & HW & 41.15 & 22.46 & 0.88 \\
\hline 30 & Red Oak & HW & 37.85 & 19.31 & 0.61 \\
\hline 31 & Red Oak & HW & 29.97 & 16.51 & 0.16 \\
\hline 47 & Sugar Maple & HW & 30.73 & 19.42 & 0.30 \\
\hline 49 & Sugar Maple & HW & 36.07 & 20.87 & 0.57 \\
\hline 51 & Sugar Maple & HW & 44.45 & 22.06 & 1.02 \\
\hline 53 & Sugar Maple & HW & 35.56 & 20.64 & 0.55 \\
\hline 55 & Sugar Maple & HW & 33.53 & 19.20 & 0.36 \\
\hline 73 & Sugar Maple & HW & 35.31 & 18.69 & 0.54 \\
\hline 74 & Sugar Maple & HW & 30.48 & 19.51 & 0.29 \\
\hline 75 & Sugar Maple & HW & 31.75 & 19.60 & 0.32 \\
\hline 76 & Sugar Maple & HW & 33.78 & 20.42 & 0.50 \\
\hline 77 & Sugar Maple & HW & 33.27 & 20.29 & 0.48 \\
\hline 82 & Sugar Maple & HW & 33.27 & 18.21 & 0.35 \\
\hline 83 & Red Oak & HW & 39.12 & 21.46 & 0.80 \\
\hline 92 & Yellow Birch & HW & 33.53 & 18.51 & 0.35 \\
\hline 96 & Sugar Maple & HW & 34.29 & 21.77 & 0.51 \\
\hline 100 & Yellow Birch & HW & 45.47 & 15.36 & 0.85 \\
\hline 104 & Sugar Maple & HW & 27.94 & 20.66 & 0.14 \\
\hline
\end{tabular}




$\begin{array}{cccccc}105 & \text { Sugar Maple } & \text { HW } & 36.83 & 18.45 & 0.59 \\ 107 & \text { Sugar Maple } & \text { HW } & 45.97 & 24.10 & 1.30 \\ 109 & \text { Sugar Maple } & \text { HW } & 48.26 & 22.27 & 1.43 \\ 1 & \text { Red Pine } & \text { SW } & 33.02 & 20.25 & 0.57 \\ 2 & \text { Red Pine } & \text { SW } & 29.21 & 25.78 & 0.53 \\ 3 & \text { White Pine } & \text { SW } & 41.15 & 24.18 & 0.96 \\ 6 & \text { Eastern Hemlock } & \text { SW } & 36.83 & 26.45 & 0.92 \\ 8 & \text { Red Pine } & \text { SW } & 29.21 & 27.47 & 0.53 \\ 9 & \text { White Pine } & \text { SW } & 24.38 & 20.29 & 0.18 \\ 12 & \text { Red Pine } & \text { SW } & 29.21 & 19.51 & 0.44 \\ 19 & \text { Red Pine } & \text { SW } & 39.12 & 29.62 & 1.16 \\ 20 & \text { White Pine } & \text { SW } & 26.67 & 18.18 & 0.22 \\ 21 & \text { Red Pine } & \text { SW } & 39.37 & 31.35 & 1.29 \\ 22 & \text { White Pine } & \text { SW } & 49.02 & 28.48 & 1.75 \\ 23 & \text { White Pine } & \text { SW } & 39.12 & 16.14 & 0.58 \\ 24 & \text { Red Pine } & \text { SW } & 48.26 & 27.27 & 1.76 \\ 25 & \text { Red Pine } & \text { SW } & 38.35 & 23.82 & 1.00 \\ 26 & \text { Red Pine } & \text { SW } & 36.83 & 24.24 & 0.96 \\ 29 & \text { Red Pine } & \text { SW } & 26.67 & 17.92 & 0.29 \\ 32 & \text { Red Pine } & \text { SW } & 31.24 & 19.14 & 0.51 \\ 106 & \text { Eastern Hemlock } & \text { SW } & 58.93 & 22.31 & 2.35\end{array}$

Table 31. Estimated 2011 Volume

\begin{tabular}{cccccc}
\hline Tree ID & Species & Wood & $\begin{array}{c}\text { DBH } \\
(\mathbf{c m})\end{array}$ & $\begin{array}{c}\text { Height } \\
(\mathbf{m})\end{array}$ & $\begin{array}{c}\text { Merchantable } \\
\text { Volume }\left(\mathbf{m}^{\mathbf{3}}\right)\end{array}$ \\
\hline 4 & Red Oak & HW & 38.29 & 19.23 & 0.54 \\
5 & Red Oak & HW & 21.38 & 21.07 & 0.60 \\
7 & Red Oak & HW & 26.71 & 18.99 & 0.54 \\
10 & Sugar Maple & HW & 6.45 & 14.36 & 0.41 \\
11 & Sugar Maple & HW & 22.58 & 17.98 & 0.51 \\
13 & Sugar Maple & HW & 8.78 & 17.96 & 0.51 \\
14 & White Birch & HW & 16.52 & 19.00 & 0.54 \\
15 & Red Oak & HW & 17.96 & 21.50 & 0.61 \\
16 & Aspen & HW & 12.04 & 19.01 & 0.54 \\
17 & Sugar Maple & HW & 14.11 & 19.22 & 0.54 \\
18 & White Birch & HW & 51.21 & 29.94 & 0.85 \\
27 & Red Oak & HW & 33.59 & 22.23 & 0.63
\end{tabular}




\begin{tabular}{|c|c|c|c|c|c|}
\hline 28 & Red Oak & HW & 37.47 & 21.13 & 0.60 \\
\hline 30 & Red Oak & HW & 35.86 & 18.92 & 0.54 \\
\hline 31 & Red Oak & HW & 27.51 & 17.44 & 0.49 \\
\hline 47 & Sugar Maple & HW & 26.36 & 19.55 & 0.55 \\
\hline 49 & Sugar Maple & HW & 30.63 & 20.50 & 0.58 \\
\hline 51 & Sugar Maple & HW & 39.70 & 21.08 & 0.60 \\
\hline 53 & Sugar Maple & HW & 31.31 & 20.71 & 0.59 \\
\hline 55 & Sugar Maple & HW & 29.30 & 17.48 & 0.49 \\
\hline 73 & Sugar Maple & HW & 31.21 & 19.18 & 0.54 \\
\hline 74 & Sugar Maple & HW & 26.26 & 20.23 & 0.57 \\
\hline 75 & Sugar Maple & HW & 27.80 & 20.03 & 0.57 \\
\hline 76 & Sugar Maple & HW & 31.50 & 18.73 & 0.53 \\
\hline 77 & Sugar Maple & HW & 31.45 & 17.87 & 0.51 \\
\hline 82 & Sugar Maple & HW & 27.32 & 18.35 & 0.52 \\
\hline 83 & Red Oak & HW & 35.60 & 20.82 & 0.59 \\
\hline 92 & Yellow Birch & HW & 30.76 & 17.93 & 0.51 \\
\hline 96 & Sugar Maple & HW & 29.83 & 19.51 & 0.55 \\
\hline 100 & Yellow Birch & HW & 39.92 & 15.87 & 0.45 \\
\hline 104 & Sugar Maple & HW & 24.67 & 19.23 & 0.54 \\
\hline 105 & Sugar Maple & HW & 34.43 & 18.35 & 0.52 \\
\hline 107 & Sugar Maple & HW & 42.28 & 23.83 & 0.67 \\
\hline 109 & Sugar Maple & HW & 46.06 & 20.50 & 0.58 \\
\hline 1 & Red Pine & SW & 31.06 & 22.57 & 0.60 \\
\hline 2 & Red Pine & SW & 26.34 & 24.46 & 0.36 \\
\hline 3 & White Pine & SW & 37.97 & 24.14 & 0.94 \\
\hline 6 & Eastern Hemlock & SW & 21.38 & 23.58 & 0.00 \\
\hline 8 & Red Pine & SW & 26.71 & 26.40 & 0.44 \\
\hline 9 & White Pine & SW & 26.76 & 17.96 & 0.22 \\
\hline 12 & Red Pine & SW & 25.60 & 19.00 & 0.27 \\
\hline 19 & Red Pine & SW & 36.02 & 27.65 & 0.92 \\
\hline 20 & White Pine & SW & 21.14 & 17.99 & 0.00 \\
\hline 21 & Red Pine & SW & 37.04 & 30.20 & 1.08 \\
\hline 22 & White Pine & SW & 40.96 & 28.50 & 1.09 \\
\hline 23 & White Pine & SW & 34.90 & 22.15 & 0.67 \\
\hline 24 & Red Pine & SW & 43.14 & 24.49 & 1.26 \\
\hline 25 & Red Pine & SW & 36.21 & 22.54 & 0.81 \\
\hline 26 & Red Pine & SW & 34.08 & 24.48 & 0.72 \\
\hline 29 & Red Pine & SW & 24.41 & 15.93 & 0.17 \\
\hline 32 & Red Pine & SW & 25.65 & 17.04 & 0.27 \\
\hline 106 & Eastern Hemlock & SW & 54.38 & 19.55 & 1.74 \\
\hline
\end{tabular}


Table 32. Estimated 2017 Biomass

\begin{tabular}{|c|c|c|c|c|c|}
\hline Tree ID & Species & Wood & $\begin{array}{c}\text { Height } \\
\text { (m) }\end{array}$ & $\begin{array}{c}\text { DBH } \\
(\mathrm{cm})\end{array}$ & Biomass (kg) \\
\hline 4 & Red Oak & HW & 20.69 & 40.89 & 988.35 \\
\hline 5 & Red Oak & HW & 18.17 & 23.62 & 299.68 \\
\hline 7 & Red Oak & HW & 19.17 & 29.21 & 480.52 \\
\hline 10 & Sugar Maple & HW & 16.99 & 11.43 & 42.29 \\
\hline 11 & Sugar Maple & HW & 20.88 & 25.91 & 383.78 \\
\hline 13 & Sugar Maple & HW & 19.67 & 14.48 & 99.19 \\
\hline 14 & White Birch & HW & 23.97 & 21.08 & 256.90 \\
\hline 15 & Red Oak & HW & 20.87 & 23.37 & 330.93 \\
\hline 16 & Aspen & HW & 20.87 & 15.49 & 78.47 \\
\hline 17 & Sugar Maple & HW & 20.89 & 16.26 & 143.58 \\
\hline 18 & White Birch & HW & 31.36 & 59.18 & 2427.89 \\
\hline 27 & Red Oak & HW & 22.17 & 36.32 & 835.02 \\
\hline 28 & Red Oak & HW & 22.46 & 41.15 & 1076.73 \\
\hline 30 & Red Oak & HW & 19.31 & 37.85 & 799.74 \\
\hline 31 & Red Oak & HW & 16.51 & 29.97 & 441.31 \\
\hline 47 & Sugar Maple & HW & 19.42 & 30.73 & 497.90 \\
\hline 49 & Sugar Maple & HW & 20.87 & 36.07 & 726.24 \\
\hline 51 & Sugar Maple & HW & 22.06 & 44.45 & 1142.99 \\
\hline 53 & Sugar Maple & HW & 20.64 & 35.56 & 701.20 \\
\hline 55 & Sugar Maple & HW & 19.20 & 33.53 & 583.48 \\
\hline 73 & Sugar Maple & HW & 18.69 & 35.31 & 627.37 \\
\hline 74 & Sugar Maple & HW & 19.51 & 30.48 & 493.64 \\
\hline 75 & Sugar Maple & HW & 19.60 & 31.75 & 536.92 \\
\hline 76 & Sugar Maple & HW & 20.42 & 33.78 & 628.81 \\
\hline 77 & Sugar Maple & HW & 20.29 & 33.27 & 605.93 \\
\hline 82 & Sugar Maple & HW & 18.21 & 33.27 & 545.34 \\
\hline 83 & Red Oak & HW & 21.46 & 39.12 & 937.30 \\
\hline 92 & Yellow Birch & HW & 18.51 & 33.53 & 511.70 \\
\hline 96 & Sugar Maple & HW & 21.77 & 34.29 & 685.41 \\
\hline 100 & Yellow Birch & HW & 15.36 & 45.47 & 811.05 \\
\hline 104 & Sugar Maple & HW & 20.66 & 27.94 & 440.94 \\
\hline 105 & Sugar Maple & HW & 18.45 & 36.83 & 671.66 \\
\hline 107 & Sugar Maple & HW & 24.10 & 45.97 & 1325.22 \\
\hline 109 & Sugar Maple & HW & 22.27 & 48.26 & 1351.12 \\
\hline 1 & Red Pine & SW & 20.25 & 33.02 & 440.06 \\
\hline 2 & Red Pine & SW & 25.78 & 29.21 & 429.61 \\
\hline
\end{tabular}




$\begin{array}{cccccc}3 & \text { White Pine } & \text { SW } & 24.18 & 41.15 & 646.31 \\ 6 & \text { Eastern Hemlock } & \text { SW } & 26.45 & 36.83 & 653.49 \\ 8 & \text { Red Pine } & \text { SW } & 27.47 & 29.21 & 454.78 \\ 9 & \text { White Pine } & \text { SW } & 20.29 & 24.38 & 197.32 \\ 12 & \text { Red Pine } & \text { SW } & 19.51 & 29.21 & 333.95 \\ 19 & \text { Red Pine } & \text { SW } & 29.62 & 39.12 & 863.15 \\ 20 & \text { White Pine } & \text { SW } & 18.18 & 26.67 & 217.76 \\ 21 & \text { Red Pine } & \text { SW } & 31.35 & 39.37 & 919.12 \\ 22 & \text { White Pine } & \text { SW } & 28.48 & 49.02 & 1044.04 \\ 23 & \text { White Pine } & \text { SW } & 16.14 & 39.12 & 425.24 \\ 24 & \text { Red Pine } & \text { SW } & 27.27 & 48.26 & 1210.29 \\ 25 & \text { Red Pine } & \text { SW } & 23.82 & 38.35 & 683.51 \\ 26 & \text { Red Pine } & \text { SW } & 24.24 & 36.83 & 640.00 \\ 29 & \text { Red Pine } & \text { SW } & 17.92 & 26.67 & 258.19 \\ 32 & \text { Red Pine } & \text { SW } & 19.14 & 31.24 & 374.48 \\ 106 & \text { Eastern Hemlock } & \text { SW } & 22.31 & 58.93 & 1463.99\end{array}$

Table 33. Estimated 2011 Biomass

\begin{tabular}{cccccc}
\hline Tree ID & Species & Wood & $\begin{array}{c}\text { DBH } \\
(\mathbf{c m})\end{array}$ & $\begin{array}{c}\text { Height } \\
(\mathbf{m})\end{array}$ & Biomass(kg) \\
\hline 4 & Red Oak & HW & 38.29 & 19.23 & 816.53 \\
5 & Red Oak & HW & 21.38 & 21.07 & 274.92 \\
7 & Red Oak & HW & 26.71 & 18.99 & 398.49 \\
10 & Sugar Maple & HW & 6.45 & 14.36 & 10.52 \\
11 & Sugar Maple & HW & 22.58 & 17.98 & 254.23 \\
13 & Sugar Maple & HW & 8.78 & 17.96 & 22.22 \\
14 & White Birch & HW & 16.52 & 19.00 & 124.69 \\
15 & Red Oak & HW & 17.96 & 21.50 & 192.18 \\
16 & Aspen & HW & 12.04 & 19.01 & 28.79 \\
17 & Sugar Maple & HW & 14.11 & 19.22 & 91.22 \\
18 & White Birch & HW & 51.21 & 29.94 & 1764.76 \\
27 & Red Oak & HW & 33.59 & 22.23 & 718.60 \\
28 & Red Oak & HW & 37.47 & 21.13 & 849.68 \\
30 & Red Oak & HW & 35.86 & 18.92 & 706.96 \\
31 & Red Oak & HW & 27.51 & 17.44 & 391.03 \\
47 & Sugar Maple & HW & 26.36 & 19.55 & 372.49 \\
49 & Sugar Maple & HW & 30.63 & 20.50 & 522.71
\end{tabular}




$\begin{array}{rccccc}51 & \text { Sugar Maple } & \text { HW } & 39.70 & 21.08 & 883.20 \\ 53 & \text { Sugar Maple } & \text { HW } & 31.31 & 20.71 & 550.30 \\ 55 & \text { Sugar Maple } & \text { HW } & 29.30 & 17.48 & 410.26 \\ 73 & \text { Sugar Maple } & \text { HW } & 31.21 & 19.18 & 508.96 \\ 74 & \text { Sugar Maple } & \text { HW } & 26.26 & 20.23 & 382.82 \\ 75 & \text { Sugar Maple } & \text { HW } & 27.80 & 20.03 & 423.86 \\ 76 & \text { Sugar Maple } & \text { HW } & 31.50 & 18.73 & 505.79 \\ 77 & \text { Sugar Maple } & \text { HW } & 31.45 & 17.87 & 481.49 \\ 82 & \text { Sugar Maple } & \text { HW } & 27.32 & 18.35 & 375.13 \\ 83 & \text { Red Oak } & \text { HW } & 35.60 & 20.82 & 759.51 \\ 92 & \text { Yellow Birch } & \text { HW } & 30.76 & 17.93 & 423.03 \\ 96 & \text { Sugar Maple } & \text { HW } & 29.83 & 19.51 & 473.16 \\ 100 & \text { Yellow Birch } & \text { HW } & 39.92 & 15.87 & 645.89 \\ 104 & \text { Sugar Maple } & \text { HW } & 24.67 & 19.23 & 321.09 \\ 105 & \text { Sugar Maple } & \text { HW } & 34.43 & 18.35 & 588.53 \\ 107 & \text { Sugar Maple } & \text { HW } & 42.28 & 23.83 & 1116.46 \\ 109 & \text { Sugar Maple } & \text { HW } & 46.06 & 20.50 & 1143.33 \\ 1 & \text { Red Pine } & \text { SW } & 31.06 & 22.57 & 429.79 \\ 2 & \text { Red Pine } & \text { SW } & 26.34 & 24.46 & 332.70 \\ 3 & \text { White Pine } & \text { SW } & 37.97 & 24.14 & 550.06 \\ 6 & \text { Eastern Hemlock } & \text { SW } & 21.38 & 23.58 & 183.65 \\ 8 & \text { Red Pine } & \text { SW } & 26.71 & 26.40 & 366.15 \\ 9 & \text { White Pine } & \text { SW } & 26.76 & 17.96 & 216.17 \\ 12 & \text { Red Pine } & \text { SW } & 25.60 & 19.00 & 250.42 \\ 19 & \text { Red Pine } & \text { SW } & 36.02 & 27.65 & 690.46 \\ 20 & \text { White Pine } & \text { SW } & 21.14 & 17.99 & 133.48 \\ 21 & \text { Red Pine } & \text { SW } & 37.04 & 30.20 & 789.01 \\ 22 & \text { White Pine } & \text { SW } & 40.96 & 28.50 & 732.52 \\ 23 & \text { White Pine } & \text { SW } & 34.90 & 22.15 & 435.09 \\ 24 & \text { Red Pine } & \text { SW } & 43.14 & 24.49 & 882.71 \\ 25 & \text { Red Pine } & \text { SW } & 36.21 & 22.54 & 580.77 \\ 26 & \text { Red Pine } & \text { SW } & 34.08 & 24.48 & 554.19 \\ 29 & \text { Red Pine } & \text { SW } & 24.41 & 15.93 & 193.52 \\ 32 & \text { Red Pine } & \text { SW } & 25.65 & 17.04 & 228.39 \\ 106 & \text { Eastern Hemlock } & \text { SW } & 54.38 & 19.55 & 1107.67\end{array}$




\section{Estimated Volume and Biomass by Using Predicted DBH Derived from LiDAR Variables}

\subsection{Testing 2017 Equation}

Table 34. Estimated 2017 Volume; 2017 Equation Tested on 2017 Dataset

\begin{tabular}{|c|c|c|c|c|c|}
\hline Tree ID & Species & Wood & $\begin{array}{l}\text { DBH } \\
(\mathbf{c m})\end{array}$ & $\begin{array}{c}\text { Height } \\
\text { (m) }\end{array}$ & $\begin{array}{l}\text { Merchantable } \\
\text { Volume }\left(\mathbf{m}^{3}\right)\end{array}$ \\
\hline 4 & Red Oak & HW & 31.01 & 20.69 & 0.29 \\
\hline 5 & Red Oak & HW & 20.93 & 18.17 & 0.00 \\
\hline 7 & Red Oak & HW & 26.68 & 19.17 & 0.00 \\
\hline 10 & Sugar Maple & HW & 12.34 & 16.99 & 0.00 \\
\hline 11 & Sugar Maple & HW & 29.33 & 20.88 & 0.00 \\
\hline 13 & Sugar Maple & HW & 25.93 & 19.67 & 0.00 \\
\hline 14 & White Birch & HW & 28.99 & 23.97 & 0.00 \\
\hline 15 & Red Oak & HW & 29.32 & 20.87 & 0.00 \\
\hline 16 & Aspen & HW & 27.75 & 20.87 & 0.00 \\
\hline 17 & Sugar Maple & HW & 27.24 & 20.89 & 0.00 \\
\hline 18 & White Birch & HW & 45.91 & 31.36 & 1.25 \\
\hline 27 & Red Oak & HW & 31.81 & 22.17 & 0.47 \\
\hline 28 & Red Oak & HW & 30.39 & 22.46 & 0.00 \\
\hline 30 & Red Oak & HW & 32.44 & 19.31 & 0.28 \\
\hline 31 & Red Oak & HW & 26.60 & 16.51 & 0.00 \\
\hline 47 & Sugar Maple & HW & 38.76 & 19.42 & 0.30 \\
\hline 49 & Sugar Maple & HW & 42.00 & 20.87 & 0.31 \\
\hline 51 & Sugar Maple & HW & 45.92 & 22.06 & 0.53 \\
\hline 53 & Sugar Maple & HW & 32.57 & 20.64 & 0.30 \\
\hline 55 & Sugar Maple & HW & 34.46 & 19.20 & 0.15 \\
\hline 73 & Sugar Maple & HW & 34.25 & 18.69 & 0.00 \\
\hline 74 & Sugar Maple & HW & 36.76 & 19.51 & 0.59 \\
\hline 75 & Sugar Maple & HW & 34.28 & 19.60 & 0.59 \\
\hline 76 & Sugar Maple & HW & 38.61 & 20.42 & 0.00 \\
\hline 77 & Sugar Maple & HW & 34.92 & 20.29 & 0.30 \\
\hline 82 & Sugar Maple & HW & 38.15 & 18.21 & 0.69 \\
\hline 83 & Red Oak & HW & 31.88 & 21.46 & 0.00 \\
\hline 92 & Yellow Birch & HW & 29.84 & 18.51 & 0.00 \\
\hline 96 & Sugar Maple & HW & 34.97 & 21.77 & 0.00 \\
\hline
\end{tabular}




$\begin{array}{cccccc}100 & \text { Yellow Birch } & \text { HW } & 35.85 & 15.36 & 0.31 \\ 104 & \text { Sugar Maple } & \text { HW } & 37.30 & 20.66 & 0.56 \\ 105 & \text { Sugar Maple } & \text { HW } & 36.39 & 18.45 & 0.37 \\ 107 & \text { Sugar Maple } & \text { HW } & 41.88 & 24.10 & 0.77 \\ 109 & \text { Sugar Maple } & \text { HW } & 49.63 & 22.27 & 0.61 \\ 1 & \text { Red Pine } & \text { SW } & 26.86 & 20.25 & 0.39 \\ 2 & \text { Red Pine } & \text { SW } & 35.27 & 25.78 & 1.02 \\ 3 & \text { White Pine } & \text { SW } & 36.56 & 24.18 & 0.61 \\ 6 & \text { Eastern Hemlock } & \text { SW } & 36.37 & 26.45 & 0.63 \\ 8 & \text { Red Pine } & \text { SW } & 39.98 & 27.47 & 0.82 \\ 9 & \text { White Pine } & \text { SW } & 20.86 & 20.29 & 0.00 \\ 12 & \text { Red Pine } & \text { SW } & 23.28 & 19.51 & 0.27 \\ 19 & \text { Red Pine } & \text { SW } & 42.70 & 29.62 & 1.16 \\ 20 & \text { White Pine } & \text { SW } & 28.50 & 18.18 & 0.00 \\ 21 & \text { Red Pine } & \text { SW } & 46.31 & 31.35 & 1.53 \\ 22 & \text { White Pine } & \text { SW } & 48.62 & 28.48 & 1.21 \\ 23 & \text { White Pine } & \text { SW } & 44.58 & 16.14 & 0.63 \\ 24 & \text { Red Pine } & \text { SW } & 31.91 & 27.27 & 0.56 \\ 25 & \text { Red Pine } & \text { SW } & 31.91 & 23.82 & 0.70 \\ 26 & \text { Red Pine } & \text { SW } & 28.02 & 24.24 & 0.00 \\ 29 & \text { Red Pine } & \text { SW } & 31.72 & 17.92 & 0.15 \\ 32 & \text { Red Pine } & \text { SW } & 44.77 & 19.14 & 1.04 \\ 106 & \text { Eastern Hemlock } & \text { SW } & 33.09 & 22.31 & 0.55\end{array}$

Table 35. Estimated 2011 Volume; 2017 Equation Tested on 2011 Dataset

\begin{tabular}{cccccc}
\hline Tree ID & Species & Wood & $\begin{array}{c}\text { DBH } \\
(\mathbf{c m})\end{array}$ & $\begin{array}{c}\text { Height } \\
(\mathbf{m})\end{array}$ & $\begin{array}{c}\text { Merchantable } \\
\text { Volume }\left(\mathbf{m}^{\mathbf{3}}\right)\end{array}$ \\
\hline 4 & Red Oak & HW & 30.80 & 19.23 & 0.29 \\
5 & Red Oak & HW & 26.60 & 21.07 & 0.00 \\
7 & Red Oak & HW & 22.63 & 18.99 & 0.00 \\
10 & Sugar Maple & HW & 15.36 & 14.36 & 0.00 \\
11 & Sugar Maple & HW & 23.74 & 17.98 & 0.00 \\
13 & Sugar Maple & HW & 20.53 & 17.96 & 0.00 \\
14 & White Birch & HW & 23.90 & 19.00 & 0.00 \\
15 & Red Oak & HW & 25.55 & 21.50 & 0.00
\end{tabular}




\begin{tabular}{|c|c|c|c|c|c|}
\hline 16 & Aspen & HW & 21.45 & 19.01 & 0.00 \\
\hline 17 & Sugar Maple & HW & 19.67 & 19.22 & 0.00 \\
\hline 18 & White Birch & HW & 42.16 & 29.94 & 1.25 \\
\hline 27 & Red Oak & HW & 33.22 & 22.23 & 0.47 \\
\hline 28 & Red Oak & HW & 23.45 & 21.13 & 0.00 \\
\hline 30 & Red Oak & HW & 30.11 & 18.92 & 0.28 \\
\hline 31 & Red Oak & HW & 26.02 & 17.44 & 0.00 \\
\hline 47 & Sugar Maple & HW & 30.82 & 19.55 & 0.30 \\
\hline 49 & Sugar Maple & HW & 31.38 & 20.50 & 0.31 \\
\hline 51 & Sugar Maple & HW & 34.70 & 21.08 & 0.53 \\
\hline 53 & Sugar Maple & HW & 30.90 & 20.71 & 0.30 \\
\hline 55 & Sugar Maple & HW & 28.22 & 17.48 & 0.15 \\
\hline 73 & Sugar Maple & HW & 26.85 & 19.18 & 0.00 \\
\hline 74 & Sugar Maple & HW & 36.71 & 20.23 & 0.59 \\
\hline 75 & Sugar Maple & HW & 36.86 & 20.03 & 0.59 \\
\hline 76 & Sugar Maple & HW & 25.93 & 18.73 & 0.00 \\
\hline 77 & Sugar Maple & HW & 30.64 & 17.87 & 0.30 \\
\hline 82 & Sugar Maple & HW & 40.73 & 18.35 & 0.69 \\
\hline 83 & Red Oak & HW & 24.51 & 20.82 & 0.00 \\
\hline 92 & Yellow Birch & HW & 24.33 & 17.93 & 0.00 \\
\hline 96 & Sugar Maple & HW & 24.86 & 19.51 & 0.00 \\
\hline 100 & Yellow Birch & HW & 31.84 & 15.87 & 0.31 \\
\hline 104 & Sugar Maple & HW & 35.82 & 19.23 & 0.56 \\
\hline 105 & Sugar Maple & HW & 34.19 & 18.35 & 0.37 \\
\hline 107 & Sugar Maple & HW & 38.56 & 23.83 & 0.77 \\
\hline 109 & Sugar Maple & HW & 37.47 & 20.50 & 0.61 \\
\hline 1 & Red Pine & SW & 27.34 & 22.57 & 0.39 \\
\hline 2 & Red Pine & SW & 38.03 & 24.46 & 1.02 \\
\hline 3 & White Pine & SW & 33.30 & 24.14 & 0.61 \\
\hline 6 & Eastern Hemlock & SW & 32.61 & 23.58 & 0.63 \\
\hline 8 & Red Pine & SW & 33.97 & 26.40 & 0.82 \\
\hline 9 & White Pine & SW & 21.22 & 17.96 & 0.00 \\
\hline 12 & Red Pine & SW & 25.41 & 19.00 & 0.27 \\
\hline 19 & Red Pine & SW & 39.14 & 27.65 & 1.16 \\
\hline 20 & White Pine & SW & 21.47 & 17.99 & 0.00 \\
\hline 21 & Red Pine & SW & 42.99 & 30.20 & 1.53 \\
\hline 22 & White Pine & SW & 43.02 & 28.50 & 1.21 \\
\hline 23 & White Pine & SW & 40.78 & 22.15 & 0.94 \\
\hline
\end{tabular}




$\begin{array}{llllll}24 & \text { Red Pine } & \text { SW } & 30.09 & 24.49 & 0.56 \\ 25 & \text { Red Pine } & \text { SW } & 33.74 & 22.54 & 0.70 \\ 26 & \text { Red Pine } & \text { SW } & 20.24 & 24.48 & 0.00 \\ 29 & \text { Red Pine } & \text { SW } & 22.95 & 15.93 & 0.15 \\ 32 & \text { Red Pine } & \text { SW } & 42.02 & 17.04 & 0.88 \\ 106 & \text { Eastern Hemlock } & \text { SW } & 33.09 & 19.55 & 0.55\end{array}$

Table 36. Estimated 2017 Biomass; 2017 Equation Tested on 2017 Dataset

\begin{tabular}{|c|c|c|c|c|c|}
\hline Tree ID & Species & Wood & $\begin{array}{c}\text { Height } \\
\text { (m) }\end{array}$ & $\begin{array}{c}\text { DBH } \\
(\mathrm{cm})\end{array}$ & Biomass (kg) \\
\hline 4 & Red Oak & HW & 20.69 & 27.70 & 460.58 \\
\hline 5 & Red Oak & HW & 18.17 & 35.76 & 678.74 \\
\hline 7 & Red Oak & HW & 19.17 & 33.58 & 629.79 \\
\hline 10 & Sugar Maple & HW & 16.99 & 28.35 & 375.25 \\
\hline 11 & Sugar Maple & HW & 20.88 & 28.96 & 475.44 \\
\hline 13 & Sugar Maple & HW & 19.67 & 36.27 & 694.57 \\
\hline 14 & White Birch & HW & 23.97 & 23.30 & 315.41 \\
\hline 15 & Red Oak & HW & 20.87 & 33.75 & 684.18 \\
\hline 16 & Aspen & HW & 20.87 & 22.26 & 183.85 \\
\hline 17 & Sugar Maple & HW & 20.89 & 17.99 & 180.68 \\
\hline 18 & White Birch & HW & 31.36 & 28.11 & 574.98 \\
\hline 27 & Red Oak & HW & 22.17 & 30.48 & 591.27 \\
\hline 28 & Red Oak & HW & 22.46 & 24.13 & 375.77 \\
\hline 30 & Red Oak & HW & 19.31 & 29.17 & 480.64 \\
\hline 31 & Red Oak & HW & 16.51 & 25.45 & 319.98 \\
\hline 47 & Sugar Maple & HW & 19.42 & 25.62 & 351.68 \\
\hline 49 & Sugar Maple & HW & 20.87 & 22.02 & 276.46 \\
\hline 51 & Sugar Maple & HW & 22.06 & 42.19 & 1034.42 \\
\hline 53 & Sugar Maple & HW & 20.64 & 39.34 & 850.98 \\
\hline 55 & Sugar Maple & HW & 19.20 & 23.17 & 283.84 \\
\hline 73 & Sugar Maple & HW & 18.69 & 45.48 & 1021.29 \\
\hline 74 & Sugar Maple & HW & 19.51 & 41.39 & 888.26 \\
\hline 75 & Sugar Maple & HW & 19.60 & 29.00 & 450.58 \\
\hline 76 & Sugar Maple & HW & 20.42 & 38.95 & 825.93 \\
\hline 77 & Sugar Maple & HW & 20.29 & 30.90 & 526.89 \\
\hline 82 & Sugar Maple & HW & 18.21 & 31.03 & 477.57 \\
\hline 83 & Red Oak & HW & 21.46 & 32.19 & 641.56 \\
\hline 92 & Yellow Birch & HW & 18.51 & 26.73 & 328.36 \\
\hline
\end{tabular}




$\begin{array}{cccccc}96 & \text { Sugar Maple } & \text { HW } & 21.77 & 20.45 & 249.28 \\ 100 & \text { Yellow Birch } & \text { HW } & 15.36 & 28.25 & 322.86 \\ 104 & \text { Sugar Maple } & \text { HW } & 20.66 & 23.68 & 318.56 \\ 105 & \text { Sugar Maple } & \text { HW } & 18.45 & 24.94 & 315.33 \\ 107 & \text { Sugar Maple } & \text { HW } & 24.10 & 33.18 & 708.00 \\ & & & & & \\ 109 & \text { Sugar Maple } & \text { HW } & 22.27 & 33.19 & 659.50 \\ 1 & \text { Red Pine } & \text { SW } & 20.25 & 37.19 & 555.19 \\ 2 & \text { Red Pine } & \text { SW } & 25.78 & 35.67 & 635.98 \\ 3 & \text { White Pine } & \text { SW } & 24.18 & 28.39 & 307.69 \\ 6 & \text { Eastern Hemlock } & \text { SW } & 26.45 & 27.93 & 365.60 \\ 8 & \text { Red Pine } & \text { SW } & 27.47 & 34.74 & 638.46 \\ 9 & \text { White Pine } & \text { SW } & 20.29 & 32.44 & 351.20 \\ 12 & \text { Red Pine } & \text { SW } & 19.51 & 30.50 & 363.26 \\ 19 & \text { Red Pine } & \text { SW } & 29.62 & 25.56 & 372.28 \\ 20 & \text { White Pine } & \text { SW } & 18.18 & 26.39 & 213.27 \\ 21 & \text { Red Pine } & \text { SW } & 31.35 & 25.17 & 379.44 \\ 22 & \text { White Pine } & \text { SW } & 28.48 & 25.01 & 269.86 \\ 23 & \text { White Pine } & \text { SW } & 16.14 & 31.00 & 267.87 \\ 24 & \text { Red Pine } & \text { SW } & 27.27 & 27.68 & 405.74 \\ 25 & \text { Red Pine } & \text { SW } & 23.82 & 35.00 & 570.08 \\ 26 & \text { Red Pine } & \text { SW } & 24.24 & 30.44 & 440.31 \\ 29 & \text { Red Pine } & \text { SW } & 17.92 & 33.16 & 396.64 \\ 32 & \text { Red Pine } & \text { SW } & 19.14 & 40.51 & 624.11 \\ 106 & \text { Eastern Hemlock } & \text { SW } & 22.31 & 29.97 & 367.47\end{array}$

Table 37. Estimated 2011 Biomass; 2017 Equation Tested on 2011 Dataset

\begin{tabular}{cccccc}
\hline Tree ID & Species & Wood & $\begin{array}{c}\text { Height } \\
(\mathbf{m})\end{array}$ & $\begin{array}{c}\text { DBH } \\
(\mathbf{c m})\end{array}$ & Biomass (kg) \\
\hline 4 & Red Oak & HW & 19.23 & 30.80 & 532.07 \\
5 & Red Oak & HW & 21.07 & 26.60 & 431.35 \\
7 & Red Oak & HW & 18.99 & 22.63 & 285.56 \\
10 & Sugar Maple & HW & 14.36 & 15.36 & 83.04 \\
11 & Sugar Maple & HW & 17.98 & 23.74 & 279.88 \\
13 & Sugar Maple & HW & 17.96 & 20.53 & 209.30 \\
14 & White Birch & HW & 19.00 & 23.90 & 272.09 \\
15 & Red Oak & HW & 21.50 & 25.55 & 404.47
\end{tabular}




\begin{tabular}{|c|c|c|c|c|c|}
\hline 16 & Aspen & HW & 19.01 & 21.45 & 157.89 \\
\hline 17 & Sugar Maple & HW & 19.22 & 19.67 & 203.41 \\
\hline 18 & White Birch & HW & 29.94 & 42.16 & 1211.20 \\
\hline 27 & Red Oak & HW & 22.23 & 33.22 & 701.41 \\
\hline 28 & Red Oak & HW & 21.13 & 23.45 & 336.26 \\
\hline 30 & Red Oak & HW & 18.92 & 30.11 & 502.09 \\
\hline 31 & Red Oak & HW & 17.44 & 26.02 & 351.35 \\
\hline 47 & Sugar Maple & HW & 19.55 & 30.82 & 505.04 \\
\hline 49 & Sugar Maple & HW & 20.50 & 31.38 & 547.65 \\
\hline 51 & Sugar Maple & HW & 21.08 & 34.70 & 681.88 \\
\hline 53 & Sugar Maple & HW & 20.71 & 30.90 & 536.69 \\
\hline 55 & Sugar Maple & HW & 17.48 & 28.22 & 380.52 \\
\hline 73 & Sugar Maple & HW & 19.18 & 26.85 & 378.79 \\
\hline 74 & Sugar Maple & HW & 20.23 & 36.71 & 729.32 \\
\hline 75 & Sugar Maple & HW & 20.03 & 36.86 & 728.94 \\
\hline 76 & Sugar Maple & HW & 18.73 & 25.93 & 345.85 \\
\hline 77 & Sugar Maple & HW & 17.87 & 30.64 & 456.43 \\
\hline 82 & Sugar Maple & HW & 18.35 & 40.73 & 812.05 \\
\hline 83 & Red Oak & HW & 20.82 & 24.51 & 363.62 \\
\hline 92 & Yellow Birch & HW & 17.93 & 24.33 & 266.39 \\
\hline 96 & Sugar Maple & HW & 19.51 & 24.86 & 330.78 \\
\hline 100 & Yellow Birch & HW & 15.87 & 31.84 & 418.47 \\
\hline 104 & Sugar Maple & HW & 19.23 & 35.82 & 664.53 \\
\hline 105 & Sugar Maple & HW & 18.35 & 34.19 & 579.45 \\
\hline 107 & Sugar Maple & HW & 23.83 & 38.56 & 936.28 \\
\hline 109 & Sugar Maple & HW & 20.50 & 37.47 & 767.96 \\
\hline 1 & Red Pine & SW & 22.57 & 27.34 & 333.60 \\
\hline 2 & Red Pine & SW & 24.46 & 38.03 & 687.08 \\
\hline 3 & White Pine & SW & 24.14 & 33.30 & 423.91 \\
\hline 6 & Eastern Hemlock & SW & 23.58 & 32.61 & 458.50 \\
\hline 8 & Red Pine & SW & 26.40 & 33.97 & 589.23 \\
\hline 9 & White Pine & SW & 17.96 & 21.22 & 133.45 \\
\hline 12 & Red Pine & SW & 19.00 & 25.41 & 247.16 \\
\hline 19 & Red Pine & SW & 27.65 & 39.14 & 811.87 \\
\hline 20 & White Pine & SW & 17.99 & 21.47 & 138.02 \\
\hline 21 & Red Pine & SW & 30.20 & 42.99 & 1057.42 \\
\hline 22 & White Pine & SW & 28.50 & 43.02 & 806.43 \\
\hline 23 & White Pine & SW & 22.15 & 40.78 & 592.17 \\
\hline 24 & Red Pine & SW & 24.49 & 30.09 & 433.90 \\
\hline
\end{tabular}




$\begin{array}{cccccc}25 & \text { Red Pine } & \text { SW } & 22.54 & 33.74 & 504.52 \\ 26 & \text { Red Pine } & \text { SW } & 24.48 & 20.24 & 192.87 \\ 29 & \text { Red Pine } & \text { SW } & 15.93 & 22.95 & 170.50 \\ 32 & \text { Red Pine } & \text { SW } & 17.04 & 42.02 & 603.38 \\ 106 & \text { Eastern Hemlock } & \text { SW } & 19.55 & 29.97 & 326.83\end{array}$

\subsection{Testing 2011 Equation}

Table 38. Estimated 2011 Volume; 2011 Equation Tested on 2011 Dataset

\begin{tabular}{|c|c|c|c|c|c|}
\hline Tree ID & Species & Wood & $\begin{array}{l}\text { DBH } \\
(\mathrm{cm})\end{array}$ & $\begin{array}{c}\text { Height } \\
\text { (m) }\end{array}$ & $\begin{array}{l}\text { Merchantable } \\
\text { Volume }\left(\mathbf{m}^{3}\right)\end{array}$ \\
\hline 4 & Red Oak & HW & 31.16 & 19.23 & 0.30 \\
\hline 5 & Red Oak & HW & 26.16 & 21.07 & 0.00 \\
\hline 7 & Red Oak & HW & 21.68 & 18.99 & 0.00 \\
\hline 10 & Sugar Maple & HW & 18.91 & 14.36 & 0.00 \\
\hline 11 & Sugar Maple & HW & 25.58 & 17.98 & 0.00 \\
\hline 13 & Sugar Maple & HW & 20.27 & 17.96 & 0.00 \\
\hline 14 & White Birch & HW & 25.17 & 19.00 & 0.00 \\
\hline 15 & Red Oak & HW & 23.30 & 21.50 & 0.00 \\
\hline 16 & Aspen & HW & 22.48 & 19.01 & 0.00 \\
\hline 17 & Sugar Maple & HW & 19.96 & 19.22 & 0.00 \\
\hline 18 & White Birch & HW & 41.33 & 29.94 & 1.21 \\
\hline 27 & Red Oak & HW & 33.03 & 22.23 & 0.47 \\
\hline 28 & Red Oak & HW & 23.19 & 21.13 & 0.00 \\
\hline 30 & Red Oak & HW & 30.26 & 18.92 & 0.28 \\
\hline 31 & Red Oak & HW & 25.71 & 17.44 & 0.00 \\
\hline 47 & Sugar Maple & HW & 31.90 & 19.55 & 0.32 \\
\hline 49 & Sugar Maple & HW & 31.95 & 20.50 & 0.32 \\
\hline 51 & Sugar Maple & HW & 35.83 & 21.08 & 0.56 \\
\hline 53 & Sugar Maple & HW & 31.38 & 20.71 & 0.31 \\
\hline 55 & Sugar Maple & HW & 28.03 & 17.48 & 0.14 \\
\hline 73 & Sugar Maple & HW & 28.21 & 19.18 & 0.15 \\
\hline 74 & Sugar Maple & HW & 36.71 & 20.23 & 0.59 \\
\hline 75 & Sugar Maple & HW & 36.34 & 20.03 & 0.58 \\
\hline 76 & Sugar Maple & HW & 28.48 & 18.73 & 0.15 \\
\hline 77 & Sugar Maple & HW & 29.37 & 17.87 & 0.16 \\
\hline 82 & Sugar Maple & HW & 38.84 & 18.35 & 0.62 \\
\hline
\end{tabular}




$\begin{array}{cccccc}83 & \text { Red Oak } & \text { HW } & 22.38 & 20.82 & 0.00 \\ 92 & \text { Yellow Birch } & \text { HW } & 24.58 & 17.93 & 0.00 \\ 96 & \text { Sugar Maple } & \text { HW } & 27.38 & 19.51 & 0.00 \\ 100 & \text { Yellow Birch } & \text { HW } & 33.51 & 15.87 & 0.35 \\ 104 & \text { Sugar Maple } & \text { HW } & 37.25 & 19.23 & 0.61 \\ 105 & \text { Sugar Maple } & \text { HW } & 34.40 & 18.35 & 0.38 \\ 107 & \text { Sugar Maple } & \text { HW } & 39.33 & 23.83 & 0.80 \\ 109 & \text { Sugar Maple } & \text { HW } & 35.80 & 20.50 & 0.56 \\ 1 & \text { Red Pine } & \text { SW } & 26.05 & 22.57 & 0.35 \\ 2 & \text { Red Pine } & \text { SW } & 36.65 & 24.46 & 0.95 \\ 3 & \text { White Pine } & \text { SW } & 33.17 & 24.14 & 0.60 \\ 6 & \text { Eastern Hemlock } & \text { SW } & 32.76 & 23.58 & 0.64 \\ 8 & \text { Red Pine } & \text { SW } & 32.91 & 26.40 & 0.77 \\ 9 & \text { White Pine } & \text { SW } & 20.83 & 17.96 & 0.00 \\ 12 & \text { Red Pine } & \text { SW } & 27.79 & 19.00 & 0.32 \\ 19 & \text { Red Pine } & \text { SW } & 38.45 & 27.65 & 1.12 \\ 20 & \text { White Pine } & \text { SW } & 22.90 & 17.99 & 0.09 \\ 21 & \text { Red Pine } & \text { SW } & 43.51 & 30.20 & 1.57 \\ 22 & \text { White Pine } & \text { SW } & 41.88 & 28.50 & 1.14 \\ 23 & \text { White Pine } & \text { SW } & 40.16 & 22.15 & 0.91 \\ 24 & \text { Red Pine } & \text { SW } & 29.66 & 24.49 & 0.54 \\ 25 & \text { Red Pine } & \text { SW } & 31.99 & 22.54 & 0.63 \\ 26 & \text { Red Pine } & \text { SW } & 21.06 & 24.48 & 0.00 \\ 29 & \text { Red Pine } & \text { SW } & 25.08 & 15.93 & 0.18 \\ 32 & \text { Red Pine } & \text { SW } & 41.40 & 17.04 & 0.85 \\ 106 & \text { Eastern Hemlock } & \text { SW } & 33.09 & 19.55 & 0.55\end{array}$

Table 39. Estimated 2017 Volume; 2011 Equation Tested on 2017 Dataset

\begin{tabular}{cccccc}
\hline Tree ID & Species & Wood & $\begin{array}{c}\text { DBH } \\
\mathbf{( c m )}\end{array}$ & $\begin{array}{c}\text { Height } \\
\mathbf{( m )}\end{array}$ & $\begin{array}{c}\text { Merchantable } \\
\text { Volume }\left(\mathbf{m}^{\mathbf{3}}\right)\end{array}$ \\
\hline 4 & Red Oak & HW & 31.16 & 20.69 & 0.30 \\
5 & Red Oak & HW & 21.98 & 18.17 & 0.00 \\
7 & Red Oak & HW & 28.34 & 19.17 & 0.14 \\
10 & Sugar Maple & HW & 11.75 & 16.99 & 0.00 \\
11 & Sugar Maple & HW & 29.28 & 20.88 & 0.27 \\
13 & Sugar Maple & HW & 26.93 & 19.67 & 0.00
\end{tabular}




\begin{tabular}{|c|c|c|c|c|c|}
\hline 14 & White Birch & HW & 31.99 & 23.97 & 0.45 \\
\hline 15 & Red Oak & HW & 27.92 & 20.87 & 0.00 \\
\hline 16 & Aspen & HW & 27.74 & 20.87 & 0.22 \\
\hline 17 & Sugar Maple & HW & 26.56 & 20.89 & 0.00 \\
\hline 18 & White Birch & HW & 44.12 & 31.36 & 1.53 \\
\hline 27 & Red Oak & HW & 32.66 & 22.17 & 0.46 \\
\hline 28 & Red Oak & HW & 30.15 & 22.46 & 0.28 \\
\hline 30 & Red Oak & HW & 33.41 & 19.31 & 0.35 \\
\hline 31 & Red Oak & HW & 26.75 & 16.51 & 0.00 \\
\hline 47 & Sugar Maple & HW & 38.12 & 19.42 & 0.60 \\
\hline 49 & Sugar Maple & HW & 41.61 & 20.87 & 0.89 \\
\hline 51 & Sugar Maple & HW & 45.26 & 22.06 & 1.06 \\
\hline 53 & Sugar Maple & HW & 34.07 & 20.64 & 0.51 \\
\hline 55 & Sugar Maple & HW & 33.35 & 19.20 & 0.35 \\
\hline 73 & Sugar Maple & HW & 32.81 & 18.69 & 0.34 \\
\hline 74 & Sugar Maple & HW & 35.63 & 19.51 & 0.56 \\
\hline 75 & Sugar Maple & HW & 32.53 & 19.60 & 0.33 \\
\hline 76 & Sugar Maple & HW & 37.54 & 20.42 & 0.61 \\
\hline 77 & Sugar Maple & HW & 32.52 & 20.29 & 0.33 \\
\hline 82 & Sugar Maple & HW & 37.91 & 18.21 & 0.63 \\
\hline 83 & Red Oak & HW & 28.96 & 21.46 & 0.26 \\
\hline 92 & Yellow Birch & HW & 28.31 & 18.51 & 0.14 \\
\hline 96 & Sugar Maple & HW & 32.09 & 21.77 & 0.45 \\
\hline 100 & Yellow Birch & HW & 36.06 & 15.36 & 0.41 \\
\hline 104 & Sugar Maple & HW & 36.00 & 20.66 & 0.57 \\
\hline 105 & Sugar Maple & HW & 35.64 & 18.45 & 0.56 \\
\hline 107 & Sugar Maple & HW & 41.76 & 24.10 & 0.90 \\
\hline 109 & Sugar Maple & HW & 50.69 & 22.27 & 1.58 \\
\hline 1 & Red Pine & SW & 26.90 & 20.25 & 0.30 \\
\hline 2 & Red Pine & SW & 35.01 & 25.78 & 0.87 \\
\hline 3 & White Pine & SW & 35.65 & 24.18 & 0.83 \\
\hline 6 & Eastern Hemlock & SW & 37.51 & 26.45 & 0.96 \\
\hline 8 & Red Pine & SW & 41.50 & 27.47 & 1.31 \\
\hline 9 & White Pine & SW & 20.79 & 20.29 & 0.00 \\
\hline 12 & Red Pine & SW & 25.18 & 19.51 & 0.26 \\
\hline 19 & Red Pine & SW & 43.54 & 29.62 & 1.57 \\
\hline 20 & White Pine & SW & 32.25 & 18.18 & 0.45 \\
\hline 21 & Red Pine & SW & 46.08 & 31.35 & \\
\hline
\end{tabular}




$\begin{array}{llllll}22 & \text { White Pine } & \text { SW } & 47.95 & 28.48 & 1.67 \\ 23 & \text { White Pine } & \text { SW } & 45.47 & 16.14 & 0.99 \\ 24 & \text { Red Pine } & \text { SW } & 32.73 & 27.27 & 0.76 \\ 25 & \text { Red Pine } & \text { SW } & 32.53 & 23.82 & 0.65 \\ 26 & \text { Red Pine } & \text { SW } & 29.59 & 24.24 & 0.54 \\ 29 & \text { Red Pine } & \text { SW } & 33.40 & 17.92 & 0.58 \\ 32 & \text { Red Pine } & \text { SW } & 45.62 & 19.14 & 1.23 \\ 106 & \text { Eastern Hemlock } & \text { SW } & 33.09 & 22.31 & 0.55\end{array}$

Table 40. Estimated 2011 Biomass; 2011 Equation Tested on 2011 Dataset

\begin{tabular}{|c|c|c|c|c|c|}
\hline Tree ID & Species & Wood & $\begin{array}{c}\text { Height } \\
\text { (m) }\end{array}$ & $\begin{array}{c}\text { DBH } \\
(\mathrm{cm})\end{array}$ & Biomass (kg) \\
\hline 4 & Red Oak & HW & 19.23 & 31.16 & 544.33 \\
\hline 5 & Red Oak & HW & 21.07 & 26.16 & 419.03 \\
\hline 7 & Red Oak & HW & 18.99 & 21.68 & 259.95 \\
\hline 10 & Sugar Maple & HW & 14.36 & 18.91 & 140.52 \\
\hline 11 & Sugar Maple & HW & 17.98 & 25.58 & 323.94 \\
\hline 13 & Sugar Maple & HW & 17.96 & 20.27 & 201.96 \\
\hline 14 & White Birch & HW & 19.00 & 25.17 & 301.95 \\
\hline 15 & Red Oak & HW & 21.50 & 23.30 & 336.69 \\
\hline 16 & Aspen & HW & 19.01 & 22.48 & 173.27 \\
\hline 17 & Sugar Maple & HW & 19.22 & 19.96 & 210.71 \\
\hline 18 & White Birch & HW & 29.94 & 41.33 & 1165.56 \\
\hline 27 & Red Oak & HW & 22.23 & 33.03 & 694.14 \\
\hline 28 & Red Oak & HW & 21.13 & 23.19 & 328.67 \\
\hline 30 & Red Oak & HW & 18.92 & 30.26 & 507.01 \\
\hline 31 & Red Oak & HW & 17.44 & 25.71 & 341.21 \\
\hline 47 & Sugar Maple & HW & 19.55 & 31.90 & 538.97 \\
\hline 49 & Sugar Maple & HW & 20.50 & 31.95 & 565.67 \\
\hline 51 & Sugar Maple & HW & 21.08 & 35.83 & 724.49 \\
\hline 53 & Sugar Maple & HW & 20.71 & 31.38 & 552.53 \\
\hline 55 & Sugar Maple & HW & 17.48 & 28.03 & 375.96 \\
\hline 73 & Sugar Maple & HW & 19.18 & 28.21 & 417.85 \\
\hline 74 & Sugar Maple & HW & 20.23 & 36.71 & 729.33 \\
\hline 75 & Sugar Maple & HW & 20.03 & 36.34 & 708.76 \\
\hline 76 & Sugar Maple & HW & 18.73 & 28.48 & 414.67 \\
\hline 77 & Sugar Maple & HW & 17.87 & 29.37 & 422.46 \\
\hline
\end{tabular}




$\begin{array}{cccccc}82 & \text { Sugar Maple } & \text { HW } & 18.35 & 38.84 & 740.75 \\ 83 & \text { Red Oak } & \text { HW } & 20.82 & 22.38 & 300.24 \\ 92 & \text { Yellow Birch } & \text { HW } & 17.93 & 24.58 & 273.10 \\ 96 & \text { Sugar Maple } & \text { HW } & 19.51 & 27.38 & 400.00 \\ 100 & \text { Yellow Birch } & \text { HW } & 15.87 & 33.51 & 461.26 \\ 104 & \text { Sugar Maple } & \text { HW } & 19.23 & 37.25 & 716.01 \\ 105 & \text { Sugar Maple } & \text { HW } & 18.35 & 34.40 & 586.21 \\ 107 & \text { Sugar Maple } & \text { HW } & 23.83 & 39.33 & 971.92 \\ 109 & \text { Sugar Maple } & \text { HW } & 20.50 & 35.80 & 705.38 \\ 1 & \text { Red Pine } & \text { SW } & 22.57 & 26.05 & 302.52 \\ 2 & \text { Red Pine } & \text { SW } & 24.46 & 36.65 & 640.15 \\ & & & & & \\ 3 & \text { White Pine } & \text { SW } & 24.14 & 33.17 & 420.95 \\ 6 & \text { Eastern Hemlock } & \text { SW } & 23.58 & 32.76 & 463.45 \\ 8 & \text { Red Pine } & \text { SW } & 26.40 & 32.91 & 555.17 \\ 9 & \text { White Pine } & \text { SW } & 17.96 & 20.83 & 128.93 \\ 12 & \text { Red Pine } & \text { SW } & 19.00 & 27.79 & 296.24 \\ 19 & \text { Red Pine } & \text { SW } & 27.65 & 38.45 & 784.37 \\ 20 & \text { White Pine } & \text { SW } & 17.99 & 22.90 & 157.63 \\ 21 & \text { Red Pine } & \text { SW } & 30.20 & 43.51 & 1081.61 \\ 22 & \text { White Pine } & \text { SW } & 28.50 & 41.88 & 765.05 \\ 23 & \text { White Pine } & \text { SW } & 22.15 & 40.16 & 574.41 \\ 24 & \text { Red Pine } & \text { SW } & 24.49 & 29.66 & 422.52 \\ 25 & \text { Red Pine } & \text { SW } & 22.54 & 31.99 & 454.15 \\ 26 & \text { Red Pine } & \text { SW } & 24.48 & 21.06 & 211.12 \\ 29 & \text { Red Pine } & \text { SW } & 15.93 & 25.08 & 205.02 \\ 32 & \text { Red Pine } & \text { SW } & 17.04 & 41.40 & 585.60 \\ 106 & \text { Eastern Hemlock } & \text { SW } & 19.55 & 29.97 & 326.83\end{array}$


Table 41. Estimated 2017 Biomass; 2011 Equation Tested on 2017 Dataset

\begin{tabular}{|c|c|c|c|c|c|}
\hline Tree ID & Species & Wood & $\begin{array}{c}\text { Height } \\
\text { (m) }\end{array}$ & $\begin{array}{c}\text { DBH } \\
(\mathrm{cm})\end{array}$ & Biomass (kg) \\
\hline 4 & Red Oak & HW & 20.69 & 31.16 & 581.31 \\
\hline 5 & Red Oak & HW & 18.17 & 21.98 & 259.15 \\
\hline 7 & Red Oak & HW & 19.17 & 28.34 & 450.76 \\
\hline 10 & Sugar Maple & HW & 16.99 & 11.75 & 45.27 \\
\hline 11 & Sugar Maple & HW & 20.88 & 29.28 & 486.93 \\
\hline 13 & Sugar Maple & HW & 19.67 & 26.93 & 391.13 \\
\hline 14 & White Birch & HW & 23.97 & 31.99 & 588.26 \\
\hline 15 & Red Oak & HW & 20.87 & 27.92 & 470.73 \\
\hline 16 & Aspen & HW & 20.87 & 27.74 & 285.58 \\
\hline 17 & Sugar Maple & HW & 20.89 & 26.56 & 402.15 \\
\hline 18 & White Birch & HW & 31.36 & 44.12 & 1375.22 \\
\hline 27 & Red Oak & HW & 22.17 & 32.66 & 676.92 \\
\hline 28 & Red Oak & HW & 22.46 & 30.15 & 586.97 \\
\hline 30 & Red Oak & HW & 19.31 & 33.41 & 627.63 \\
\hline 31 & Red Oak & HW & 16.51 & 26.75 & 352.30 \\
\hline 47 & Sugar Maple & HW & 19.42 & 38.12 & 754.38 \\
\hline 49 & Sugar Maple & HW & 20.87 & 41.61 & 956.03 \\
\hline 51 & Sugar Maple & HW & 22.06 & 45.26 & 1185.11 \\
\hline 53 & Sugar Maple & HW & 20.64 & 34.07 & 644.96 \\
\hline 55 & Sugar Maple & HW & 19.20 & 33.35 & 576.65 \\
\hline 73 & Sugar Maple & HW & 18.69 & 32.81 & 544.03 \\
\hline 74 & Sugar Maple & HW & 19.51 & 35.63 & 665.01 \\
\hline 75 & Sugar Maple & HW & 19.60 & 32.53 & 561.74 \\
\hline 76 & Sugar Maple & HW & 20.42 & 37.54 & 770.16 \\
\hline 77 & Sugar Maple & HW & 20.29 & 32.52 & 581.22 \\
\hline 82 & Sugar Maple & HW & 18.21 & 37.91 & 702.51 \\
\hline 83 & Red Oak & HW & 21.46 & 28.96 & 521.30 \\
\hline 92 & Yellow Birch & HW & 18.51 & 28.31 & 367.51 \\
\hline 96 & Sugar Maple & HW & 21.77 & 32.09 & 604.29 \\
\hline 100 & Yellow Birch & HW & 15.36 & 36.06 & 520.22 \\
\hline 104 & Sugar Maple & HW & 20.66 & 36.00 & 716.82 \\
\hline 105 & Sugar Maple & HW & 18.45 & 35.64 & 631.36 \\
\hline 107 & Sugar Maple & HW & 24.10 & 41.76 & 1101.53 \\
\hline 109 & Sugar Maple & HW & 22.27 & 50.69 & 1485.36 \\
\hline
\end{tabular}




$\begin{array}{lccccc}1 & \text { Red Pine } & \text { SW } & 20.25 & 26.90 & 293.46 \\ 2 & \text { Red Pine } & \text { SW } & 25.78 & 35.01 & 613.29 \\ 3 & \text { White Pine } & \text { SW } & 24.18 & 35.65 & 486.32 \\ 6 & \text { Eastern Hemlock } & \text { SW } & 26.45 & 37.51 & 678.05 \\ 8 & \text { Red Pine } & \text { SW } & 27.47 & 41.50 & 905.53 \\ 9 & \text { White Pine } & \text { SW } & 20.29 & 20.79 & 139.95 \\ 12 & \text { Red Pine } & \text { SW } & 19.51 & 25.18 & 249.00 \\ 19 & \text { Red Pine } & \text { SW } & 29.62 & 43.54 & 1065.13 \\ 20 & \text { White Pine } & \text { SW } & 18.18 & 32.25 & 319.23 \\ 21 & \text { Red Pine } & \text { SW } & 31.35 & 46.08 & 1251.74 \\ 22 & \text { White Pine } & \text { SW } & 28.48 & 47.95 & 999.82 \\ 23 & \text { White Pine } & \text { SW } & 16.14 & 45.47 & 573.08 \\ 24 & \text { Red Pine } & \text { SW } & 27.27 & 32.73 & 563.67 \\ 25 & \text { Red Pine } & \text { SW } & 23.82 & 32.53 & 493.79 \\ 26 & \text { Red Pine } & \text { SW } & 24.24 & 29.59 & 415.87 \\ 29 & \text { Red Pine } & \text { SW } & 17.92 & 33.40 & 403.15 \\ 32 & \text { Red Pine } & \text { SW } & 19.14 & 45.62 & 787.15 \\ 106 & \text { Eastern Hemlock } & \text { SW } & 22.31 & 29.97 & 367.47\end{array}$

\subsection{6-year time period growth amount}

Table 42. Volume Growth of Single Trees between 2011 and 2017

\begin{tabular}{ccccc}
\hline Tree ID & Species & $\begin{array}{c}\text { Merchantable } \\
\text { Volume }\left(\mathbf{m}^{\mathbf{3}}\right)\end{array}$ & $\begin{array}{c}\text { Merchantable } \\
\text { Volume }\left(\mathbf{m}^{\mathbf{3}}\right)\end{array}$ & $\begin{array}{c}\text { Increment } \\
\left.\mathbf{( m}^{\mathbf{3}}\right)\end{array}$ \\
\hline 4 & Red Oak & 0.87 & 0.61 & 0.26 \\
5 & Red Oak & 0.00 & 0.00 & 0.00 \\
7 & Red Oak & 0.26 & 0.00 & 0.26 \\
10 & Sugar Maple & 0.00 & 0.00 & 0.00 \\
11 & Sugar Maple & 0.00 & 0.00 & 0.00 \\
13 & Sugar Maple & 0.00 & 0.00 & 0.00 \\
14 & White Birch & 0.00 & 0.00 & 0.00 \\
15 & Red Oak & 0.00 & 0.00 & 0.00 \\
16 & Aspen & 0.00 & 0.00 & 0.00 \\
17 & Sugar Maple & 0.00 & 0.00 & 0.00 \\
18 & White Birch & 3.02 & 2.06 & 0.96 \\
27 & Red Oak & 0.57 & 0.48 & 0.08
\end{tabular}




\begin{tabular}{|c|c|c|c|c|}
\hline 28 & Red Oak & 0.88 & 0.60 & 0.28 \\
\hline 30 & Red Oak & 0.61 & 0.55 & 0.06 \\
\hline 31 & Red Oak & 0.16 & 0.00 & 0.16 \\
\hline 47 & Sugar Maple & 0.30 & 0.00 & 0.30 \\
\hline 49 & Sugar Maple & 0.57 & 0.30 & 0.27 \\
\hline 51 & Sugar Maple & 1.02 & 0.82 & 0.21 \\
\hline 53 & Sugar Maple & 0.55 & 0.31 & 0.24 \\
\hline 55 & Sugar Maple & 0.36 & 0.16 & 0.20 \\
\hline 73 & Sugar Maple & 0.54 & 0.31 & 0.24 \\
\hline 74 & Sugar Maple & 0.29 & 0.00 & 0.29 \\
\hline 75 & Sugar Maple & 0.32 & 0.00 & 0.32 \\
\hline 76 & Sugar Maple & 0.50 & 0.31 & 0.18 \\
\hline 77 & Sugar Maple & 0.48 & 0.31 & 0.17 \\
\hline 82 & Sugar Maple & 0.35 & 0.00 & 0.35 \\
\hline 83 & Red Oak & 0.80 & 0.54 & 0.25 \\
\hline 92 & Yellow Birch & 0.35 & 0.29 & 0.06 \\
\hline 96 & Sugar Maple & 0.51 & 0.28 & 0.23 \\
\hline 100 & Yellow Birch & 0.85 & 0.65 & 0.20 \\
\hline 104 & Sugar Maple & 0.14 & 0.00 & 0.14 \\
\hline 105 & Sugar Maple & 0.59 & 0.38 & 0.22 \\
\hline 107 & Sugar Maple & 1.30 & 0.92 & 0.37 \\
\hline 109 & Sugar Maple & 1.43 & 1.10 & 0.33 \\
\hline 1 & Red Pine & 0.57 & 0.60 & -0.03 \\
\hline 2 & Red Pine & 0.53 & 0.36 & 0.17 \\
\hline 3 & White Pine & 0.96 & 0.94 & 0.02 \\
\hline 6 & Eastern Hemlock & 0.92 & 0.00 & 0.92 \\
\hline 8 & Red Pine & 0.53 & 0.44 & 0.09 \\
\hline 9 & White Pine & 0.18 & 0.22 & -0.04 \\
\hline 12 & Red Pine & 0.44 & 0.27 & 0.17 \\
\hline 19 & Red Pine & 1.16 & 0.92 & 0.24 \\
\hline 20 & White Pine & 0.22 & 0.00 & 0.22 \\
\hline 21 & Red Pine & 1.29 & 1.08 & 0.20 \\
\hline 22 & White Pine & 1.75 & 1.09 & 0.65 \\
\hline 23 & White Pine & 0.58 & 0.67 & -0.08 \\
\hline 24 & Red Pine & 1.76 & 1.26 & 0.50 \\
\hline 25 & Red Pine & 1.00 & 0.81 & 0.19 \\
\hline 26 & Red Pine & 0.96 & 0.72 & 0.24 \\
\hline 29 & Red Pine & 0.29 & 0.17 & 0.12 \\
\hline 32 & Red Pine & 0.51 & 0.27 & 0.24 \\
\hline 106 & Eastern Hemlock & 2.35 & 1.74 & 0.61 \\
\hline
\end{tabular}


Table 43. Dry Biomass Growth of Single Trees between 2011 and 2017

\begin{tabular}{|c|c|c|c|c|}
\hline Tree ID & Species & $\begin{array}{c}\text { Biomass } \\
\text { (kg) } 2017\end{array}$ & $\begin{array}{c}\text { Biomass } \\
\text { (kg) } 2011\end{array}$ & $\begin{array}{c}\text { Increment } \\
(\mathrm{kg})\end{array}$ \\
\hline 4 & Red Oak & 988.35 & 816.53 & 171.82 \\
\hline 5 & Red Oak & 299.68 & 274.92 & 24.76 \\
\hline 7 & Red Oak & 480.52 & 398.49 & 82.03 \\
\hline 10 & Sugar Maple & 42.29 & 10.52 & 31.77 \\
\hline 11 & Sugar Maple & 383.78 & 254.23 & 129.54 \\
\hline 13 & Sugar Maple & 99.19 & 22.22 & 76.97 \\
\hline 14 & White Birch & 256.90 & 124.69 & 132.21 \\
\hline 15 & Red Oak & 330.93 & 192.18 & 138.75 \\
\hline 16 & Aspen & 78.47 & 28.79 & 49.68 \\
\hline 17 & Sugar Maple & 143.58 & 91.22 & 52.36 \\
\hline 18 & White Birch & 2427.89 & 1764.76 & 663.13 \\
\hline 27 & Red Oak & 835.02 & 718.60 & 116.42 \\
\hline 28 & Red Oak & 1076.73 & 849.68 & 227.04 \\
\hline 30 & Red Oak & 799.74 & 706.96 & 92.77 \\
\hline 31 & Red Oak & 441.31 & 391.03 & 50.28 \\
\hline 47 & Sugar Maple & 497.90 & 372.49 & 125.42 \\
\hline 49 & Sugar Maple & 726.24 & 522.71 & 203.53 \\
\hline 51 & Sugar Maple & 1142.99 & 883.20 & 259.79 \\
\hline 53 & Sugar Maple & 701.20 & 550.30 & 150.91 \\
\hline 55 & Sugar Maple & 583.48 & 410.26 & 173.22 \\
\hline 73 & Sugar Maple & 627.37 & 508.96 & 118.41 \\
\hline 74 & Sugar Maple & 493.64 & 382.82 & 110.82 \\
\hline 75 & Sugar Maple & 536.92 & 423.86 & 113.06 \\
\hline 76 & Sugar Maple & 628.81 & 505.79 & 123.02 \\
\hline 77 & Sugar Maple & 605.93 & 481.49 & 124.45 \\
\hline 82 & Sugar Maple & 545.34 & 375.13 & 170.21 \\
\hline 83 & Red Oak & 937.30 & 759.51 & 177.79 \\
\hline 92 & Yellow Birch & 511.70 & 423.03 & 88.67 \\
\hline 96 & Sugar Maple & 685.41 & 473.16 & 212.25 \\
\hline 100 & Yellow Birch & 811.05 & 645.89 & 165.16 \\
\hline 104 & Sugar Maple & 440.94 & 321.09 & 119.85 \\
\hline 105 & Sugar Maple & 671.66 & 588.53 & 83.13 \\
\hline 107 & Sugar Maple & 1325.22 & 1116.46 & 208.77 \\
\hline 109 & Sugar Maple & 1351.12 & 1143.33 & 207.79 \\
\hline 1 & Red Pine & 440.06 & 429.79 & 10.27 \\
\hline 2 & Red Pine & 429.61 & 332.70 & 96.91 \\
\hline
\end{tabular}




$\begin{array}{ccccc}3 & \text { White Pine } & 646.31 & 550.06 & 96.25 \\ 6 & \text { Eastern Hemlock } & 653.49 & 183.65 & 469.83 \\ 8 & \text { Red Pine } & 454.78 & 366.15 & 88.63 \\ 9 & \text { White Pine } & 197.32 & 216.17 & -18.86 \\ 12 & \text { Red Pine } & 333.95 & 250.42 & 83.53 \\ 19 & \text { Red Pine } & 863.15 & 690.46 & 172.69 \\ 20 & \text { White Pine } & 217.76 & 133.48 & 84.28 \\ 21 & \text { Red Pine } & 919.12 & 789.01 & 130.10 \\ 22 & \text { White Pine } & 1044.04 & 732.52 & 311.52 \\ 23 & \text { White Pine } & 425.24 & 435.09 & -9.85 \\ 24 & \text { Red Pine } & 1210.29 & 882.71 & 327.58 \\ 25 & \text { Red Pine } & 683.51 & 580.77 & 102.74 \\ 26 & \text { Red Pine } & 640.00 & 554.19 & 85.81 \\ 29 & \text { Red Pine } & 258.19 & 193.52 & 64.67 \\ 32 & \text { Red Pine } & 374.48 & 228.39 & 146.09 \\ 106 & \text { Eastern Hemlock } & 1463.99 & 1107.67 & 356.32\end{array}$




\section{Appendix D}

The only copyright needed material is in Figure 19. LiDAR data acquisition path on study area in 2017, Image courtesy of Quantum Spatial, Inc. and the screen capture of the email that illustrates I have permission to use it.

$10 / 10 / 2018$

Michigan Technological University Mail - copyright permission request

Michigan Tech

Tugay Demiraslan <tdemiras@mtu.edu>

\section{copyright permission request}

Quantum Spatial Archive <archive@quantumspatial.com>

Fri, Jun 22, 2018 at 10:32 AM

To: Tugay Demiraslan <tdemiras@mtu.edu>

Hi Tugay,

You can use images from this data report. Please include a caption that says "Image courtesy of Quantum Spatial, Inc."

Best regards,

Sabrina

On Tue, Jun 19, 2018 at 10:08 AM, Tugay Demiraslan <tdemiras@mtu.edu> wrote

Hello Sabrina,

I'm a graduate student at Michigan Tech University Forestry Department, and I intend to use the figure at the bottom of

Page 9 on the attached document in my Master's Thesis. To be avoid any plagiarism issue, I need a written

permission from you. Please let me know. Thank you.

Best regards,

Tugay Demiraslan

Tugay Demiraslan

President of Turkish Student Association

MS, Forest Ecology and Management

School of Forest Resources \& Environmental Science

Michigan Technological University

Office 135

tdemiras@mtu.edu

906-275-8662 